\title{
EFICIÊNCIA AGRONÔMICA DE FONTES NITROGENADAS E DE ASSOCIAÇÕES DE FERTILIZANTES NO PROCESSO DE DIFERIMENTO DE Brachiaria brizantha cv Marandu
}

\author{
Miguel José Thomé Menezes
}

Dissertação apresentada à Escola Superior de Agricultura "Luiz de Queiroz", Universidade de São Paulo, para obtenção do título de Mestre em Agronomia, Área de Concentração: Ciência Animal e Pastagens.

P I R A C I C A B A

Estado de São Paulo - Brasil

Setembro - 2004 


\title{
EFICIÊNCIA AGRONÔMICA DE FONTES NITROGENADAS E DE ASSOCIAÇÕES DE FERTILIZANTES NO PROCESSO DE DIFERIMENTO DE Brachiaria brizantha cv Marandu
}

\author{
Miguel José Thomé Menezes \\ Engenheiro Agrônomo
}

Orientador: Prof. Dr. MOACYR CORSI

Dissertação apresentada à Escola Superior de Agricultura "Luiz de Queiroz", Universidade de São Paulo, para obtenção do título de Mestre em Agronomia, Área de Concentração: Ciência Animal e Pastagens.

P I R A C I C A B A

Estado de São Paulo - Brasil

Setembro - 2004 


\section{Dados Internacionais de Catalogação na Publicação (CIP) DIVISÃO DE BIBLIOTECA E DOCUMENTAÇÃO - ESALQ/USP}

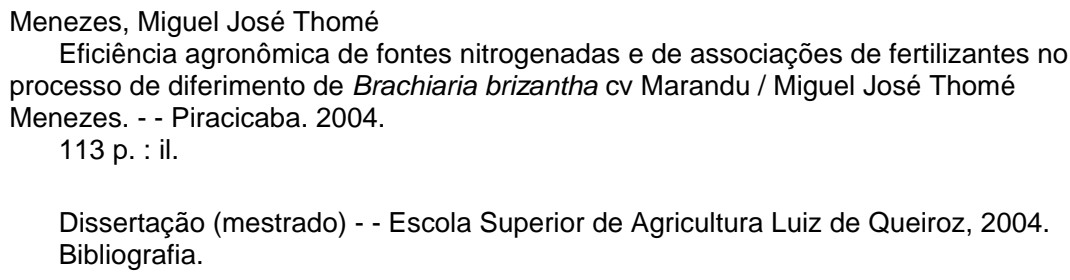

1. Brachiaria 2. Capim marandu 3. Crescimento vegetal 4. Fertilizantes nitrogenados 5. Pastejo I. Título

CDD 633.2 
A Luiz Vicente de Souza Queiroz, que através da doação de tua vida, e de teu trabalho construíste a grandeza da ESALQ...

A gratidão e homenagem do que dela é filho e se orgulha 


\section{AGRADECIMENTOS}

- Aos meus pais Manoel Pedro e Maria Aparecida, e aos meus irmãos Manoel Pedro e Maria Luiza, pela inexaurível dedicação, e pelo imensurável incentivo e carinho, meu eterno agradecimento.

- O meu grande agradecimento ao Prof. Moacyr Corsi, pela amizade e pelo inestimável papel na minha formação profissional e como indivíduo, através do exemplo de trabalho, seriedade, ética e constante aprendizado.

- À Dra. Patrícia Menezes Santos, pela paciência e orientação da condução deste trabalho.

- À Thaís Regina Drezza, pelo constante apoio, e pelo exemplo de companheirismo e dedicação.

- À Escola Superior de Agricultura "Luiz de Queiroz", em especial o Departamento de Zootecnia, pela insigne formação acadêmica.

- À EMBRAPA Pecuária Sudeste, pela concessão da área experimental onde foi realizado este trabalho, do alojamento e das estufas onde foram secadas as amostras.

- Ao Conselho Nacional de Desenvolvimento Científico e Tecnológico, CNPq, pela concessão da bolsa de estudos.

- Aos Eng. Agr. Geraldo Bueno Martha Júnior, Marco Antonio Alvares Balsalobre, Marco Antonio Penati e Daniel Silva Pagotto, pela amizade e orientação enquanto estagiário, período indispensável para o estímulo do meu interesse pela pesquisa.

- Aos grandes amigos Fábio Luiz Aires Maya, Miguel da Rocha Cavalcanti, Roberto Naves Souza Aguiar, pela longa convivência, sempre harmônica e 
estimulante.

- Ao Prof. Dr. Godofredo César Vitti, pela sincera amizade e pela contribuição ao meu desenvolvimento pessoal e profissional.

- Ao Dr. Fábio Prudêncio de Campos e à Dra. Carla Maris Bittar Nussio, pela amizade e auxílio na execução das análises laboratoriais.

- A todos os estagiários do Projeto CAPIM, pela indispensável contribuição para que esse trabalho se tornasse uma realidade.

- Aos funcionários e estagiários da EMBRAPA Pecuária Sudeste.

- À R.P.D. Lesma Lerda, pelos ensinamentos e contribuições indispensáveis á minha formação, e pelas lembranças que ficarão para sempre.

- Ao Dr. Cláudio Manoel Rodrigues de Melo, pelo auxílio na execução das análises estatísticas.

- Ao grupo de estudos em plantas forrageiras, GEPF, na pessoa de seu coordenador, Prof. Dr. Sila Carneiro da Silva, pelo empréstimo de materiais indispensáveis à realização desse trabalho.

- À todos que, de alguma forma, contribuíram para o bom andamento e conclusão desse trabalho. 


\section{SUMÁRIO}

Página

LISTA DE FIGURAS .......................................................................... viii

LISTA DE TABELAS ........................................................................

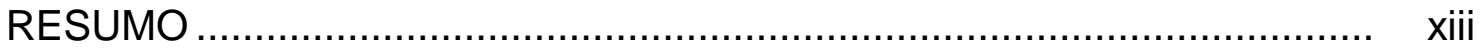

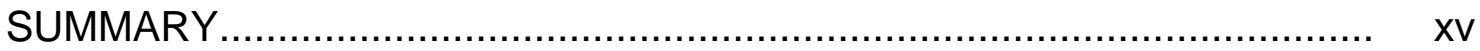

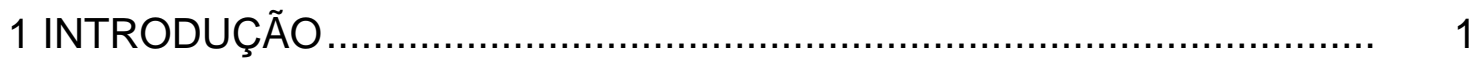

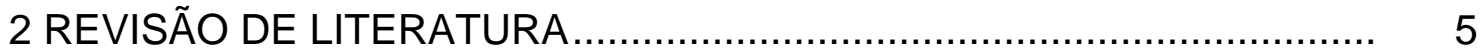

2.1 Estacionalidade de Produção da Planta Forrageira .............................. 5

2.1.1 Influência dos fatores climáticos sobre a produção das pastagens..... 7

2.1.2 Quantificação da estacionalidade de produção das pastagens ao

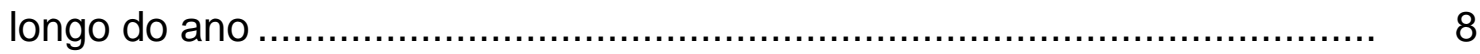

2.1.3 Índices climáticos utilizados para previsão de produtividade ............. 10

2.2 Alternativas para minimizar a produção estacional de forragem............ 12

2.3 Diferimento de pastagens .......................................................... 13

2.3.1 Escolha da espécie forrageira.................................................. 14

2.3.2 Épocas de diferimento e utilização da pastagem ................................. 15

2.3.3 Acúmulo de forragem em áreas diferidas ..................................... 18

2.3.4 Valor nutritivo da forragem em pastagens diferidas .......................... 23

2.3.4.1 Valor nutritivo da dieta selecionada pelo animal ........................... 28

2.3.5 Adubação de áreas diferidas no momento da vedação ..................... 32

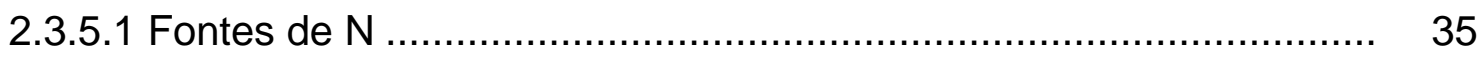

2.3.5.2 Vias de perdas do $\mathrm{N}$ aplicado via fertilizante no sistema soloplanta. 
2.3.5.3 Fatores que influenciam as perdas de $\mathrm{N}$ por volatilização .............. 39

2.3.5.4 Alternativas $\mathrm{p} /$ redução das perdas de $\mathrm{N}-\mathrm{NH}_{3}$ por volatilização ....... 42

2.4 Recuperação do nitrogênio aplicado.................................................... 44

3 MATERIAL E MÉTODOS .......................................................... 47

3.1 Localização e Clima da área experimental ........................................ 47

3.2 Delineamento experimental e tratamentos ....................................... 49

3.3 Instalação e condução do experimento .......................................... 50

3.4 Respostas medidas ...................................................................... 52

3.4.1 Determinações no campo ................................................... 52

3.4.1.1 Massa de forragem (Prod, PI, R1, R2, RI e Rebrota) .................. 52

3.4.1.2 Modelagem das respostas produtivas através de índices

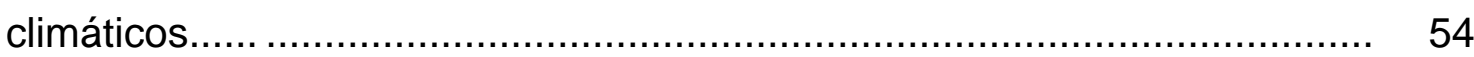

3.4.1.3 Densidade volumétrica da forragem ...................................... 55

3.4.1.4 Perdas pós-pastejo …....................................................... 55

3.4.1.5 Simulação de Pastejo .................................................................. 56

3.4.1.6 Recuperação aparente do nitrogênio aplicado.............................. 57

3.4.2 Determinações químico-bromatológicas ........................................ 57

3.5 Análise estatística dos dados.......................................................... 59

4 RESULTADOS E DISCUSSÃO ........................................................... 61

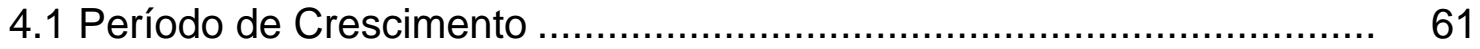

4.1.1 Acúmulo de forragem ........................................................... 61

4.1.2 Recuperação Aparente do nitrogênio aplicado ................................. 72

4.2 Período de Pastejo ................................................................. 76

4.2.1 Parâmetros Produtivos ........................................................... 76

4.2.2 Valor nutritivo da forragem ofertada e dos pastejos simulados.......... 81

4.3 Período de Rebrota ......................................................................... 91

5 CONCLUSÕES .................................................................... 95

REFERÊNCIAS BIBLIOGRÁFICAS..................................................... 97 


\section{LISTA DE FIGURAS}

Página

1 Variação mensal da radiação solar ao longo do ano em PiracicabaSP (período de 1994 a 2003) e Brasília-DF (período de 1971 a 2002)

2 Variação mensal da temperatura média ao longo do ano em diferentes localidades do Brasil....

3 Variação mensal da precipitação pluvial em diferentes localidades ao longo do ano.

4 Acúmulo de hastes e folhas e senescência de folhas em função da interceptação luminosa pelo dossel forrageiro de capim mombaça em lotação rotacionada.

19

5 Fracionamento da composição botânica da forragem disponível (A) e da dieta ingerida pelo animal (B) ao longo do ano.

6 Consumo anual de uréia, sulfato de amônio e nitrato de amônio no Brasil durante a década de 90

7 Precipitação e temperatura máxima e mínima mensal na fazenda Canchim, EMBRAPA CPPSE (média do período de 1992 a 2003)

8 Precipitação e temperatura máxima e mínima mensal na fazenda Canchim, EMBRAPA CPPSE durante o ano experimental (2003)..

9 Caracterização visual do resíduo de forragem nas parcelas após 9 semanas de pastejo (Resíduo 2) 
10 Croqui da área experimental com destaque para os métodos de avaliação das MF e Perdas.

11 Imagem da parcela com material a ser coletado dentro das gaiolas após os primeiros pastejos..................................................... 56

12 Relação folha:haste média dos seis tratamentos ao longo do

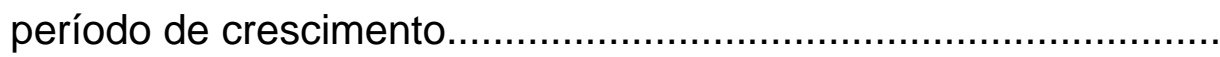

13 Acúmulo de forragem total, forragem verde, lâminas de folhas verdes e forragem digestível média dos diferentes tratamentos durante o período de crescimento.

14 Acúmulo de forragem total, forragem verde e lâminas de folhas verdes médio dos diferentes tratamentos em função dos GD acumulados durante o período de crescimento

15 Acúmulo de forragem total, forragem verde e lâminas de folhas verdes médio dos diferentes tratamentos em função das UF acumulados durante o período de crescimento

16 Recuperação aparente do nitrogênio aplicado via fertilizante ao longo do período de crescimento para os diferentes tratamentos

17 Massa de forragem total, forragem verde e altura da pastagem ao longo do período de pastejo

18 Densidade volumétrica da forragem total e verde ao longo do período de pastejo

19 Perdas por pastejo, em valores absolutos e relativos, ao longo do período de pastejo.

20 Composição química e digestibilidade da forragem ofertada nos diferentes tratamentos e da média dos pastejos simulados ao longo do período de pastejo

21 Teor de lignina da simulação de pastejo nos diferentes tratamentos e da média das massas de forragem ao longo do período de pastejo 
22 Massa de forragem total, forragem verde, forragem digestível e recuperação aparente do nitrogênio aplicado no decorrer do

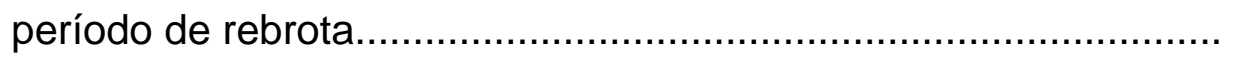




\section{LISTA DE TABELAS}

Página

1 Produção anual e variação estacional de acúmulo de forragem para diferentes espécies forrageiras.............................................. 9

2 Massa de forragem máxima e mínima em pastagens diferidas, no momento da utilização............................................................... 20

3 Composição químico-bromatológica e digestibilidade máxima e mínima em pastagens diferidas, no momento da utilização.............

4 Composição botânica da forragem ofertada e da dieta selecionada em pastagens de $B$. humidicola ao longo do ano.......................... $\quad 29$

5 Características agronômicas das fontes de nitrogênio encontradas no mercado.

6 Características agronômicas das fontes de nitrogênio encontradas no mercado.

7 Adubações realizadas nas parcelas em março de 2003

8 Massa total de forragem seca durante o período de crescimento nos seis tratamentos testados.

9 Massa de forragem verde durante o período de crescimento nos seis tratamentos testados.

10 Massa de lâminas de folhas verdes durante o período de crescimento nos seis tratamentos testados.

11 Massa de forragem digestível durante o período de crescimento nos seis tratamentos testados. 
12 Taxa média de acúmulo de forragem dos seis tratamentos ao longo do período de crescimento.

13 Recuperação aparente do nitrogênio aplicado via fertilizante ao

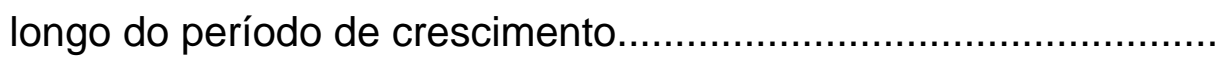

14 Equações utilizadas para gerar as curvas de recuperação aparente

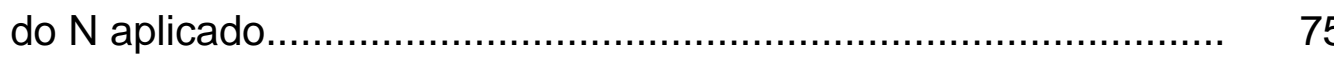

15 Parâmetros produtivos médios dos seis tratamentos testados ao longo do período de pastejo................................................... 76

16 Nutrientes digestíveis totais dos pastejos simulados para os diferentes tratamentos ao longo do período de pastejo.................. 81

17 Teor de PB da forragem ofertada nos diferentes tratamentos e da média dos pastejos simulados ao longo do período de pastejo......

18 Teor de FDN da forragem ofertada nos diferentes tratamentos e da média dos pastejos simulados ao longo do período de pastejo......

19 Teor de FDA da forragem ofertada nos diferentes tratamentos e da média dos pastejos simulados ao longo do período de pastejo......

20 Teor de lignina da forragem ofertada nos diferentes tratamentos e da média dos pastejos simulados ao longo do período de pastejo.

21 DIVMS da forragem ofertada nos diferentes tratamentos e da média dos pastejos simulados ao longo do período de pastejo......

22 Equações utilizadas para gerar as curvas de composição química e digestibilidade das amostras de forragem ofertada e pastejos simulados

23 Parâmetros produtivos médios dos seis tratamentos testados ao longo do período de rebrota

24 Teor de proteína bruta nos diferentes tratamentos ao longo do período de rebrota 


\title{
EFICIÊNCIA AGRONÔMICA DE FONTES DE NITROGÊNIO E DE ASSOCIAÇÕES DE FERTILIZANTES NO DIFERIMENTO DE PASTAGENS DE Brachiaria brizantha cv Marandu
}

\author{
Autor: MIGUEL JOSÉ THOMÉ MENEZES \\ Orientador: Prof. Dr. MOACYR CORSI
}

\section{RESUMO}

Para avaliar a eficiência do uso de diferentes fontes nitrogenadas e associações de fertilizantes aplicadas no momento do diferimento de $B$. brizantha cv. Marandu sobre a produção de forragem e recuperação aparente do nitrogênio aplicado nos períodos de crescimento, pastejo e rebrota, além do valor nutritivo da forragem pastejada e das perdas por pastejo, foi realizada essa pesquisa, entre março e novembro de 2003. O delineamento foi em blocos completos ao acaso, com quatro repetições, sendo a dose de $\mathrm{N}$ aplicada de 50 $\mathrm{kg} \cdot \mathrm{ha}^{-1}$. Os seis tratamentos foram: testemunha $\left(0 \mathrm{~kg} . \mathrm{N} \cdot \mathrm{ha}^{-1}\right)$, uréia, sulfato de amônio, uréia associada ao sulfato de amônio, uréia associada ao cloreto de potássio e uréia associada ao superfosfato simples. Durante o período de crescimento, entre março e julho, não houve diferenças entre tratamentos na produção de forragem aos 104 dias de vedação da planta indicando que estudos que objetivam a aplicação de associações de fertilizantes devem ter 
controle sobre a uniformidade da distribuição, por essa representar fonte de variação desconhecida. Os valores médios nesse momento foram de 6000 , 2700 e $1100 \mathrm{~kg}$ ha $^{-1}$ de MS, MSV e LFV, respectivamente, sendo a taxa média de acúmulo de forragem de 26,1 kg MS.ha- ${ }^{-1} \cdot \mathrm{dia}^{-1}$. As máximas produções de MS, MSV e LFV ocorreram aos 77, 63 e 63 dias, aos 421, 328 e 429 GD e às 3855, 2709 e 3033 UF respectivamente, indicando que áreas diferidas adubadas devem ser utilizadas na primeira metade do período seco. O uso de GD e UF não apresentaram vantagens em relação à avaliação diária. A recuperação média do $\mathrm{N}$ aos 104 dias foi de 11,6\%. No período de pastejo, entre julho e setembro, as reduções na MSV foram mais aceleradas que as de MS total. A altura da planta decresceu mais lentamente que a MS, principalmente devido à presença de hastes. Isso contribuiu para a definir a densidade volumétrica das folhas verdes como ferramenta indicada ao monitoramento da forragem diferida durante o pastejo. As perdas por pastejo

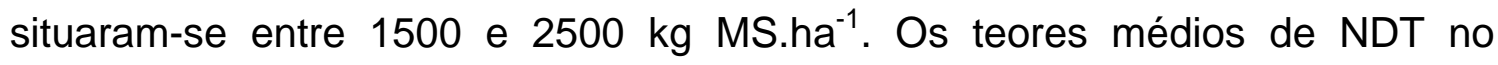
pastejo simulado foram $52,9 \%$ e $50,7 \%$ na primeira e quarta quinzenas de pastejo, respectivamente. O teor de PB acompanhou a mesma tendência, apresentando valores médios tanto para planta toda quanto para pastejo simulado no início e final desse período de $4,2 \%$ e 3,1\%, respectivamente. A DIVMS média da forragem colhida na simulação de pastejo foi superior a da forragem ofertada ao animal em pastejo, porém decrescente ao longo do período de pastejo. Os valores do pastejo simulado foram de $58 \%$ e $50,1 \%$ na segunda e oitava semanas de pastejo respectivamente. Não houve diferenças de produção de forragem entre os tratamentos durante a rebrota, porém a PB dos tratamentos adubados foi superior a da testemunha, o que resultou em recuperações do N crescentes ao longo das avaliações, atingindo 29\% aos 47 dias de crescimento, e indicando que houve efeito residual da adubação nitrogenada no momento do diferimento, sem no entanto reverter em aumentos de produção de forragem. 


\title{
AGRONOMIC EFFICIENCY OF NITROGEN SOURCES AND FERTILIZERS ASSOCIATIONS ON DEFERMENT PROCESS OF Brachiaria brizantha cv Marandu PASTURES
}

\author{
Author: MIGUEL JOSÉ THOMÉ MENEZES \\ Adviser: Prof. Dr. MOACYR CORSI
}

\section{SUMMARY}

The present research was conducted, from March through November 2003, to evaluate the efficiency of different nitrogen sources and fertilizers combinations on the deferment process of $B$. brizantha $\mathrm{cv}$. Marandu upon forage production and applied nitrogen recovery along the growing, grazing and regrowth phases, besides the grazed forage nutritive value and the grazing losses. A four repetition, randomized complete block design was used, and the nitrogen amount applied was $50 \mathrm{~kg} \mathrm{ha}^{-1}$ (with exception for the control treatment). The six treatments imposed were: control, urea, ammonium sulfate, urea associated with ammonium sulfate, urea associated with potassium chloride and urea associated with single superphosphate. During growing phase, from March to July, there were no production differences among treatments after 104 days of growing period, indicating that fertilizer associations experiments should evaluate application uniformity, because it represents 
unknown variation source. The total dry matter production (DM), green dry matter production (GDM) and green leaves blades (GLB) obtained was 6000 , 2700 and $1100 \mathrm{~kg}^{-h^{-1}}$, respectively. The maximum DM, GDM and GLB productions occurred at 77, 63 and 63 growing days; 421, 328 and 429 degreedays (DD); and 3855, 2709 and 3033 photothermal units (PU), respectively, indicating fertilized areas should be grazed at the end of autumn and beginning of winter. The DD and PU utilization weren't better than the daily evaluation. The nitrogen average recovery at 104 days of growing was $11.6 \%$. During grazing phase, from July trough September, GDM reductions occurred faster than DM. Plant height decreasing rhythm was slower than total DM, due to the stems. Therefore the green leaves volumetric density was chosen as the most appropriate monitoring tool of pasture during grazing. Losses values were located between 1500 and $2500 \mathrm{~kg} \mathrm{DM}$.ha ${ }^{-1}$. Simulated grazing TDN average fractions were $52.9 \%$ and $50.7 \%$ at second and eighth grazing weeks, respectively. CP fraction followed the same behavior, presenting simulated grazing and total offered forage average values of $4.2 \%$ and $3.1 \%$, in the beginning and end of grazing phase, respectively. Average IVDMD of grazing simulation harvested forage was superior when compared with animal offered forage, however it was decreasing along the grazing phase. Simulated grazing digestibility values were $58 \%$ and $50.1 \%$ at second and eighth weeks, respectively. There were no forage production differences during regrowth phase; however fertilized treatments CP were higher than the control treatment, resulting in increased nitrogen recoveries along the period, reaching 29\% with 47 growing days, and indicating there were residual fertilization effects. However, those effects weren't reverted in forage production increases. 


\section{INTRODUÇÃO}

O Brasil possui área de 850 milhões de ha, dos quais pouco mais de 350 milhões são ocupados por atividades agropecuárias (Instituto Brasileiro de Geografia e Estatística, 2004). Dentro dessa fração, as áreas de pastagem merecem destaque, por abrangerem quase 178 milhões de ha, onde se distribui a maior parte do rebanho bovino, composto por cerca de 185 milhões de cabeças.

Balsalobre et al. (2002) afirmaram que as taxas médias de lotação e desfrute nesse ambiente são de 0,8 UA.ha ${ }^{-1}$ e 16\%, respectivamente, retratando um perfil extensivo de exploração animal. Os resultados dos trabalhos de Tosi (1999) e de Maya (2003), onde as taxas de lotação médias ao longo do ano foram de 4,5 e 5,6 UA.ha ${ }^{-1}$. ano ${ }^{-1}$, demonstram que a média nacional situa-se de cinco a sete vezes abaixo dos valores potencialmente atingíveis. Esses autores também obtiveram produções de 675 e $855 \mathrm{~kg}$ de carcaça.ha $^{-1}$.ano ${ }^{-1}$, enquanto que Corsi et al. (2004) estima que na maioria das propriedades rurais brasileiras esse índice não ultrapassaria as $75 \mathrm{~kg}$ de carcaça.ha ${ }^{-1} \cdot$ ano $^{-1}$.

A situação de baixa produtividade tem desestimulado os produtores a se manterem na atividade pecuária, como aponta o trabalho de Faria et al. (1996). Esse autor constatou que entre 1969 e 1980 houve, somente no estado de São Paulo, uma redução de 1 milhão de ha de pastagens, os quais foram ocupados principalmente por cana-de-açúcar, soja e citros. Dados do Instituto de Economia Agrícola (2004b) retratam redução da área de pastagens em São 
Paulo, somente entre 2001 e 2003 de 181 mil ha, enquanto as áreas de canade-açúcar e soja aumentaram em 248 e 96 mil ha, respectivamente.

Trabalhos como o de Faria et al. (1996) mostram a incapacidade da pecuária extensiva competir com outras alternativas de uso da terra em termos de resultados econômicos, principalmente em regiões de terras valorizadas, como as do estado de São Paulo (IEA, 2004a). A conseqüência disso é o deslocamento da pecuária para as regiões periféricas ou de fronteira, ocupando áreas originalmente de floresta ou cerrado. No entanto, existe uma tendência das áreas de pastagens tomadas pela agricultura não serem repostas integralmente nas áreas de fronteira, como relataram Corsi et al. (2000).

Esses autores sugeriram que a perspectiva de abertura de novas áreas seria inferior a $20 \%$ nos próximos anos, além de afirmarem que a população brasileira e mundial deverá crescer em ritmo acelerado nas próximas duas décadas, além de ocorrerem mudanças nos seus padrões alimentares, como maior consumo de carne e leite. A afirmação de Corsi et al. (2000) está de acordo tanto com o aumento do rebanho bovino em cerca de 32 milhões de cabeças entre 1996 e 2003 (IBGE, 2004), quanto com a redução da abertura de novas áreas no chamado "arco do desmatamento" (região periférica da Amazônia legal que compreende os estados do Acre, Rondônia, Mato Grosso, Amazonas, Pará, Tocantins e Maranhão), de cerca de quase 280 mil ha, quando comprados os levantamentos via sensoriamento remoto dos anos de 1999/2000 e 2000/2001 (Instituto Brasileiro do Meio Ambiente e dos Recursos Naturais Renováveis, 2004)

A redução das áreas de pastagens no Centro-Sul do país em ritmo mais acelerado que o de abertura de novas áreas em regiões de fronteira, juntamente com o aumento consistente do rebanho bovino devem convergir para o aumento da produtividade animal nas áreas já existentes. Desse modo, ocorreriam acréscimos na rentabilidade da atividade pecuária, além de atender a demanda crescente da população por produtos de origem animal. 
Corsi et al. (2004) discutindo os diferentes componentes promotores da intensificação da produtividade animal, relataram que ganhos em taxa de lotação podem reverter em respostas até 4,5 vezes maiores que aumentos no desempenho individual dos animais, sendo essa a variável que deve ser explorada prioritariamente. Um dos principais limitantes do aumento das taxas de lotação é a baixa produção de forragem no período das "secas", resultado da estacionalidade de produção forrageira, caracterizada por representar acúmulos de 10 a $20 \%$ da produção anual de forragem nessa época do ano (Martha Júnior \& Corsi, 2001; Pedreira \& Mattos, 1981). Os produtores, por não disporem de alternativas voltadas ao controle da produção estacional de forragem, mantém as taxas de lotação da propriedade em níveis compatíveis com o período de escassez de recursos forrageiros.

Alternativas capazes de resolver, ou pelo menos minimizar a estacionalidade de produção, no sentido de promover incrementos de lotação sem a necessidade de elevados investimentos, são de extrema importância para a pecuária nacional. Nesse contexto, o diferimento de pastagens, que consiste em vedar determinadas áreas no final da estação chuvosa para subseqüente utilização durante o período seco, tem sido apresentado como solução técnica e economicamente viável para amenizar a defasagem de massa de forragem entre os períodos de "verão" e "inverno" (Costa \& Oliveira, 1992).

O uso de pastagens diferidas tem fácil aceitação entre os pecuaristas, uma vez que durante o verão ocorre excesso de produção de forragem e, desse modo, o diferimento não implicaria em maiores investimentos e nem comprometeria os níveis de produtividade animal observados na propriedade. A adoção dessa técnica, no entanto, deve ser vista de maneira integrada na propriedade, ou seja, o dimensionamento da área a ser diferida deve contemplar a necessidade de forragem para as "secas" e as "águas" .

Quando se planeja a dimensão da área a ser vedada, é necessário considerar que o restante da propriedade será submetido a uma intensidade de 
pastejo mais elevada durante o período de diferimento. Sem dúvida esse planejamento assume maior importância pelo fato de que o diferimento ocorre quando as condições climáticas não são as mais favoráveis ao crescimento rápido das plantas forrageiras.

Assim, o uso de fertilizantes em pastagens diferidas aceleraria o ritmo de crescimento da planta, compensando ocasionais atrasos no inicio do diferimento, promoveria incrementos na produção de forragem (quando a pastagem fosse vedada na época correta), e diminuiria a dimensão da área a ser diferida.

Por outro lado, adubações nitrogenadas, principalmente na forma de uréia, estão sujeitas a maiores perdas de $\mathrm{NH}_{3}$ por volatilização nessa época do ano, caracterizada por temperaturas elevadas, chuvas escassas e umidade residual no solo ainda elevada. Nesse sentido, estudos para se determinar a eficiência de diferentes fontes nitrogenadas além da associação da uréia com outros fertilizantes como cloretos e sulfatos, no sentido de controlar as perdas de $\mathrm{N}$ por volatilização, poderiam definir técnicas de manejo para melhorar o uso da adubação na área diferida.

$O$ presente trabalho teve por objetivo avaliar o efeito de diferentes fontes nitrogenadas e associações de fertilizantes no momento do diferimento de $B$. brizantha cv. Marandu sobre a produção de forragem e recuperação do nitrogênio aplicado ao longo dos períodos de crescimento da planta, pastejo e rebrota, além do valor nutritivo da forragem pastejada e das perdas por pastejo. 


\section{REVISÃO DE LITERATURA}

\subsection{Estacionalidade de Produção da Planta Forrageira}

Dentre os aspectos desejáveis à escolha e utilização de uma espécie forrageira, a boa distribuição da produção ao longo do ano pode ser considerada um dos atributos mais cobiçados, tanto por parte dos pesquisadores quanto por parte dos pecuaristas (Rolim, 1994; Jank, 1995), uma vez que a baixa produção de forragem no período das "secas" ou "inverno" é considerada como um dos principais fatores que contribuem para a baixa produtividade animal nesse ambiente (Corsi, 1976; Boin, 1985).

No entanto, a busca do equilíbrio na produção de forragem através do uso de novas espécies ou cultivares forrageiros não tem apresentado resultados satisfatórios, uma vez que a oscilação no ritmo de crescimento das plantas forrageiras, a chamada estacionalidade de produção forrageira, é, em grande parte, inerente a fatores climáticos como temperatura, luminosidade $\mathrm{e}$ disponibilidade hídrica (Martha Júnior \& Balsalobre, 2001), fatores estes que apresentam comportamento estacional bem definido no Brasil Central (Figuras 1, 2 e 3). Soto (1981) explica que no Brasil Central a radiação solar recebida de maio a agosto (época normalmente definida como "inverno" ou "secas") é cerca de $51 \%$ menor daquela do período de novembro a fevereiro ("verão" ou época das "águas"), além de ocorrerem concomitantemente reduções no fotoperíodo. 


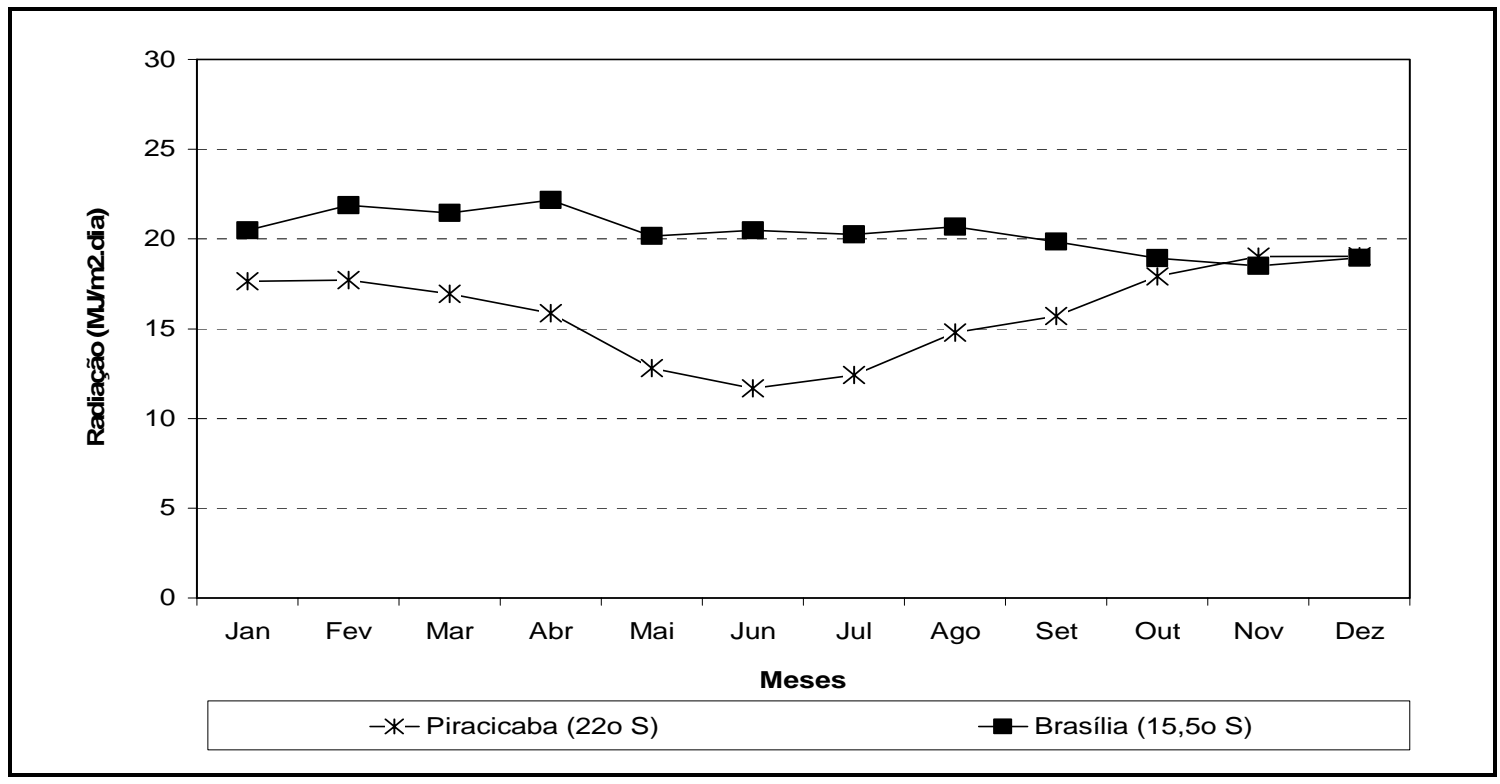

Figura 1 - Variação mensal da radiação solar ao longo do ano em PiracicabaSP (período de 1994 a 2003) e Brasília-DF (período de 1971 a 2002)

Fonte: EMBRAPA CNPH (2004); ESALQ/USP DCE (2004)

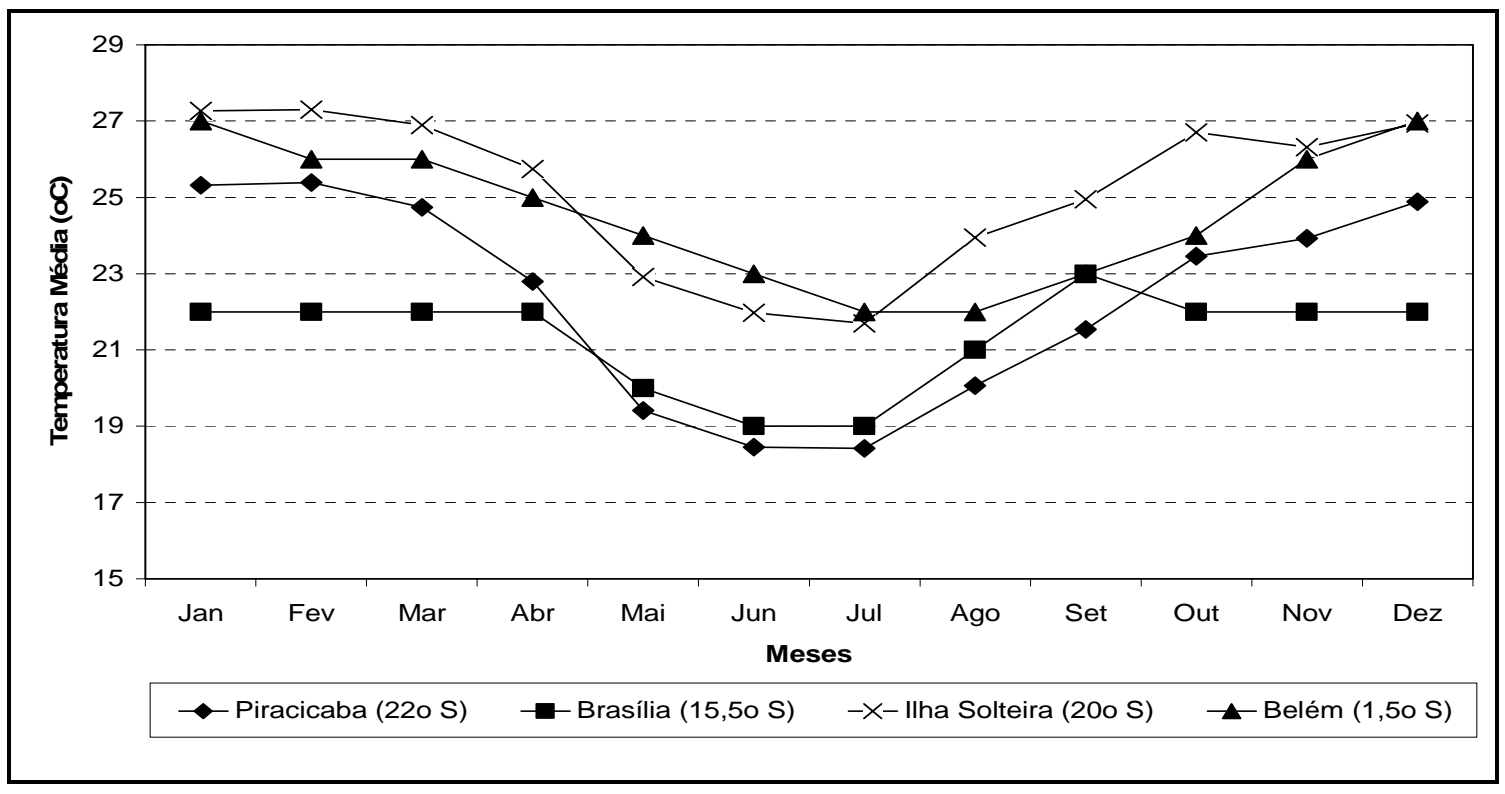

Figura 2 - Variação mensal da temperatura média ao longo do ano em diferentes localidades do Brasil

Fonte: ESALQ/USP DCE (2004); FEIS/UNESP (2004); Canal do Tempo (2004) 


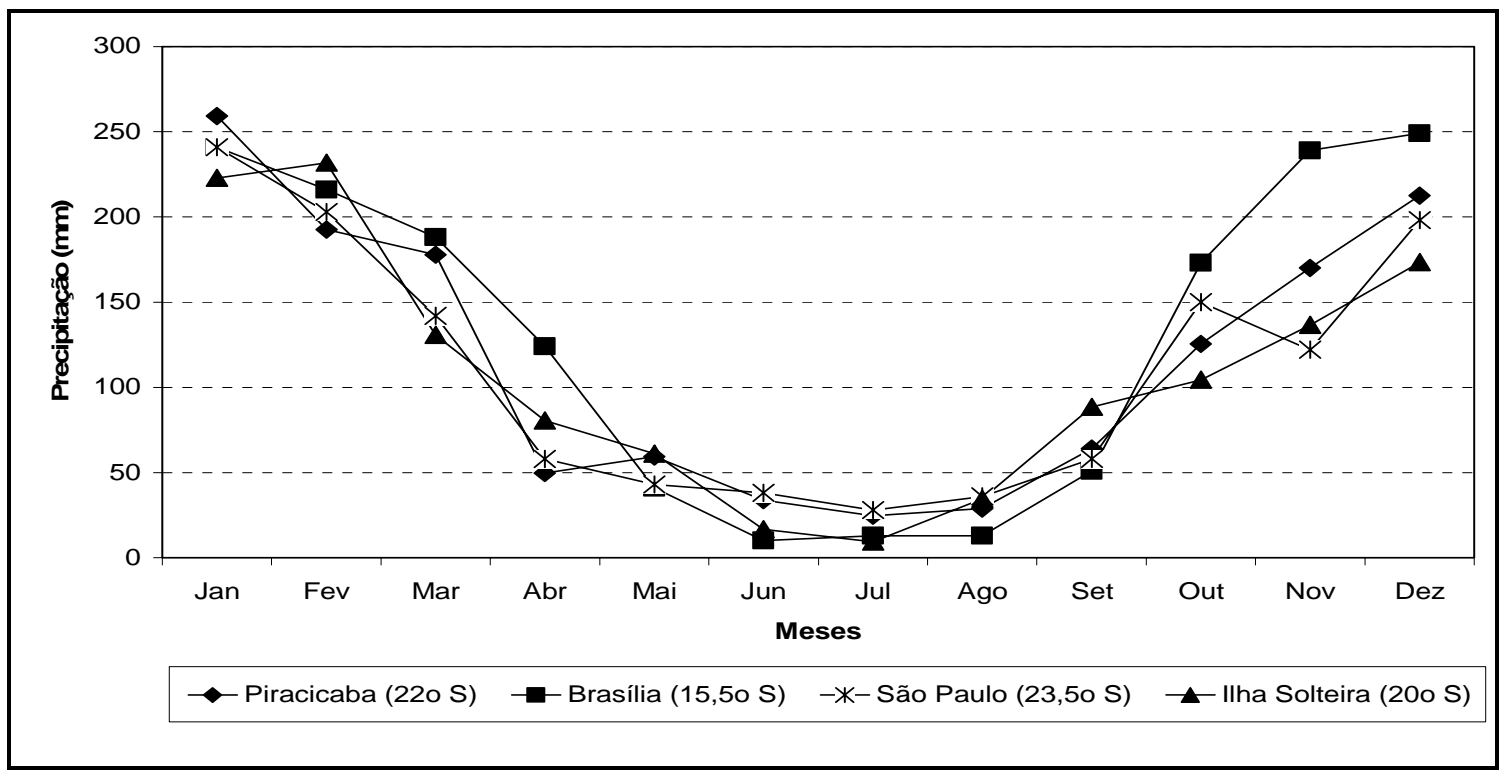

Figura 3 - Variação mensal da precipitação pluvial em diferentes localidades ao longo do ano

Fonte: ESALQ/USP DCE (2004); FEIS/UNESP (2004); Canal do Tempo (2004)

Nesse contexto, o conhecimento e quantificação dessa variação estacional de produção forrageira tem elevada influência sobre o planejamento, adequação de técnicas e tomadas de decisões na propriedade rural (Boin, 1985; Barioni, 2002).

\subsubsection{Influência dos fatores climáticos sobre a produção das pastagens}

As plantas forrageiras tropicais, devido ao metabolismo fotossintético $\mathrm{C}_{4}$, apresentam taxa de fotossíntese máxima entre $30-35^{\circ} \mathrm{C}$ e mínima ao redor de $15^{\circ} \mathrm{C}$, além de não apresentarem saturação fotossintética com aumentos na intensidade de luz (Corsi \& Nascimento Júnior, 1994).

Sendo assim, quanto mais favoráveis as condições de temperatura, fotoperíodo e intensidade de luz, mais acelerado será o ritmo de crescimento da 
planta. Essa afirmação pode ser ratificada através dos trabalhos de t'Mannetje \& Pritchard (1974) e t'Mannetje (1975), onde a associação de baixas temperaturas e curtos fotoperíodos foram os principais fatores climáticos limitantes ao crescimento de espécies forrageiras tropicais e subtropicais.

Estes autores tentaram separar os efeitos de temperatura e de fotoperíodo, porém os resultados decorrentes desses fatores dificilmente podem ser completamente isolados. Para uma determinada condição de temperaturas diurnas e noturnas, variações no fotoperíodo inevitavelmente alterariam a temperatura média de 24 horas, uma vez que ocorreriam alterações na participação relativa dessas temperaturas no cálculo do valor médio diário.

Sendo a temperatura e luminosidade os principais fatores limitantes ao crescimento da planta, nas regiões próximas ao Equador, onde se verificam variações menores na temperatura e luminosidade ao longo do ano (Figuras 1 e 2), a estacionalidade de produção deveria ser um fenômeno menos pronunciado. Nessa situação, deve-se atentar para o regime hídrico da região, uma vez que a precipitação pluvial certamente passará a ser o maior determinante do crescimento da planta em certas épocas do ano (Figura 3), visto que gramíneas tropicais necessitam de, pelo menos, $250 \mathrm{~kg}$ de água para produzir $1 \mathrm{~kg}$ de MS (Martha Júnior \& Balsalobre, 2001).

\subsubsection{Quantificação da estacionalidade de produção das pastagens ao longo do ano}

Vários trabalhos foram desenvolvidos no intuito de se quantificar o efeito da estacionalidade de produção em diferentes espécies forrageiras (Tabela 1).

A porcentagem de produção de forragem na seca foi apresentada de duas maneiras: a primeira como fração da produção total anual, cujo objetivo é denotar qual a ordem de grandeza do crescimento estacional da planta; e a segunda como fração da produção das "águas", cujo objetivo é verificar qual a 
capacidade de suporte da área nas "secas" em relação à obtida durante a estação de crescimento. Em outras palavras, apesar da produção de inverno participar com apenas $21,60 \%$ da produção total na média dos trabalhos citados, sua capacidade de suporte situa-se ao redor de 27,55\% da de "verão", resultando em uma variação de quase $30 \%$ somente na mudança da metodologia de cálculo.

Tabela 1. Produção anual e variação estacional de acúmulo de forragem para diferentes espécies forrageiras

\begin{tabular}{|c|c|c|c|c|c|}
\hline \multirow{2}{*}{$\begin{array}{l}\text { Espécie } \\
\text { Forrageira }\end{array}$} & \multicolumn{4}{|c|}{-------------Produção de MS------------- } & \multirow[b]{2}{*}{ Fonte } \\
\hline & $\begin{array}{l}\text { Anual } \\
\left(\text { t.ha }^{-1}\right)\end{array}$ & $\begin{array}{c}\text { "Águas" } \\
(\%)^{1}\end{array}$ & $\begin{array}{l}\text { "Secas" } \\
(\%)^{1}\end{array}$ & $\begin{array}{c}\text { "Secas" } \\
(\%)^{2}\end{array}$ & \\
\hline Capim-elefante $^{3}$ & 23,1 & 75,75 & 24,25 & 32,01 & Ghelfi Filho, 1972 \\
\hline $\begin{array}{c}25 \text { gramíneas } \\
\text { forrageiras }^{4}\end{array}$ & 10,6 & 86,43 & 13,57 & 15,69 & $\begin{array}{c}\text { Pedreira \& Mattos, } \\
1981\end{array}$ \\
\hline $\begin{array}{l}8 \text { cultivares de } \\
\text { Capim-elefante }{ }^{4}\end{array}$ & 13,1 & 72,11 & 27,89 & 38,67 & $\begin{array}{c}\text { Pedreira \& Mattos, } \\
1982\end{array}$ \\
\hline $\begin{array}{l}8 \text { Leguminosas } \\
\text { forrageiras }^{4}\end{array}$ & 4,3 & 80,68 & 19,32 & 23,95 & $\begin{array}{c}\text { Mattos \& Pedreira, } \\
1984\end{array}$ \\
\hline Capim-Tanzânia & 29,5 & 80 & 20 & 25 & Tosi, 1999 \\
\hline $\begin{array}{l}5 \text { cultivares de } \\
\text { Cynodon spp. }{ }^{3}\end{array}$ & 26,0 & 72,7 & 27,3 & 37,56 & Tonato, 2003 \\
\hline Capim-Marandu & 26,3 & 81,11 & 18,89 & 23,29 & Andrade, 2004 \\
\hline Média & & 78,40 & 21,60 & 27,55 & - \\
\hline
\end{tabular}

${ }^{1}$ Porcentagem, por período, da produção anual de forragem

${ }^{2}$ Valor percentual em relação produção do período das águas

${ }^{3}$ Uso de Irrigação

${ }^{4}$ Valores médios

Por outro lado, independente de como os valores são calculados, as diferenças entre verão e inverno são marcantes, fazendo com que o 
desenvolvimento e adoção de técnicas para anular, ou pelo menos amenizar, os efeitos da estacionalidade de produção se façam necessários.

\subsection{3 Índices climáticos utilizados para previsão de produtividade}

Estudos envolvendo a produção estacional de várias espécies forrageiras podem ser encontrados na literatura (Tabela 1). Entretanto, a comparação dos resultados entre experimentos é difícil, devido a variações regionais e temporais (características climáticas pontuais dos anos de coleta dos dados) específicas de cada trabalho.

Alguns estudos foram desenvolvidos objetivando isolar os efeitos de variáveis climáticas, ou padronizando-as para possibilitar a comparação de resultados entre experimentos.

Ghelfi Filho (1972) e Tonato (2003) desenvolveram experimentos com forragens irrigadas procurando isolar o efeito do déficit hídrico sobre o acúmulo de forragem. Os resultados obtidos por esses autores refletiram em maiores produções no período das "secas", quando comparados à média dos valores observados na Tabela 1. Por outro lado, o contraste de produção entre verão e inverno ainda foi acentuado, demonstrando a influência dos demais fatores climáticos no sistema.

Além da influência do status hídrico do solo na produção forrageira, os efeitos de temperatura e fotoperíodo foram determinados através de modelos matemáticos ou índices climáticos, sendo que um dos primeiros conceitos foi o de grau-dia (GD), proposto por Villa Nova (1972), e definido como a energia ou soma calórica diária disponível para a planta.

O GD é baseado na diferença entre a temperatura média diária e a temperatura na qual a planta cessaria seu crescimento, denominada de temperatura base inferior (TBi), multiplicada pelo número de dias. 
Nabinger \& Pontes (2001) relataram que na ausência de condições limitantes ao crescimento (como água, nutrientes, temperatura e luminosidade), a atividade meristemática da planta forrageira, e conseqüentemente o acúmulo de biomassa são regulados pelo tempo térmico decorrido, medido através do acúmulo de graus-dia. Essa afirmação foi comprovada por Almeida et al. (1997), determinando que a taxa de aparecimento de folhas e duração de vida da folha para o capim elefante anão manejado sob diferentes ofertas de forragem foram respectivamente de 85 e $782 \mathrm{GD}$, não verificando efeito da desfolhação sobre essas variáveis.

Villa Nova et al. (1999), no entanto, verificaram que em alguns trabalhos relativos a estacionalidade de produção forrageira, os picos de produção não coincidiam com as épocas de maior temperatura, indicando que modelos baseados apenas na soma térmica poderiam ser inadequados ou incompletos. Esses autores, sugeriram que outros fatores, como o fotoperíodo, deveriam estar influenciando o crescimento das plantas forrageiras e propuseram o uso de unidade fototérmica (UF), para explicar as variações estacionais de crescimento, uma vez que essa variável considera a interação da temperatura do ar com o fotoperíodo (Villa Nova et al., 1983).

A partir dos estudos envolvendo GD e UF foram definidos modelos de simulações para estimar a produção de forragem em diferentes locais que dispusessem de informações sobre temperatura e fotoperíodo.

Nos trabalhos de Tonato (2003) e Villa Nova et al. (1999), os conceitos de GD e UF foram testados em Cynodon spp. e Capim-elefante, obtendo-se regressões com coeficientes de determinação de 0,69 (GD), e 0,71 e 0,97 (UF), capazes de estimar a produção dessas plantas forrageiras desde que na ausência de déficit hídrico. 


\subsection{Alternativas para minimizar a produção estacional de forragem}

Várias são as técnicas ou alternativas empregadas no sentido de se solucionar o problema da estacionalidade de produção, sendo que a escolha correta de ações deve ser condizente com o nível de exploração pecuária da propriedade (Rolim, 1994).

Nesse sentido, Rolim (1994) listou várias técnicas de intensificação do sistema de produção, sendo elas: adoção do pastejo diferido, uso de espécies forrageiras com produção anual mais homogênea, conservação de forragens suplementares e irrigação. Esse autor também ressaltou que essas alternativas foram apresentadas de forma crescente quanto ao nível tecnológico a ser empregado, além de se buscar a adoção simultânea de várias delas no sentido de melhor explorar o potencial produtivo das plantas forrageiras.

A irrigação de pastagens apresenta resultados positivos e melhor distribuição de produção quando a temperatura e luminosidade não são limitantes ao crescimento da planta, como discutido por Ghelfi Filho (1972) e Tonato (2003), onde mesmo na ausência de deficiência hídrica a estacionalidade de produção foi bastante acentuada (Tabela 1).

Em regiões mais próximas ao Equador, onde variações de luminosidade e temperatura são menores, possivelmente a irrigação seria uma alternativa tecnicamente viável. No entanto, fatores mercadológicos como valor de aquisição de insumos e venda de animais podem inviabilizar economicamente o sistema (Balsalobre et al., 2003).

Em relação ao uso de espécies forrageiras com melhor distribuição estacional de produção, alguns trabalhos têm mostrado que espécies com menor estacionalidade de produção normalmente também são menos produtivas (Jank, 1995), verificando-se assim uma correlação negativa entre potencial produtivo e estacionalidade, o que dificulta a seleção de plantas 
altamente produtivas com pequena variação estacional de produção (Jank et al., 1994).

No caso da adoção do uso de capineiras ou de outros volumosos suplementares, deve-se considerar a capacidade de assimilação de tal estratégia pelo sistema, uma vez que esta envolve atividades mais tecnificadas, mecanizadas e, conseqüentemente, mais onerosas, justificando-se, provavelmente, somente em escalas maiores de produção. Por outro lado, talvez essa seja a única técnica que possibilitaria explorar a elevada produtividade das pastagens durante a estação de crescimento.

\subsection{Diferimento de pastagens}

O diferimento de pastagens, que consiste em vedar determinadas áreas de pasto no final da estação chuvosa para subseqüente utilização durante o período seco, tem sido apresentado como solução técnica e economicamente viável para amenizar a defasagem de produção de forragem entre os períodos de "verão" e "inverno" (Costa \& Oliveira, 1992).

O uso de pastagens diferidas tem fácil aceitação entre os pecuaristas uma vez que durante o "verão" ocorre excesso de produção de forragem, resultado da taxa de lotação da propriedade ser dimensionada a partir da produtividade das "secas", e desse modo, o diferimento não implicaria em maiores investimentos e nem comprometeria os níveis de produtividade animal obtidos normalmente (Martha Júnior \& Balsalobre, 2001). Por outro lado, segundo Martha Júnior \& Balsalobre (2001), empreendimentos baseados na exploração de pastos diferidos são caracterizados por taxas de lotação animal raramente superiores a 1,5 e 2,0 UA.ha ${ }^{-1}$. ano ${ }^{-1}$, o que limita seu uso a sistemas em fase inicial de intensificação.

Para que haja sucesso na adoção do diferimento de pastagens deve contemplar fatores como a escolha da espécie forrageira, massa e oferta de 
forragem no momento de utilização da pastagem e as perdas decorrentes da utilização em pastejo.

A oferta de forragem é um dos principais fatores que determina 0 consumo, explicando até $73 \%$ da ingestão voluntária pelo animal, quando essa é determinada pela quantidade de folhas verdes (Euclides et al., 1999). Sem dúvida, o grau de seletividade de pastejo proporcionado pelo nível de oferta de forragem provoca diferentes desempenhos no animal tornando indispensável a avaliação da quantidade de forragem ofertada e da qualidade da forragem selecionada pelo mesmo. Incrementos na massa de forragem e, conseqüentemente, na oferta de forragem ou nas taxas de lotação, podem ser obtidos através de estratégias como a determinação das épocas de vedação e utilização da pastagem, bem como a adoção da adubação das pastagens a serem diferidas.

O uso de adubação, juntamente com a correta adoção da espécie forrageira a ser utilizada, também pode promover incrementos qualitativos ao sistema, principalmente em relação à PB, fração químico-bromatológica mais limitante no momento da utilização da pastagem diferida.

\subsubsection{Escolha da espécie forrageira}

O decréscimo no valor nutritivo da planta forrageira submetida a longos períodos de crescimento é um fenômeno inevitável, principalmente durante a época "seca", uma vez que as proporções de hastes e material morto geralmente aumentam, a relação folha:haste diminui e ocorre maior deposição de componentes estruturais na célula em detrimento aos componentes solúveis (Leite \& Euclides, 1994; Martha Júnior \& Corsi, 2001).

Desse modo, deve-se dar preferência à escolha de espécies forrageiras que se destacam pela capacidade de manutenção de características estruturais e nutricionais após considerável período de crescimento livre (i.e. acima de 90 
dias), em especial durante o final da estação de crescimento, as quais teriam condições de proporcionar a manutenção ou pequenos ganhos no peso do animal em pastejo. Leite \& Euclides (1994) e Martha Júnior \& Corsi (2001) recomendaram as espécies do gênero Cynodon e Brachiaria como as mais indicadas e utilizadas para o diferimento, principalmente a $B$. decumbens e a $B$. brizantha, o que pode ser ratificado através dos trabalhos de EUCLIDES et al. (1990), Costa et al. (1993), Pizarro et al. (1996) e Gomes (2003). Zimmer et al. (1994) apresentaram que $67 \%$ da área de pastagens brasileiras são ocupadas por essas duas espécies de Brachiaria, enquanto que em regiões como Campo Grande (MS) esses valores atingem 90\% (Costa, 2000).

A B. decumbens, entretanto, é uma das espécies forrageiras mais atacadas pela cigarrinha das pastagens - Deois flavopicta, Deois schach e Zulia entreriana (Silveira Neto, 1994) - aumentando o risco do planejamento do diferimento de áreas para o período seco, uma vez que os sintomas do ataque desses insetos são expressos mais intensamente no período de início do diferimento.

Assim, o diferimento de B. brizantha poderia ser considerado como alternativa para minimizar a estacionalidade na produção e no valor nutricional da planta forrageira durante o período seco do ano, sendo também o mais seguro, uma vez que essa espécie está menos sujeita ao ataque de pragas e doenças.

\subsection{2 Épocas de diferimento e utilização da pastagem}

O estudo de épocas de vedação e utilização da pastagem diferida é, sem dúvida, o tema mais estudado em trabalhos de pesquisa que abordam o diferimento de pastagens, sendo as combinações entre épocas de diferimento e utilização as mais variadas. De maneira geral, as épocas de diferimento estudadas variam de Janeiro a Abril, podendo em alguns trabalhos ser incluso o 
mês de Dezembro, enquanto que as épocas de utilização normalmente obedecem a amplitude de Maio a Setembro, podendo em alguns trabalhos ser incluso o mês de Outubro.

Pastagens diferidas precocemente, isto é, entre dezembro e início de fevereiro, acumulam maior quantidade de forragem para os períodos considerados críticos do ano (maio a setembro) (Costa \& Oliveira, 1992; Pizarro et al., 1993; Pizarro et al., 1996; Filgueiras et al., 1997; Bueno et al., 2000). Martha Júnior \& Balsalobre (2001) relacionaram o momento de início do diferimento aos fatores climáticos limitantes (temperatura e precipitação). Esses autores indicam que temperaturas mínimas inferiores a $15^{\circ} \mathrm{C}$ e precipitações mensais inferiores a $150 \mathrm{~mm}$ seriam limitantes ao crescimento de plantas forrageiras tropicais.

Por outro lado, pastagens cujo diferimento é demasiadamente prematuro podem apresentar problemas relacionados ao aumento da proporção de material senescido (Euclides et. al, 1990; Pizarro et al., 1996), além da maior propensão ao acamamento (Filgueiras et al., 1997) e às perdas por pastejo, principalmente caso sejam utilizadas na segunda metade do período seco. Além desses aspectos, decréscimos na digestibilidade in vitro da matéria seca (DIVMS) e nos teores de proteína bruta (PB) da forragem se mostraram mais acentuados para os tratamentos cujo diferimento foi realizado até o final de janeiro (Costa \& Oliveira, 1992; Pizarro et al., 1996; Leite et al., 1998; Filgueiras et al., 1997; Bueno et al., 2000), apresentando os menores valores ao final do período de utilização (agosto/setembro).

Os maiores valores de DIVMS e PB da forragem coincidiram com os diferimentos iniciados no final da estação de crescimento (março/abril), principalmente quando as avaliações ocorreram logo no início do período de utilização (maio/junho). Nas avaliações posteriores (julho a setembro), houve redução nos teores dessas frações da planta, porém eles sempre foram superiores aos observados nas pastagens submetidas às demais épocas de vedação. Por outro lado, pastagens diferidas no final da estação de crescimento 
e utilizadas no início do período crítico de produção de forragem apresentaram acúmulo de massa muito baixo, resultante do curto período de descanso e das condições climáticas desfavoráveis.

Sendo assim, Euclides et al. (1990), Costa \& Oliveira (1992), Leite et al. (1998) e Filgueiras et al. (1997) sugeriram que pastagens vedadas em março devem ser utilizadas na segunda metade da estação seca (final de julho a setembro). Os primeiros autores determinaram que plantas vedadas nessa época apresentaram forragem de valor nutritivo superior àquelas com maior período de crescimento, além de acumularem mais massa entre os meses de abril a início de julho em relação às demais estratégias de vedação, necessitando apenas de um período mais longo para que esses acúmulos fossem satisfatórios.

Costa et al. (1993) e Euclides \& Queiroz (2000) sugeriram estratégia de diferimento com o objetivo de atingir acúmulo de forragem associado à qualidade e eficiência na utilização. Essa estratégia foi definida como "vedação escalonada", onde determinadas áreas (ao redor de $40 \%$ do total a ser diferido) seriam vedadas em fevereiro para posterior utilização na primeira metade das "secas" (maio a meados de julho), enquanto que os $60 \%$ restantes seriam vedados de março a meados de julho, com utilização prevista até setembro.

Os autores explicam a ponderação nas áreas a serem diferidas baseados no maior potencial de crescimento das pastagens vedadas em fevereiro em relação a março, resultando em uma menor área necessária para satisfazer as necessidades de forragem na primeira metade da estação seca.

Apesar do relativo sucesso do diferimento quando adotada essa técnica, Martha Júnior \& Balsalobre (2001) enfatizam que essas recomendações servem como guia para tomadas de decisão, sendo necessários ajustes dependentes de condições inerentes de cada região ou propriedade, como foi relatado por Gomes (2003), que necessitou de vedas mais precoces (Janeiro) na região árida de Minas Gerais para obter acúmulos satisfatórios de forragem. 


\subsubsection{Acúmulo de forragem em áreas diferidas}

O acúmulo de forragem é definido pelo balanço entre crescimento da planta forrageira e desaparecimento desse material através do consumo animal, e/ou dos processos de senescência e decomposição.

Apesar da busca de um equilíbrio entre produção e valor nutritivo da forragem, dois importantes determinantes da produtividade animal, no caso de diferimento de pastagens, as estratégias adotadas devem ser voltadas para os aspectos quantitativos, uma vez que este é o fator de produção mais limitante durante o período seco do ano (Martha Júnior \& Balsalobre, 2001). Euclides \& Queiroz (2000) recomendaram oferta de forragem diferida ao redor de $4,5 \mathrm{~kg}$ MS.100 kg PV-1.dia ${ }^{-1}$ e, nesse sentido, quanto maior a massa de forragem, maior a taxa de lotação passível de ser atingida.

Durante o período de diferimento, o acúmulo de forragem é afetado negativamente pelas taxas de senescência e decomposição, uma vez que os animais ainda não têm acesso às áreas diferidas. O aumento da interceptação luminosa pelo dossel é o maior determinante na variação dessas taxas (Korte et al., 1982).

Quando 95\% da luz incidente é interceptada com o mínimo possível de auto-sombreamento, obtém-se a máxima taxa de crescimento do dossel, o que acontece no ponto chamado de índice de área foliar ótimo (IAFótimo). Abaixo deste ponto a produtividade da pastagem é dependente do IAF e acima do mesmo, o sombreamento excessivo provocaria aumento das perdas respiratórias e conseqüentemente decréscimo no acúmulo líquido de forragem (Silva, S., 2002). Em outras palavras, o crescimento da planta pode ser dividido em três fases: a fase anterior ao $\mathrm{IAF}_{\text {ótimo, }}$ onde a taxa de acúmulo de forragem é potencializada; a fase posterior ao $\mathrm{IAF}_{\text {ótimo, }}$ onde a forragem seria subutilizada,

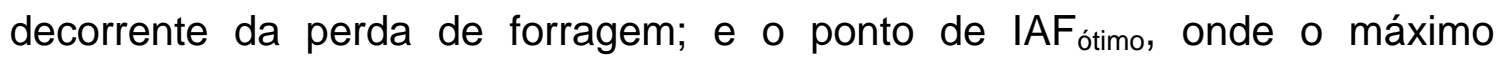
acúmulo de forragem foi atingido em associação com o mínimo de perdas. 
O efeito da competição por luz sobre as mudanças no dossel foi apresentado por Carnevalli (2003) estudando o capim Mombaça em lotação rotacionada. Quando o dossel interceptou mais que 95\% da luz incidente, ocorreu aumento significativo na produção de hastes e material morto, enquanto que o acumulo de folhas se manteve (Figura 4).

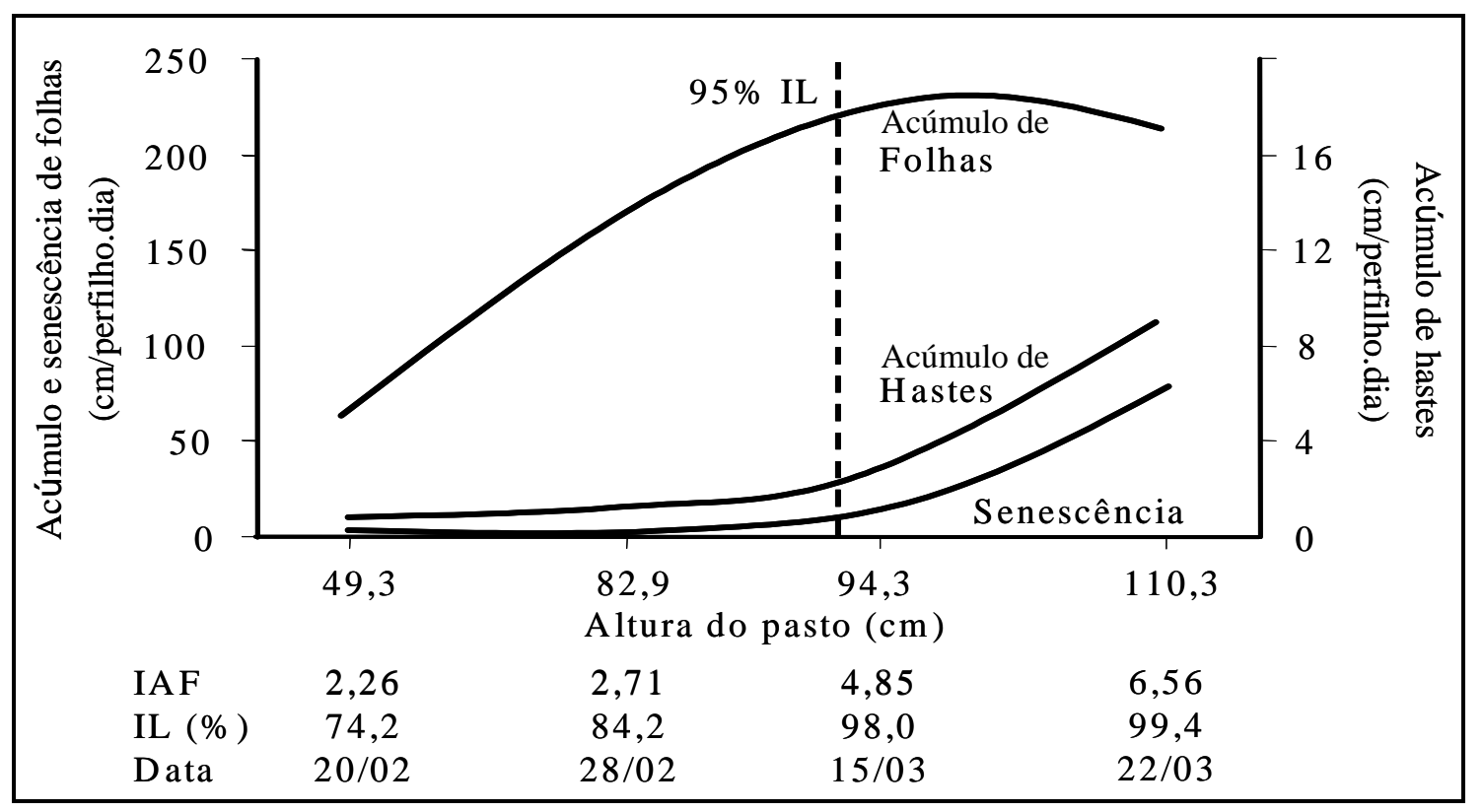

Figura 4 - Acúmulo de hastes e folhas e senescência de folhas em função da interceptação luminosa pelo dossel forrageiro de capim mombaça em lotação rotacionada

Fonte: Carnevalli (2003)

Os trabalhos na literatura (Tabela 2), relatam grande amplitude de resultados, normalmente conseqüência das diferentes combinações entre épocas de vedação e utilização. Todos os trabalhos compilados na Tabela 2 foram avaliados através de cortes, ou seja, foi considerado apenas o momento em que os animais entrariam nas áreas diferidas, enquanto que outros fatores, como as perdas por pastejo, não foram considerados na escolha do momento da entrada dos animais. Diferenças na eficiência de pastejo poderiam fazer com 
que produções distintas de forragem fossem revertidas em produtividades animais semelhantes (Teixeira, 1998).

Tabela 2. Massa de forragem máxima e mínima em pastagens diferidas, no momento da utilização

\begin{tabular}{|c|c|c|c|c|c|}
\hline \multirow{2}{*}{ Espécie } & \multirow{2}{*}{$\begin{array}{c}\text { Valor } \\
\text { Mínimo }\end{array}$} & \multirow{2}{*}{$\begin{array}{c}\text { Valor } \\
\text { Máximo }\end{array}$} & \multicolumn{2}{|c|}{ Crescimento $^{2}$} & \multirow{2}{*}{ Fonte } \\
\hline & & & Mínimo & Máximo & \\
\hline & \multicolumn{2}{|c|}{--------MS--------- } & \multicolumn{2}{|c|}{---------dias--------- } & \\
\hline B. decumbens & 1395 & 6951 & 33 & 173 & $\begin{array}{l}\text { Paulino et al. } \\
\qquad(1995)^{1}\end{array}$ \\
\hline B. decumbens & 4000 & 9400 & 28 & 308 & Pizarro et al. (1996) \\
\hline B. brizantha ${ }^{3}$ & 1700 & 7680 & 60 & 210 & Leite et al. (1998) \\
\hline \multirow[t]{2}{*}{ B. brizantha } & 3958 & 10263 & 48 & 224 & Gomes (2003) \\
\hline & \multicolumn{2}{|c|}{---------MSV---------- } & & & \\
\hline $\begin{array}{l}\text { Brachiaria e } \\
\text { Cynodon }^{4}\end{array}$ & 1458 & 7450 & 30 & 240 & $\begin{array}{l}\text { Euclides et al. } \\
\qquad(1990)\end{array}$ \\
\hline $\begin{array}{l}\text { A. gayanus cv. } \\
\text { Planaltina }\end{array}$ & 1370 & 7081 & 61 & 214 & $\begin{array}{c}\text { Costa \& Oliveira } \\
\text { (1992) }\end{array}$ \\
\hline Capim-marandu & 2744 & 9123 & 63 & 214 & Costa et al. (1993) \\
\hline Capim-marandu & 2405 & 5740 & 48 & 224 & Gomes (2003) \\
\hline
\end{tabular}

${ }^{1}$ Foram testadas fontes de nitrogênio, e não épocas de vedação e utilização

2 Período em que a pastagem permaneceu vedada para posterior utilização no período das secas

${ }^{3}$ B. brizantha cv. Marandu, cv. BRA-002801 e cv. BRA-004391

${ }^{4}$ B. humidicola, B. decumbens e C. plectostachuys

Nos trabalhos de Euclides et al. (1990), Costa et al. (1993), Pizarro et al. (1996) e Paulino et al. (1995), os tratamentos que propiciaram melhores condições de crescimento da planta (pastagem vedada em janeiro, fevereiro, dezembro, e uso de sulfato de amônio, respectivamente) tiveram seu pico de produção ocorrendo entre os meses de maio e julho. Assim, apesar das pastagens submetidas e esses tratamentos terem acumulado mais forragem até 
a metade do período seco, em agosto e setembro suas produções foram semelhantes ou inferiores às estratégias mais tardias de vedação, sugerindo que o dossel forrageiro já se encontrava na fase posterior ao IAF $_{\text {ótimo. Nessa }}$ situação, seria recomendada a utilização mais precoce da pastagem.

A utilização da pastagem após um período mais curto de vedação evitaria a competição por luz no dossel, caracterizada pelo alongamento das hastes, retardamento do aparecimento de folhas e aceleração da morte de tecidos, que podem desaparecer do sistema devido ao desenvolvimento de fungos saprófitos (Preston \& Leng, 1987, citado por Reis et al., 1996 e Gomes, 2003). No entanto, se a situação de competição por luz persistir, certamente o aparecimento de tecidos novos ocorrerá em um ritmo mais lento que o de desaparecimento de material senescido, resultando em decréscimos no acúmulo líquido de forragem.

No trabalho de Euclides et al. (1990) foram observadas taxas de acúmulo líquido de forragem negativas comparando-se a $B$. humidicola diferida no mês de janeiro e utilizada nos meses de maio e setembro, quando as produções foram respectivamente de 7500 e $3800 \mathrm{~kg} \mathrm{MS}$.ha $^{-1}$. Por outro lado, as pastagens vedadas em março apresentaram taxas instantâneas de acúmulo líquido de forragem crescentes entre os meses de utilização, produzindo $1500 \mathrm{e}$ $3500 \mathrm{~kg} \mathrm{MS}$.ha ${ }^{-1}$ para a $B$. decumbens em maio e setembro, respectivamente. As parcelas vedadas em fevereiro, por sua vez, mantiveram suas produções estáveis ao redor de $3000 \mathrm{~kg} \mathrm{MS}$. ha ${ }^{-1}$ para a $B$. humidicola ao longo dos meses de utilização.

Os resultados apresentados por Euclides et al. (1990) reforçam o uso da vedação escalonada, onde a vedação da pastagem seria condicionada ao momento de entrada dos animais, de modo que nesse momento o dossel forrageiro estivesse em uma situação próxima ou coincidente com o seu IAFótimo.

O trabalho de Euclides et al. (1990) foi um dos compilados na Tabela 2 onde os resultados foram expressos em acúmulo de MSV, o que auxiliou na 
visualização das diferentes fases de crescimento da planta, uma vez que o material morto ainda aderido à planta foi descartado, resultando em curvas melhor definidas. O uso da MSV também é importante quando se avalia consumo e desempenho animal, já que gramíneas forrageiras tropicais acumulam grande quantidade de material senescido nas "secas" e, dessa forma, alguns autores (Euclides et al., 1990; Euclides et al., 1999; Gomes, 2003) afirmaram que as melhores correlações entre consumo ou desempenho são obtidas com MSV do que com a MS total.

Por outro lado, o uso da pastagem por tempos prolongados, ao invés da avaliação pontual efetuada através de cortes, associados à intensidade de pastejo, promoveriam mudanças na massa e qualidade do material forrageiro, e na estrutura do dossel, principalmente decorrente da menor participação do material verde, em especial folhas e hastes novas, que são preferencialmente ingeridas no início do período de pastejo.

Chacon \& Stobbs (1976) estudando Setaria anceps cv. Kazungula pastejada por 15 dias, determinaram que a participação de folhas verdes na forragem ofertada foi de $35 \%$ e $7,5 \%$ para o primeiro e $15^{\circ}$ dia de pastejo, respectivamente. Esse resultado indica que no final do período de utilização os animais convivem com uma situação de baixa ou nenhuma oferta de material verde. Além disso, os mesmos autores determinaram que as folhas compuseram aproximadamente $100 \%$ e $56 \%$ da dieta nos mesmos períodos, indicando que, dependendo da oferta de forragem, o animal exerce pastejo seletivo, melhorando a composição do material ingerido. Euclides et al. (1992) relataram que em pastagens de $B$. decumbens no "período das águas", a MSV representou $26 \%$ da forragem em oferta, mas participava com $90 \%$ da dieta do animal. No período das secas, a participação era de $30 \%$, sendo esta selecionada de um dossel contendo $2,5 \%$ da massa.

Conclui-se que a MSV, apesar de gerar dados importantes de consumo e desempenho animal, não deve ser avaliada isoladamente em pastagens diferidas, e sim associada à MS total, para se estimar a capacidade de suporte 
da pastagem. A intensidade e período de pastejo, capacidade de seleção do animal, além dos fatores climáticos, em especial a precipitação, podem alterar substancialmente as condições de valor nutritivo da forragem.

\subsubsection{Valor nutritivo da forragem em pastagens diferidas}

Qualidade da forragem é definida como a associação entre valor nutritivo e consumo da mesma pelo animal em pastejo. O valor nutritivo, por sua vez, é dado pela composição química e digestibilidade (Reis \& Rodrigues, 1993). Desse modo, a qualidade da forragem é influenciada tanto por fatores nutricionais (valor nutritivo), quanto pelos não nutricionais (quantidade de forragem ofertada ao animal) (Poppi et al., 1987).

Plantas forrageiras, principalmente as de ciclo fotossintético $\mathrm{C}_{4}$, quando crescem em condições de temperaturas mais amenas e de déficit hídrico moderado apresentam valor nutritivo superior, uma vez que altas temperaturas acarretam aumentos na espessura da parede celular em detrimento aos componentes solúveis (Van Soest, 1994). Além disso, deficiências hídricas suaves, ao mesmo tempo que reduzem o crescimento da planta, retardando o aparecimento de hastes (Reis \& Rodrigues, 1993), promovem efeito de concentração dos nutrientes absorvidos (Balsalobre, 2002).

As condições climáticas no decorrer do período seco, e coincidentemente com o período de diferimento da pastagem, são de temperaturas em declínio e déficit hídrico crescente, fatores que concorrem para reduzir a velocidade de decréscimo do valor nutritivo da forragem, dependendo da época do ano e extensão do período de diferimento.

Por outro lado, períodos longos de crescimento, apesar de resultarem em maiores acúmulos de forragem, contribuem para um menor valor nutritivo, tanto por modificações na estrutura do dossel, através do aumento nas frações haste e material senescido e decréscimo proporcional na produção de folhas (Reis \& 
Rodrigues, 1993; Carnevalli, 2003), quanto por alterações em nível celular, representado pelo aumento dos teores de carboidratos estruturais e lignina (componentes da parede celular) e reduções no conteúdo celular (Reis \& Rodrigues, 1993; Van Soest, 1994). Assim, durante o diferimento de pastagens, deve ocorrer queda no valor nutritivo da forragem, uma vez que os possíveis fatores de melhora da mesma são anulados pelos longos períodos de vedação e pela deficiência hídrica severa, inerentes à época do ano. Nesse contexto, o diferimento de pastagens deve atender a demanda do rebanho com quantidade de forragem e valor nutritivo adequados a ganhos de peso reduzidos ou que proporcionem condições para explorar o ganho compensatório como sugerem Euclides et al. (2001) e Euclides et al. (1998), respectivamente.

Foi sumarizado na Tabela 3 trabalhos avaliando a composição químicobromatológica e digestibilidade da forragem de pastagens diferidas no momento de sua utilização. Os trabalhos apresentados foram avaliados em cortes, sendo que os tratamentos testaram diferentes épocas de vedação e utilização da pastagem. Dessa forma os valores mínimo e máximo representam o intervalo gerado pelos diferentes períodos de crescimento da planta forrageira em cada experimento.

Leite et al. (1998), Pizarro et al. (1996), Bueno et al. (2000) e Gomes (2003) determinaram que a época de utilização da forragem foi a que mais influenciou nos teores de PB, com valores entre $2,5 \%$ e $4,0 \%$ nas avaliações realizadas em setembro. Nos demais trabalhos, independente dos efeitos de momento de vedação ou interação entre momentos de vedação e utilização, constatou-se menores teores de PB nos períodos de crescimento mais prolongados.

Reis (2000), estudando o valor nutritivo de gramíneas tropicais em diferentes idades de corte, mostrou que a variação no teor da PB em $B$. brizantha decresce representada por uma regressão quadrática do $2^{\circ}$ grau onde os menores valores ocorreram ao redor de 270 dias de crescimento, momento coincidente com o final das "secas" (início de setembro). 
Tabela 3. Composição químico-bromatológica e digestibilidade máxima e mínima em pastagens diferidas, no momento da utilização

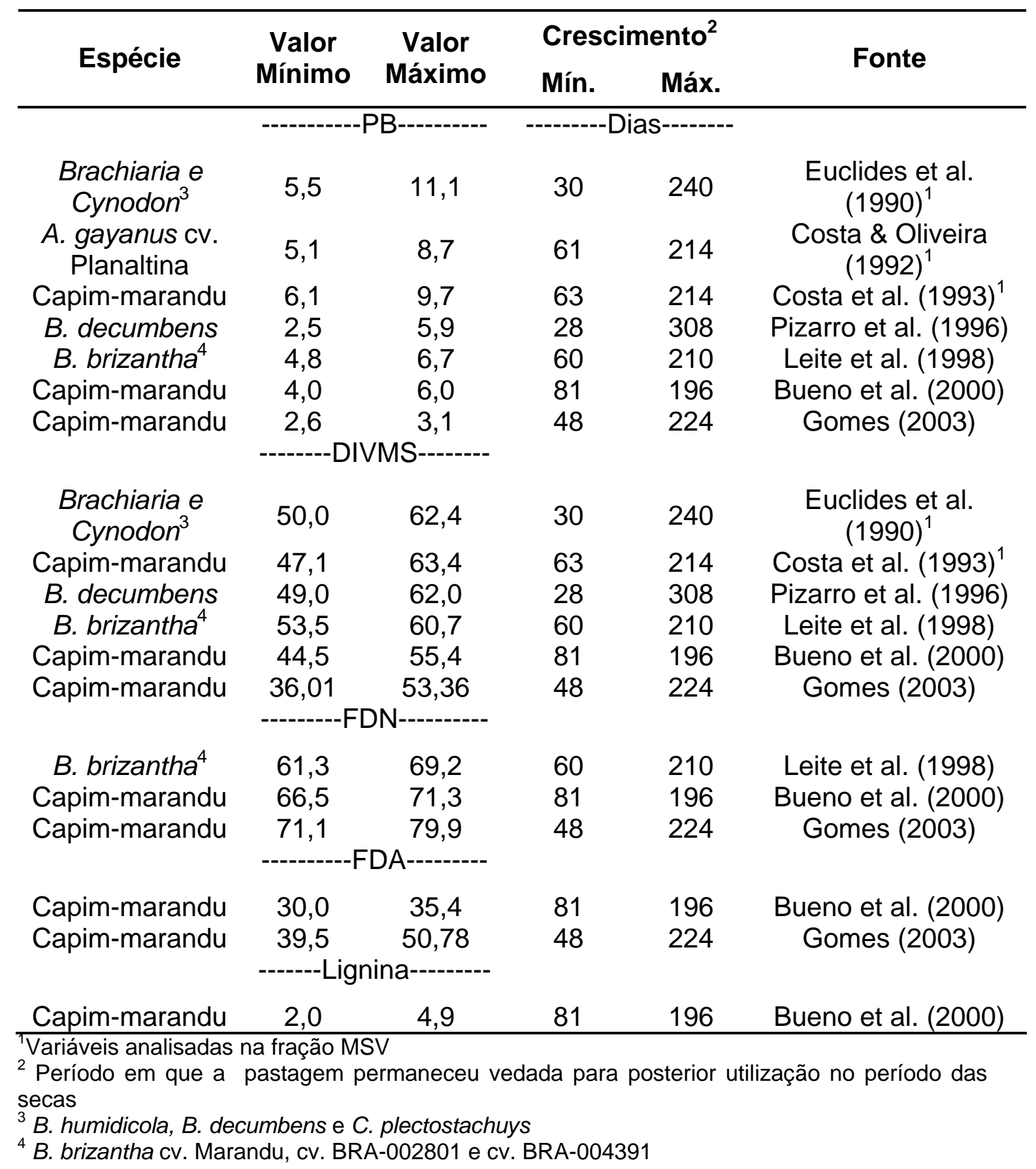

A DIVMS foi afetada pela época de utilização (Pizarro et al., 1996; Leite et al., 1998; Gomes, 2003), variando entre $36 \%$ e 53\% em setembro, 
independentemente do momento de vedação da pastagem. Já nos resultados de Euclides et al. (1990), Costa et al. (1993) e Bueno et al. (2000) houve interação entre momentos de vedação e utilização, sendo que os valores de DIVMS foram decrescentes com o aumento dos períodos vedados da pastagem.

No caso das frações da parede celular, a tendência é inversa ao observado para PB e DIVMS e semelhante à da massa de forragem, onde maiores períodos de descanso da planta resultam em maiores teores de fibra, representados pelos valores máximos de FDN, FDA e Lignina (Tabela 3). Os teores máximos de FDN obtidos por Gomes (2003), por volta de $80 \%$, são decorrentes dos tratamentos vedados em janeiro, enquanto que no trabalho de Leite et al. (1998) os maiores teores dessa fração, ao redor de $69 \%$, ocorreram nas avaliações de setembro.

Além dos aumentos nos teores de FDN, FDA e Lignina com a maturidade da planta, alterações entre suas proporções também são verificadas. Reis (2000), estudando a composição químico-bromatológica de $B$ brizantha em diferentes idades de corte, verificou aumentos lineares para FDA e Lignina, enquanto que para a FDN o aumento foi quadrático, com o ponto de máximo coincidindo com os 270 dias de crescimento (início de setembro). Além disso, nesse trabalho o ritmo de aumento dos teores de FDA e Lignina foram maiores que as FDN durante todo o período, e a partir dos 60 dias de avaliação, respectivamente. Sendo assim, além dos aumentos no teor de fibra da forragem, a composição dessa fibra também sofreu alterações, com uma participação crescente da FDA e, principalmente, da lignina, em detrimento das frações solúveis em detergente ácido.

O uso de novos modelos matemáticos, tanto para estimativa de NDT, como o proposto por Weiss et al. (1992), quanto para predição de desempenho e consumo animal, através de programas de otimização como o CNCPS (Cornell Net Carbohydrate and Protein System; Fox, et al., 1992) têm demandado um detalhamento da composição da planta maior que aquele 
oferecido pelos componentes químico-bromatológicos presentes na Tabela 3. O CNCPS é fundamentado basicamente nas diferentes taxas de degradação das frações nitrogenadas e de carboidratos estruturais da pastagem (Sniffen et al., 1992). O desempenho animal seria então dependente de um balanço entre o sincronismo das taxas de degradação dessas frações e sua fração disponível, em detrimento de seus valores brutos, o que resultaria em uma maximização da fermentação ruminal e produção microbiana no rúmen.

Dessa forma o estudo de frações nitrogenadas, principalmente aquelas aderidas à FDN e FDA (NFDN e NFDA, respectivamente), são de grande importância, uma vez que elas representam as frações indegradáveis (NFDA) ou de degradação mais lenta no rúmen (NFDN; Sniffen et al., 1992). Essas frações têm participação crescente com o aumento da maturidade da planta (Reis, 2000), o que torna importante sua determinação em pastagens diferidas. A mesma ênfase deve ser dada para a lignina uma vez que sua associação com a celulose e, principalmente, hemicelulose resulta em redução na disponibilidade das mesmas para o animal (Van Soest, 1994), aumentando a fração indigestível da FDN (Traxler et al., 1998).

Dessa forma, a avaliação da planta forrageira seria mais completa se fossem estudadas as frações de fibra e as de proteína, principalmente aquelas ligadas à fibra, de modo a definir a quantidade de nutrientes, passiveis de serem aproveitados pelo animal em pastejo. Estudos relativos ao diferimento de pastagens tropicais abordando a avaliação dessas frações no decorrer da utilização da pastagem são escassos na literatura, assim como a avaliação da dieta selecionada pelos animais ao longo do período de utilização da pastagem, uma vez que os dados encontrados (Tabela 3) são obtidos através da análise de todo o estrato da pastagem coletado através de cortes no momento em que os animais iniciariam o pastejo.

A avaliação desses componentes durante o período de utilização do pasto diferido permitiria simulações mais precisas relativas ao consumo e desempenho dos animais, como demonstrado por Balsalobre (2002) estudando 
o capim Tanzânia sob lotação rotacionada. Esse autor determinou que o consumo de forragem variou e $6,58 \%$ a $7,42 \%$ em relação ao peso metabólico quando o resíduo pós pastejo foi de $1000 \mathrm{e} 4000 \mathrm{~kg} \mathrm{MSV} \mathrm{ha}^{-1}$. O consumo de forragem também foi estimado em relação à composição de FDN da forragem, sendo essa fração consumida em média ao nível de 1,34\% do PV.

\subsubsection{Valor nutritivo da dieta selecionada pelo animal}

A determinação do valor nutritivo da forragem em oferta através de análises químico-bromatológicas (Tabela 3) pode ser insuficiente para estimar o desempenho dos animais, uma vez que não considera o pastejo seletivo dos mesmos. Sabe-se que os animais em pastejo sempre que podem, exercem seletividade, sendo essa uma ferramenta importante para melhorar o valor nutritivo da forragem ingerida em relação àquela ofertada. A Figura 5 e a Tabela 4 mostram que os animais selecionam em sua dieta preferencialmente as folhas, depois as hastes e finalmente o material morto, resultando em melhor valor nutritivo que a forragem ofertada para consumo (Chacon \& Stobbs, 1976; Lourenço \& Lascano, 1988; Euclides et al., 1992; Pereira et al., 1992; Barcellos \& Andrade, 1993; Camarão et al., 1994).

No entanto, apesar da constante superioridade da dieta selecionada em relação à ofertada, mudanças na composição botânica e na massa de forragem podem alterar a grandeza dessa seletividade. Barcellos \& Andrade (1993) verificaram que o tratamento com maior taxa de lotação (1,4 UA.ha $\left.{ }^{-1}\right)$ comparado às taxas de lotação de 0,8 a 1,2 UA.ha-1 resultou em menor proporção de folhas verdes ingerida pelo animal (55\% e 58\% para as taxas de lotação de 1,4 e 1,0 UA.ha ${ }^{-1}$, respectivamente). Nesse trabalho a redução na participação de folhas verdes na dieta não prejudicou o desempenho diário dos animais, que foi de 180 e 190 g.dia $^{-1}$ para os tratamentos representados pelas taxas de lotação de 0,8 e 1,4 UA.ha- ${ }^{-1}$, respectivamente. 
Tabela 4. Composição botânica da forragem ofertada e da dieta selecionada em pastagens de $B$. humidicola ao longo do ano

\begin{tabular}{|c|c|c|c|c|c|c|c|}
\hline \multirow[b]{2}{*}{ Mês } & \multicolumn{3}{|c|}{----Forragem Ofertada---- } & \multicolumn{4}{|c|}{----------Dieta Selecionada---------- } \\
\hline & Folha & Colmo & $\begin{array}{c}\text { Material } \\
\text { Morto }\end{array}$ & Folha & Colmo & $\begin{array}{c}\text { Material } \\
\text { Morto }\end{array}$ & $\begin{array}{c}\text { Outras } \\
\text { Plantas }\end{array}$ \\
\hline & ------- & -1- & -- & $\%$ da MS & -1---- & $\overline{-\cdots---}$ & 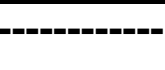 \\
\hline JAN & 39,3 & 37,0 & 23,7 & 86,9 & 7,6 & 3,1 & 2,4 \\
\hline FEV & 44,2 & 39,3 & 16,6 & 85,3 & 9,9 & 1,3 & 3,5 \\
\hline MAR & 41,0 & 45,5 & 13,5 & 86,3 & 9,0 & 2,2 & 2,5 \\
\hline$A B R$ & 39,2 & 45,1 & 15,7 & 79,9 & 15,0 & 2,5 & 2,6 \\
\hline MAI & 41,1 & 42,0 & 16,9 & 77,5 & 17,1 & 3,7 & 1,7 \\
\hline JUN & 42,6 & 41,8 & 15,6 & 73,7 & 21,3 & 2,1 & 2,9 \\
\hline JUL & 38,6 & 39,3 & 22,1 & 77,0 & 12,7 & 4,6 & 5,7 \\
\hline AGO & 34,3 & 31,2 & 34,5 & 77,4 & 16,4 & 3,9 & 2,3 \\
\hline SET & 34,3 & 28,6 & 37,1 & 76,0 & 16,2 & 3,6 & 4,2 \\
\hline OUT & 37,3 & 31,7 & 31,0 & 82,2 & 12,8 & 1,3 & 3,7 \\
\hline NOV & 39,4 & 32,6 & 28,0 & 81,3 & 12,5 & 3,4 & 2,8 \\
\hline DEZ & 46,2 & 32,6 & 21,2 & 85,3 & 11,3 & 1,1 & 2,3 \\
\hline
\end{tabular}

Fonte: Camarão et al. (1994)

Por outro lado, Pereira et al. (1992), também trabalhando com variações nas taxas de lotação não verificaram efeito sobre a dieta selecionada, o que poderia ser explicado pela alta oferta de forragem por animal utilizada no experimento, acima dos $9 \%$. Sendo assim, a oferta de forragem é ferramenta muito mais eficiente que a taxa de lotação para determinar as mudanças no padrão seletivo dos animais em pastejo, desde que o período de utilização da pastagem seja pré-determinado. 
A

B

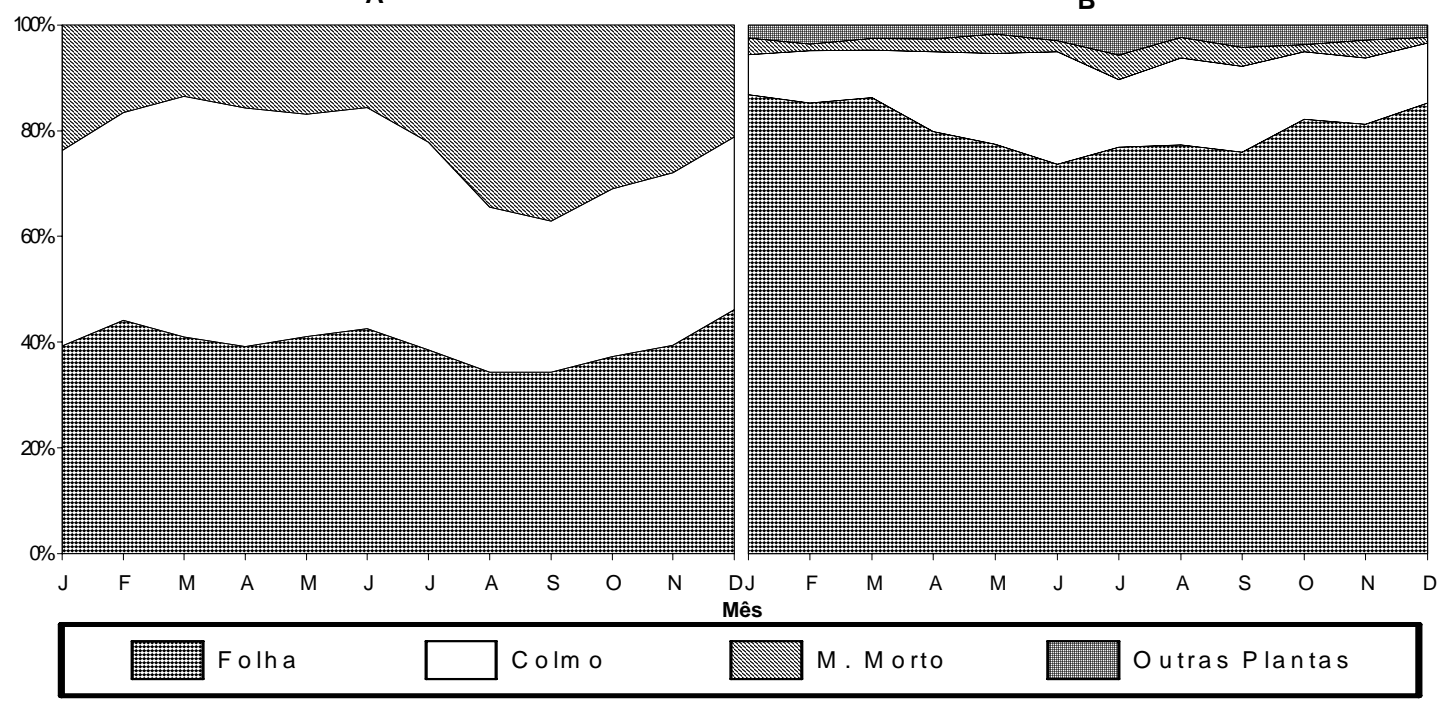

Figura 5 - Fracionamento da composição botânica da forragem disponível (A) e da dieta ingerida pelo animal (B) ao longo do ano

Fonte: Camarão et al. (1994)

A duração do período de pastejo, juntamente com a estacionalidade de crescimento da planta forrageira, promovem mudanças na composição botânica do dossel e, conseqüentemente, alterações das frações ingeridas pelo animal em pastejo. Chacon \& Stobbs (1976) determinaram a participação de folhas, hastes e material senescido na dieta do animal ao longo de 15 dias de pastejo em Setaria anceps cv. Kazungula após 9 semanas de crescimento. A proporção de folhas na dieta foi de cerca de $100 \%$ e $56 \%$ para o primeiro e $15^{\circ}$ dia de pastejo, respectivamente, enquanto que, nesse período, a participação desse componente na forragem ofertada caiu de $35 \%$ para $7,5 \%$.

Barcellos \& Andrade (1993), trabalhando com A. gayanus, detectaram que as maiores participações de folhas verdes na dieta foram nos meses de outubro a março, quando compuseram mais de $75 \%$ da dieta. À medida que o período de crescimento avançou para o inicio do "inverno", a participação de folhas verdes na dieta caiu para $4,4 \%$, enquanto as de folhas secas e de hastes representaram $63,4 \%$ e $20,3 \%$, respectivamente. Nesse estudo os teores de PB e DIVMS da dieta acompanharam a tendência de decréscimo. 
Resultados semelhantes foram obtidos por Euclides et al. (1992) trabalhando com $B$. decumbens e Camarão et al. (1994) utilizando a $B$. humidicola. Euclides et al. (1992) mostraram que a participação de MSV na dieta foi de $90 \%$ e $30 \%$ para o "verão" e "inverno", respectivamente, enquanto que o material verde representava de $26 \%$ a $2,5 \%$ da forragem ofertada. Por outro lado, Camarão et al. (1994) indicaram que a dieta era composta por $87 \%$ e $73,7 \%$ de folhas para o "verão" e "inverno", respectivamente, embora isso representasse apenas $46,2 \%$, e $34,3 \%$ do material ofertado naqueles períodos de pastejo, respectivamente (Figura 5).

As diferenças nos teores de PB e na DIVMO também seguiram comportamento semelhante. Os teores protéicos da dieta no "verão" e "inverno" e da forragem ofertada nesses mesmos períodos foram, respectivamente, de 9,8\%, 5,1\%, 4,0 e 2,0\% (Euclides at al., 1992), e de 8,7\%, 7,1\%, 7,8\% e 5,9\% no estudo de Camarão et al. (1994). As DIVMO foram, de 62,1\% e 45,9\% para a dieta no "verão" e "inverno", respectivamente, enquanto que na forragem ofertada esses valores foram de 32,2\% e $41,7 \%$ respectivamente (Euclides at al., 1992).

Para a B. humidicola estudada por Camarão et al. (1994), a dieta apresentava valores de DIVMO de 58,8\% e 51,0\% para o "verão" e "inverno", enquanto que o material em oferta possuía $56,5 \%$ e $41,6 \%$, respectivamente.

No trabalho de Camarão et al. (1994), onde a dieta selecionada pelo animal apresentava valor nutritivo superior até mesmo que a fração da forragem ofertada composta somente por folhas verdes, fica clara a capacidade do animal selecionar dentro das frações que compõem a planta, mesmo que essa seja o componente mais nutritivo do dossel. Esse fato pode ser justificado pela estrutura das folhas e do dossel. As folhas mais novas são as mais nutritivas e com maior facilidade de preensão pelo animal. As folhas mais velhas, além de apresentarem menor valor nutritivo, são de acesso mais difícil para o consumo.

Resultados semelhantes foram obtidos por Euclides et al. (1992) com $B$. humidicola e $A$. gayanus. Nesse trabalho os autores concluíram que a fração 
foliar não é método adequado para se estimar o valor nutritivo da dieta de bovinos em pastejo. A seletividade do animal melhora consideravelmente a qualidade da dieta comparada à forragem em oferta, mesmo que essa seja constituída somente por folhas.

Nesse contexto, métodos de amostragem de forragem de modo a representar a porção ingerida pelo animal se fazem necessários. Existe um consenso entre os autores favorecendo o uso de animais com fístula esofágica, uma vez que o pastejo estaria sendo feito pelo próprio animal (Lourenço \& Lascano, 1988; Euclides et al., 1992; Pereira et al., 1992; Barcellos \& Andrade, 1993; Camarão et al., 1994). Por outro lado, essa técnica apresenta limitações como a contaminação do material amostrado com saliva, o que pode alterar principalmente os teores de $\mathrm{PB}$, e a necessidade de vários animais fistulados, objetivando minimizar os efeitos de variação de seleção entre animais (Euclides et al., 1992).

Euclides et al. (1992), estudando técnicas de amostragem da forragem pastejada determinaram que o pastejo simulado, isto é, a colheita seletiva de forragem na tentativa de reproduzir o pastejo efetuado pelos animais, não apresentou diferenças em relação à extrusa obtida pelo uso da fístula esofágica. Outras técnicas de amostragem como forragem total disponível, estrato superior do dossel, e amostras estratificadas a cada $10 \mathrm{~cm}$ não refletiram a dieta consumida pelo animal observada na extrusa.

\subsubsection{Adubação de áreas diferidas no momento da vedação}

Durante o dimensionamento da área a ser vedada, é necessário considerar que o restante da propriedade será submetido a uma intensidade de pastejo mais elevada durante o período de diferimento. Sem dúvida esse planejamento assume maior importância pelo fato de que o diferimento ocorre quando as condições climáticas não são as mais favoráveis às máximas taxas 
de crescimento das plantas forrageiras. $\mathrm{O}$ uso de pastagens diferidas deve ser visto então de maneira integrada na propriedade, ou seja, o dimensionamento da área destinada a essa técnica deve contemplar a necessidade de forragem para as "secas" e as "águas".

Assim, o uso de fertilizantes em pastagens diferidas aceleraria o ritmo de crescimento da planta, compensando ocasionais atrasos no início do diferimento, promoveria incrementos na produção de forragem (quando não ocorre atraso no momento de vedação), e diminuiria a dimensão da área a ser diferida.

Adubações nitrogenadas merecem destaque para atender os objetivos apontados visto que as plantas forrageiras tropicais são responsivas a adição de elevadas doses desse nutriente, sendo as respostas lineares até patamares superiores a $400 \mathrm{~kg} \mathrm{~N} \cdot \mathrm{ha}^{-1}$.ano ${ }^{-1}$, quando as condições climáticas e edáficas são favoráveis ao crescimento (Vicente-Chandler et al., 1959; Vicente-Chandler et al., 1962; Vicente-Chandler, 1973). Além disso, a adição de $\mathrm{N}$ ao sistema promove a potencialização do uso de outros nutrientes, como o P (Quinn et al., 1961) e o K (Andrade et al., 2000).

Quanto às respostas das plantas forrageiras à adubação nitrogenada, existe uma amplitude larga de valores variando de 5 a $89 \mathrm{~kg} \mathrm{MS.kg} \mathrm{N}$ aplicado $^{-1}$ (Balsalobre et al. 2002), estando normalmente esses valores concentrados na faixa de 40 a $70 \mathrm{~kg} \mathrm{MS.kg} \mathrm{N}$ aplicado $^{-1}$ (Corsi \& Nussio, 1994). Balsalobre et al. (2002) justifica que tal variação é decorrente de fatores como espécie forrageira, fonte do nutriente, tempo de rebrota, dosagem de adubo aplicado, condições climáticas, estádio de desenvolvimento da planta e fertilidade do solo.

Alguns trabalhos foram realizados no sentido de se avaliar o uso da adubação nitrogenada como ferramenta para diminuição da estacionalidade de produção forrageira. Werner (1970/71) e Costa (1999) trabalharam com Capimcolonião e B. humidicola, respectivamente, sendo que em ambos os casos a adubação em março promoveu aumentos de produção de forragem no período 
de "inverno" e redução da estacionalidade de produção. No entanto, apesar da melhor distribuição de forragem ao longo do ano, as diferenças entre produção de "águas" e "secas" ainda foram significativas e desfavoráveis para o período crítico de produção de forragem quando se produziu durante as "secas" 20\% da produção anual. Deve-se ainda considerar que as produções anuais de massa seca de forragem foram baixas, ao redor de 6.800 e $1.695,3 \mathrm{~kg} \mathrm{ha}^{-1}$ para os trabalhos de Werner (1970/71) e Costa, (1999), respectivamente.

Avaliando o beneficio:custo do uso dessa estratégia de adubação parece que ela não é favorável. Entretanto, a baixa eficiência de uso do $\mathrm{N}$ nesses trabalhos pode ter ocorrido devido à freqüência relativamente alta entre cortes, que ocorreram entre 55 e 60 dias, uma vez que Euclides et al. (1990) apontaram que pastagens vedadas a partir de março necessitaram de período mais longo de crescimento para acumular forragem. Vicente-Chandler et al. (1959) também indicaram que períodos mais longos de crescimento proporcionaram melhores eficiências no uso do nitrogênio quando avaliadas em $\mathrm{kg} \mathrm{MS.kg} \mathrm{N}$ aplicado $^{-1}$. Esses autores mostraram para três gramíneas tropicais (Pennisetum purpureum, Panicum maximum e Panicum purpurascens) que cada $\mathrm{kg}$ de $\mathrm{N}$ aplicado proporcionou 30,4; 48,0 e 62,4 kg MS, para freqüências de desfolha de 40, 60 e 90 dias, respectivamente.

Essas informações sugerem que o uso do fertilizante nitrogenado associado à menor freqüência de desfolha é capaz de produzir mais forragem. Esse conceito norteia a recomendação de adubação nitrogenada no momento da vedação da pastagem como estratégia para acúmulo de forragem (Euclides \& Queiroz, 2000; Martha Júnior \& Balsalobre, 2001), uma vez que o período de vedação é geralmente da ordem de 90 a 120 dias.

De maneira geral, quanto maiores as doses de nitrogênio empregadas no sistema, menores serão suas conversões em produção de forragem (Primavesi et al., 2001b; Werner et al., 1967). Além disso, fatores ambientais como fotoperíodo e temperatura decrescentes, assim como escassez de chuvas também afetam negativamente as respostas das plantas forrageiras à 
adubação nitrogenada, tanto restringindo o crescimento do capim quanto impedindo melhor eficiência de uso desse fertilizante.

Euclides \& Queiroz (2000) e Martha Júnior \& Corsi (2001) preconizaram adubações de 40 a $80 \mathrm{~kg}$ de N.ha-1 no momento do diferimento. Esses autores apontaram que se deve dar preferência para adubar áreas de melhor fertilidade do solo para obtenção de resultados melhores do uso da adubação nitrogenada.

\subsubsection{Fontes de $\mathbf{N}$}

Apesar de ser recomendado o uso da adubação nitrogenada no momento da vedação dos pastos, Martha Júnior \& Balsalobre (2001), salientaram a necessidade de mais estudos relativos às fontes desse nutriente no sentido de permitir práticas de adubação mais efetivas, confiáveis e econômicas, uma vez que estas diferem entre si em suas características agronômicas (Tabela 5).

De maneira geral, os fertilizantes nitrogenados caracterizam-se pelo elevado índice salino, elevada solubilidade e elevado poder acidificante do solo. Dentre os fertilizantes nitrogenados listados na Tabela 5, merecem maior destaque o nitrato de amônio, o sulfato de amônio e, principalmente a uréia. Essa fonte de nitrogênio merece destaque pois é consumida em maior quantidade que as demais (Figura 6), uma vez que apresenta vantagens econômicas tanto durante o processo de produção, quanto no de transporte dado sua concentração elevada de nitrogênio. O custo energético de produção de $1 \mathrm{~kg}$ de $\mathrm{N}$ na forma de uréia é de 15,2 Mcal, enquanto que o de sulfato de amônio é de 22,5 Mcal (Vitti et al., 1984).

Devido aos menores custos de produção e transporte, a uréia tem sido a fonte de fertilizante nitrogenado preferida por produtores como mostra a Figura 6. Por outro lado, avaliações quanto à sua eficiência de uso em relação aos sais amoniacais, principalmente em condição de diferimento de pastagens, precisam 
ser realizadas, uma vez que estudos abordando esse aspecto da adubação nitrogenada em pastagens diferidas não foram encontrados na literatura, com exceção do trabalho de Paulino et al. (1995), onde se verificou diferença entre

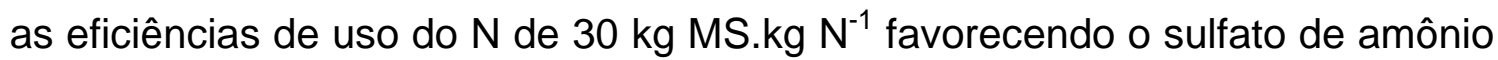
em relação à uréia aplicados no momento da vedação da pastagem.

Tabela 5. Características agronômicas das fontes de nitrogênio encontradas no mercado

\begin{tabular}{|c|c|c|c|c|c|}
\hline Fontes de $\mathrm{N}$ & Fórmula & $\% \mathbf{N}$ & I. Salino ${ }^{A}$ & $\begin{array}{l}\text { Eq. em } \\
\mathrm{CaCO}_{3}{ }^{\mathrm{B}}\end{array}$ & $\begin{array}{c}\text { Solubilidade } \\
\text { g/ } 100 \mathrm{~mL}\end{array}$ \\
\hline Uréia & $\mathrm{CO}\left(\mathrm{NH}_{2}\right)_{2}$ & 45 & 75 & -840 & 119 \\
\hline $\begin{array}{c}\text { Sulfato de } \\
\text { Amônio }\end{array}$ & $\left(\mathrm{NH}_{4}\right)_{2} \mathrm{SO}_{4}$ & 21 & 69 & -1100 & 71 \\
\hline $\begin{array}{l}\text { Nitrato de } \\
\text { Amônio }\end{array}$ & $\mathrm{NH}_{4} \mathrm{NO}_{3}$ & 33 & 105 & -590 & 187 \\
\hline $\begin{array}{l}\text { Nitrato de } \\
\text { cálcio }\end{array}$ & $\mathrm{Ca}\left(\mathrm{NO}_{3}\right)_{2}$ & 26 & 61 & -280 & - \\
\hline $\begin{array}{l}\text { Nitrato de } \\
\text { Sódio }\end{array}$ & $\mathrm{NaNO}_{3}$ & 16 & 100 & - & 73 \\
\hline $\begin{array}{l}\text { Nitrato de } \\
\text { Potássio }\end{array}$ & $\mathrm{KNO}_{3}$ & 13 & - & +235 & 31 \\
\hline Calcianamida & $\mathrm{C}_{\mathrm{a}} \mathrm{CN}_{2}$ & 20,5 & - & - & \\
\hline MAP & $\mathrm{NH}_{4} \mathrm{H}_{2} \mathrm{PO}_{4}$ & 11 & 30 & -650 & 40 \\
\hline DAP & $\left(\mathrm{NH}_{4}\right)_{2} \mathrm{HPO}_{4}$ & 18 & 34 & -625 & 71 \\
\hline
\end{tabular}




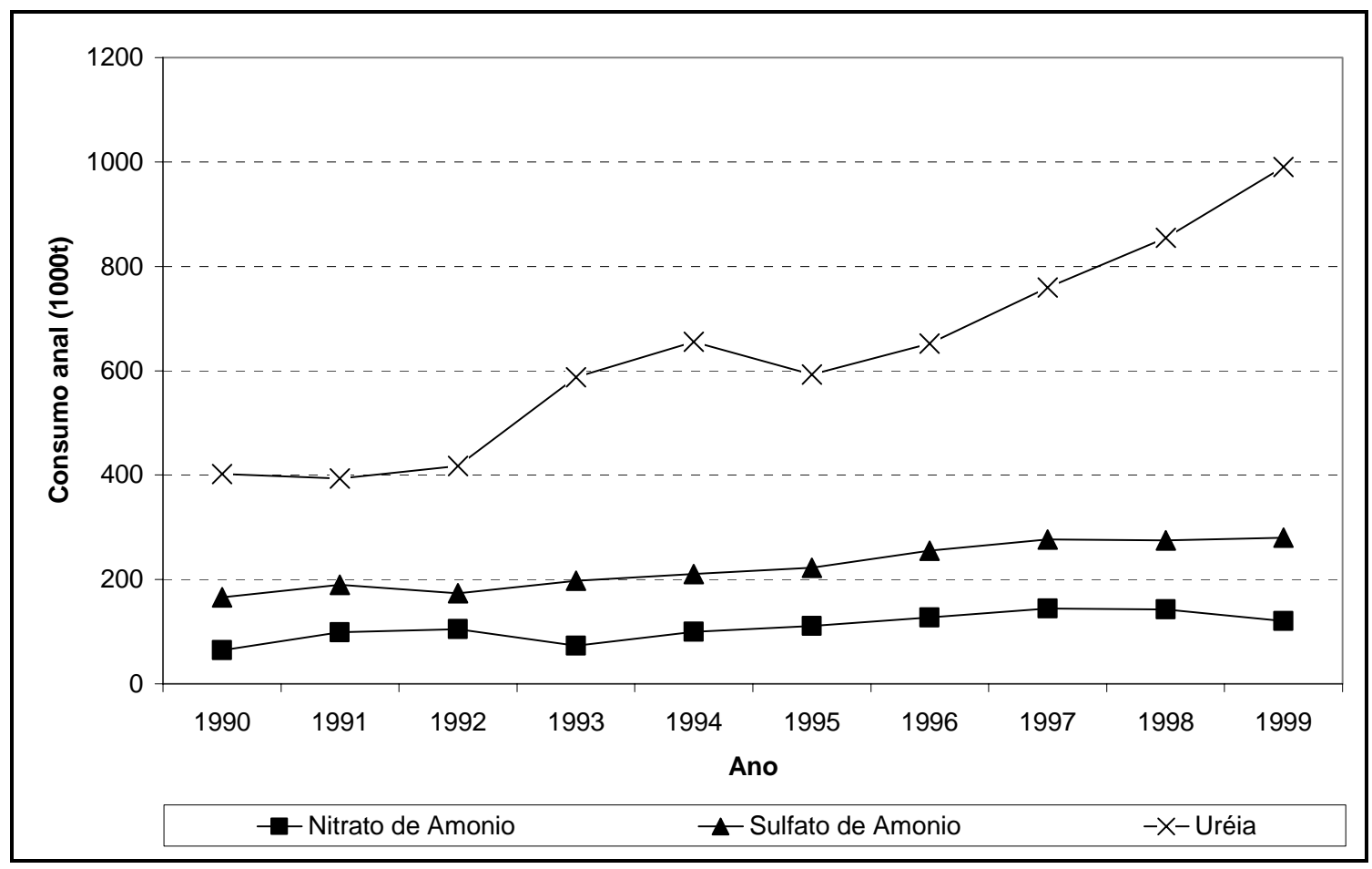

Figura 6 - Consumo anual de uréia, sulfato de amônio e nitrato de amônio no Brasil durante a década de 90 Fonte: FAO (2004)

\subsubsection{Vias de perdas do $\mathrm{N}$ aplicado via fertilizante no sistema solo-planta}

O fertilizante nitrogenado aplicado na pastagem, pode ter diferentes destinos: ser recuperado pela planta, permanecer no solo, ficar imobilizado no liter ou liteira, e ser perdido do sistema solo-planta (Corsi \& Martha Júnior, 1997; Martha Júnior, 1999). Dificilmente a eficiência 100\% do fertilizante aplicado nas culturas agrícolas é conseguida, independente da fonte nitrogenada utilizada.

Quanto às perdas de nitrogênio do sistema, o conhecimento e quantificação dessas vias devem ser determinados para se estabelecer estratégias visando aumentar a eficiência de uso desse nutriente e minimizar o impacto ambiental do mesmo (Martha Júnior, 2003). As perdas de nitrogênio do 
sistema solo-planta podem ocorrer através da desnitrificação; da lixiviação de $\mathrm{N}-\mathrm{NO}_{3}{ }^{-}$; da volatilização de $\mathrm{N}-\mathrm{NH}_{3}$; e da erosão do solo e escorrimento superficial, podendo esta ser desprezada.

As perdas por lixiviação, conforme indicado pela presença de ${ }^{15} \mathrm{~N}$ em diferentes profundidades do solo, não são significativas em ambientes de pastagens bem manejadas (Martha Júnior, 1999; Oliveira, 2001). Esses estudos indicaram perdas inferiores a $5 \%$ do $\mathrm{N}$ proveniente do fertilizante, em profundidades ao redor de $30 \mathrm{~cm}$. Justificam-se esses baixos níveis de perdas por lixiviação devido ao fato de que os solos sob pastagens, de maneira geral, são profundos e vegetados por plantas forrageiras de elevada capacidade de extração de nutrientes (Martha Júnior \& Vilela, 2002).

As perdas de $\mathrm{N}$ por lixiviação são consideráveis em solos de baixa CTC, rasos, em ambientes de elevada precipitação e condições de pastagens mal manejadas. Nessa situação o caminhamento do $N$ no perfil do solo é potencializado e a capacidade da planta em recuperar esse nutriente diminuída (Corsi et al., 2000).

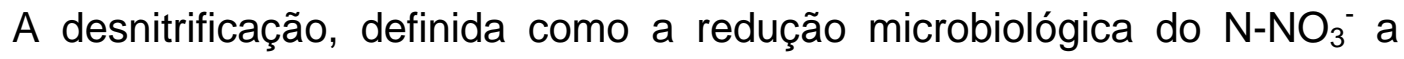
$\mathrm{N}_{2} \mathrm{O}$ e NO, é afetada por fatores do solo, sendo os principais a estrutura e textura, conteúdo de água, concentração e forma de $\mathrm{N}$ mineral (Arah et al., 1991). Esses fatores influenciam na disponibilidade de $\mathrm{O}_{2}$ no sistema, além de determinar o estoque de $\mathrm{N}$ disponível para o processo.

Em revisão sobre o assunto, Martha Júnior (2003) reportou perdas que variaram de 2 a $7 \%$ do $\mathrm{N}$ aplicado devido à desnitrificação, podendo esses valores em alguns casos chegarem ao redor de 20\%. Esse autor também comentou que o problema da desnitrificação merece maior atenção em situações de pastagens irrigadas, uma vez que estas estão mais sujeitas à anaerobiose e compactação do solo. Veldkamp et al.(1998) relataram que as perdas por desnitrificação em ambientes que fazem uso de baixas quantidades de fertilizantes nitrogenados, como no caso do diferimento de pastagens, onde as doses aplicadas situam-se abaixo dos $100 \mathrm{~kg} \mathrm{~N}$.ha ${ }^{-1}$, são pequenas. 
As perdas de $\mathrm{N}$ através da lixiviação e desnitrificação parecem não ser representativas em ambientes de pastagens bem manejadas e vegetadas sobre solos profundos e bem drenados, representando valores ao redor de $5 \%$ (Martha Júnior, 1999; Primavesi et al., 2001b; Martha Junior, 2003).

Entretanto as perdas por volatilização podem interferir na economicidade do processo, como apontam trabalhos de Trivelin et al. (1994), Martha Júnior (1999) e Primavesi et al. (2001b).

\subsubsection{Fatores que influenciam as perdas de $\mathbf{N}$ por volatilização}

A volatilização de amônia ocorre quando há o suprimento de $\mathrm{NH}_{3}$ próximo à superfície do solo, o que possibilita a transferência desse gás para a atmosfera. A freqüência ou taxa com que esse processo ocorre depende de fatores climáticos, de solo, de manejo, bem como da interação entre eles (Ernst \& Massey, 1960; Anjos \& Tedesco, 1973; Kiehl, 1989; Trivelin et al., 1994). Dentre as alternativas de manejo que podem interferir nas perdas de $\mathrm{N}-\mathrm{NH}_{3}$ por volatilização, destacam-se a localização de aplicação do fertilizante, a dose e a fonte de $\mathrm{N}$ utilizada.

Existe um consenso entre os autores de que sais amoniacais, como o nitrato e sulfato de amônio, são mais eficazes que a uréia em relação as perdas de $\mathrm{N}-\mathrm{NH}_{3}$ por volatilização (Trivelin et al., 1994; Martha Júnior, 1999; Primavesi et al., 2001). Enquanto os sais amoniacais apresentam perdas por volatilização freqüentemente entre 5 e $10 \%$ do $\mathrm{N}$ total aplicado, a uréia perde, normalmente, ao redor de 10 a 25\%, podendo atingir, em condições propícias, até $80 \%$.

De maneira geral, quando o adubo nitrogenado, em especial a uréia, é incorporado no solo a uma profundidade ao redor de $5 \mathrm{~cm}$, observa-se uma redução significativa das perdas por volatilização, quando comparadas com a aplicação a lanço em superfície (Ernst \& Massey, 1960; Anjos \& Tedesco, 1973; Vitti et al., 1984; Rodrigues \& Kiehl, 1992). Entretanto, esse tipo de prática não 
é recomendada em ambientes de pastagens, uma vez que pode haver danos ao sistema radicular das plantas, prejudicando a sua rebrota (Corsi \& Nussio, 1994).

Quanto às doses de fertilizante aplicadas, tem-se constatado que, freqüentemente, maiores doses de fertilizante resultam em maiores perdas de $\mathrm{N}-\mathrm{NH}_{3}$ por volatilização (Kiehl, 1989; Trivelin et al., 1994; Primavesi et al., 2001a). Em relação aos fatores de solo, merecem maior atenção o pH, a CTC e o teor de matéria orgânica (MO). $\mathrm{A} \mathrm{NH}_{3}$ ou $\mathrm{NH}_{4}{ }^{+}$no solo estão em equilíbrio dinâmico representado pela equação (1), sendo $\mathrm{o} p \mathrm{pH}$ do solo o fator que determina o deslocamento dessa reação, podendo interferir nas perdas de $\mathrm{N}$ $\mathrm{NH}_{3}$ por volatilização (Ernst \& Massey, 1960; Anjos \& Tedesco, 1973).

$$
\begin{array}{cc}
\mathrm{NH}_{4}{ }^{+}+\mathrm{OH}^{-} & \rightleftarrows \mathrm{NH}_{3}+\mathrm{H}_{2} \mathrm{O} \\
\mathrm{pH}<7,0 & \mathrm{pH}>7,0
\end{array}
$$

Apesar das fontes nitrogenadas serem geralmente acidificantes do solo, a uréia, no momento de sua dissolução e hidrólise, eleva o pH do solo ao redor do grânulo (Vitti et al., 1984; Kiehl, 1989; Trivelin et al., 1994) favorecendo o deslocamento da equação (1) da direita e potencializando as perdas por volatilização.

A CTC do solo pode reter o $\mathrm{NH}_{4}{ }^{+}$, que se constitui na forma trocável do $\mathrm{N}$, e dessa maneira reduzir a sua disponibilidade na solução do solo, favorecendo a equação (1) no sentido para a esquerda. Isso explicaria porque solos de maior CTC são mais eficientes em manter o $\mathrm{N}$ aplicado no sistema solo-planta (Anjos \& Tedesco, 1973; Kiehl, 1989).

Existem resultados divergentes quanto à participação da matéria orgânica do solo nos processos de volatilização de $\mathrm{NH}_{3}$, uma vez que, ao mesmo tempo em que a MO está associada com a maior atividade da urease, enzima necessária para desencadear a hidrólise da uréia, ela também tem papel 
fundamental na composição e aumento da CTC do solo, principalmente no caso de solos intemperizados, como os encontrados no Brasil (Raij, 1991).

Variáveis climáticas como a umidade relativa do ar, intensidade do vento e a concentração de amônia na atmosfera podem estar envolvidas nos processos de volatilização, embora a temperatura do ar e o regime de chuvas da região mereçam maior destaque (Ernst \& Massey, 1960; Vitti et al., 1984). Aumentos na temperatura aumentam a atividade da urease e, conseqüentemente, a hidrólise da uréia; provocando incrementos nos teores de $\mathrm{NH}_{3}$ em relação ao $\mathrm{NH}_{4}{ }^{+}$. A temperatura também aumenta a solubilidade da $\mathrm{NH}_{3}$ em água e sua difusão, provocando maiores perdas por volatilização (Ernst \& Massey, 1960; Vitti et al., 1984; Trivelin et al., 1994).

A ocorrência de chuvas pode determinar redução nas perdas por volatilização, devido ao carreamento físico do fertilizante nitrogenado para camadas subsuperficiais do solo (Ernst \& Massey, 1960; Vitti et al., 1984; Rodrigues \& Kiehl, 1986). Por outro lado, caso o volume de chuvas não seja suficiente para provocar o deslocamento do fertilizante no perfil do solo, ou se ocorrerem chuvas antes da adubação, as perdas de $\mathrm{N}-\mathrm{NH}_{3}$ por volatilização serão potencializadas, devido à solubilização do fertilizante na superfície do solo (Ernst \& Massey, 1960), provocando maior susceptibilidade do mesmo às variações de temperatura ou $\mathrm{pH}$, por exemplo.

As adubações nitrogenadas no momento da vedação de pastagens estão sujeitas a perdas por volatilização, principalmente no caso da aplicação de uréia, uma vez que nessa época o cenário reflete uma situação de umidade residual no solo, temperaturas ainda elevadas (Figura 2) e final da ocorrência de chuvas (Figura 3). Estudos comparativos entre fontes de $\mathrm{N}$ para determinar a eficiência das adubações nitrogenadas em condições de pastagens diferidas podem oferecer alternativas econômicas nesse processo de manejo dos recursos forrageiros da propriedade. 


\subsubsection{Alternativas $\mathrm{p} /$ redução das perdas de $\mathrm{N}-\mathrm{NH}_{3}$ por volatilização}

De acordo com Vitti et al.(1984), vários são os meios disponíveis para se alcançar maiores eficiências técnicas e econômicas do fertilizante nitrogenado, em especial a uréia, podendo esses ser divididos em três grandes grupos: o tecnológico, o agrícola e o genético. Dentre os fatores considerados como tecnológicos, destacam-se o controle da disponibilidade de fertilizantes, através do uso de tecnologias como a uréia protegida, as variações no tamanho do grânulo do fertilizante e uso de substâncias capazes de controlar as reações do adubo nitrogenado no solo, como os inibidores de urease e da nitrificação. No entanto, segundo Vitti et al. (1984), essas técnicas aguardam soluções principalmente de ordem econômica.

Já os fatores genéticos estão relacionados com o desenvolvimento de variedades mais eficientes em absorver nitrogênio e converter esse nutriente em maiores produções de forragem. No entanto essa alternativa não é efetiva considerando o caso de pastagens já implantadas.

Quanto aos fatores agrícolas o uso de sais amoniacais, o parcelamento da aplicação, a localização do adubo, e a adição de cloretos e sulfatos, podem se constituir em meios eficientes para reduzir as perdas de $\mathrm{N}$ em pastagens.

O uso de fertilizantes incorporados ao solo tem limitações, como já discutido anteriormente, por interferir no sistema radicular e na velocidade de recuperação da planta forrageira (Corsi \& Nussio, 1994), principalmente em pastagens diferidas, onde a rebrota da planta já é retardada pelas condições climáticas limitantes ao crescimento.

A indicação de fertilizantes à base de sais amoniacais depende da eficiência dessas fontes em relação à uréia. Paulino et al. (1995), trabalhando com $B$. decumbens determinaram que o sulfato de amônio teve eficiência três vezes superior à da uréia na produção de forragem, representados por 45 e 16

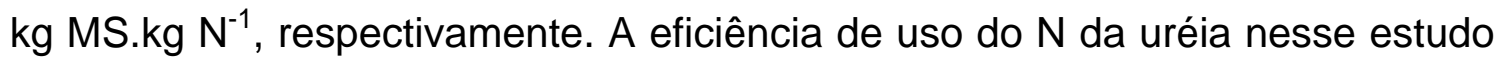


foi baixa comparada ao reportado por Martha Júnior \& Balsalobre (2001) que indicaram respostas médias na faixa de 25 a $35 \mathrm{~kg} \mathrm{MS}_{\mathrm{kg} \mathrm{N}} \mathrm{N}^{-1}$.

$\mathrm{O}$ uso da uréia associada com cloretos e sulfatos, como o $\mathrm{KCl}$ (Vitti et al., 1984), o $\mathrm{CaSO}_{4}$ (Vitti et al, 1984; Paulino et al., 1995) e o próprio (NH4) ${ }_{2} \mathrm{SO}_{4}$ (Vitti et al., 1984; Vitti, et al., 2002; Cantarella, 1998) pode se consistir em tecnologia capaz de reduzir as perdas de $\mathrm{N}$ pela volatilização, conforme as reações abaixo.

$$
\begin{aligned}
& \mathrm{CO}\left(\mathrm{NH}_{2}\right)_{2}+3 \mathrm{H}_{2} \mathrm{O} \stackrel{\text { urease }}{\longrightarrow}\left(\mathrm{NH}_{4}\right)_{2} \mathrm{CO}_{3} \cdot \mathrm{H}_{2} \mathrm{O} \\
& \left(\mathrm{NH}_{4}\right)_{2} \mathrm{CO}_{3} \longrightarrow \mathrm{H}_{2} \mathrm{O}+\mathrm{CO}_{2}+2 \mathrm{NH}_{3}^{\nearrow}(\mathrm{pH}>7,0)
\end{aligned}
$$

ou:

$$
\left(\mathrm{NH}_{4}\right)_{2} \mathrm{CO}_{3} \cdot \mathrm{H}_{2} \mathrm{O}+2 \mathrm{KCl} \longrightarrow \mathrm{K}_{2} \mathrm{CO}_{3}+2 \mathrm{NH}_{4} \mathrm{Cl}
$$

ou:

$$
\left(\mathrm{NH}_{4}\right)_{2} \mathrm{CO}_{3} \cdot \mathrm{H}_{2} \mathrm{O}+\mathrm{CaSO}_{4} \longrightarrow \mathrm{CaCO}_{3}+\left(\mathrm{NH}_{4}\right)_{2} \mathrm{SO}_{4}
$$

No caso da associação com sulfato de amônio, além da diminuição do $\mathrm{N}$ amídico na dose total (equação 6), reduzindo a susceptibilidade a perdas, ocorre uma maior acidificação do solo, proporcionando menores taxas por volatilização. Sendo assim, os íons $\mathrm{H}^{+}$liberados durante a reação de nitritação (equação 7) reduziriam a concentração do $\mathrm{OH}^{-}$liberado pela equação (1), formando água e gerando menos $\mathrm{NH}_{3}$ para ser volatilizado.

$$
\begin{aligned}
& (\mathrm{NH} 4)_{2} \mathrm{SO}_{4} \longrightarrow 2 \mathrm{NH}_{4}^{+}+2 \mathrm{SO}_{4}^{--} \\
& 2 \mathrm{NH}_{4}^{+}+3 \mathrm{O}_{2} \longrightarrow 2 \mathrm{NO}_{2}^{-}+4 \mathrm{H}^{+}+2 \mathrm{H}_{2} \mathrm{O}
\end{aligned}
$$

A associação de fertilizantes nitrogenados é feita através de cloretos ou sulfatos puros ou como elementos acompanhantes de outros fertilizantes, como seria o caso das combinações com superfosfato simples, que contém o $\mathrm{CaSO}_{4}$ 
em sua formulação. Oliveira (2001), em um trabalho estudando a recuperação de pastagens de $B$. decumbens concluiu que maiores produções de forragem foram obtidas quando o superfosfato simples foi aplicado parceladamente com o nitrogênio comparado a uma única aplicação do fertilizante fosfatado ao longo das épocas de adubação. Não foram encontrados na literatura estudos relativos à associação de fertilizantes buscando maior eficiência dos nutrientes em pastagens diferidas.

\subsection{Recuperação do nitrogênio aplicado}

A eficiência de uso de fertilizantes em pastagens diferidas pode ser obtida através da recuperação do mesmo pela planta, ou seja a quantidade de nutriente proveniente do fertilizante presente na planta em relação ao total aplicado. A quantificação da recuperação do adubo nitrogenado pode ser feita de maneira indireta (aparente) ou direta (real). A recuperação aparente é obtida quando uma parcela adubada com nitrogênio é comparada com outra que não recebeu o adubo, enquanto que a recuperação real é obtida através de traçadores, utilizando isótopos marcados como $0{ }^{15} \mathrm{~N}$, por exemplo. A recuperação real é mais precisa, uma vez que consegue distinguir o $\mathrm{N}$ proveniente do fertilizante daquele presente no solo ou originário da atmosfera, além de prover maiores detalhes sobre o movimento e transformações do $\mathrm{N}$ do fertilizante na planta forrageira (Martha Júnior, 1999; Martha Júnior, 2003). Entretanto, o custo elevado do nutriente marcado e das análises isotópicas limitam o seu uso em pesquisas.

O cálculo da recuperação aparente dos nutrientes tem a conveniência de ser de fácil execução e apresentar baixo custo, uma vez que apenas o teor de $\mathrm{N}$ total na planta, em adição à massa de forragem, precisam ser conhecidos. $\mathrm{A}$ desvantagem dessa técnica está na incapacidade de distinguir a origem do nutriente presente na planta, além de superestimar os valores reais (Martha 
Júnior, 2003), podendo estes ultrapassar a casa dos 100\% (Werner et al., 1967; Vitti, 1998). Entretanto, quando o objetivo da experimentação é simplesmente determinar a recuperação do $\mathrm{N}$ do fertilizante na parte aérea da pastagem e há possibilidade de se trabalhar com um tratamento controle, o método aparente seria mais adequado, conforme indicou Martha Júnior (2003). Valores de recuperação de $\mathrm{N}$ na parte aérea da planta para gramíneas forrageiras podem variar de 20 a 108\% (Werner et al. 1967; Corsi \& Nussio, 1994), sendo mais comuns na faixa de 40 a $60 \%$.

A recuperação aparente do nitrogênio aplicado consiste, portanto, em ferramenta eficaz no sentido de avaliar a eficiência de uso das diferentes fontes nitrogenadas no momento do diferimento da pastagem, como demonstrado por Paulino et al. (1995). Esses autores, em experimento testando diferentes fontes de $\mathrm{N}$ no momento do diferimento de $B$. decumbens, verificaram valores máximos de recuperação do $\mathrm{N}$ de $33 \%$ para a uréia e $49 \%$ para o sulfato de amônio em plantas forrageiras colhidas com 117 e 89 dias, respectivamente. Independente da fonte utilizada, os menores valores de recuperação do N, inferiores a 10\%, ocorreram em setembro, quando a planta tinha 173 dias de crescimento livre.

Pela revisão apresentada, observa-se que a estacionalidade de produção forrageira é um fenômeno praticamente inevitável - devido ao grande número de agentes causais da mesma (temperatura, precipitação e luz), e da interação destes entre si - com o qual os pecuaristas são obrigados a conviver, e que representa o principal motivo da baixa produtividade da atividade pecuária. Dentre as alternativas de amenização dos efeitos sazonais de produção de forragem, o diferimento de pastagens é a técnica mais simples e menos dispendiosa disponível ao produtor. Aspectos produtivos como espécies forrageiras mais apropriadas, épocas de vedação e utilização da pastagem, massa e valor nutritivo da pastagem no momento da sua utilização são encontrados com relativa facilidade em trabalhos de pesquisa envolvendo diferimento de pastagens. Por outro lado, estudos envolvendo perdas de 
forragem, e valor nutritivo tanto da planta ofertada quanto da dieta selecionada pelo animal no decorrer do período de pastejo, além do uso de fertilizantes, em especial o N, no momento de vedação da pastagem são escassos ou inexistentes.

Nesse contexto, fica estabelecida a necessidade de mais esforços para aprimorar o conhecimento dos efeitos de das adubações nitrogenadas no momento da vedação do pasto, em especial aqueles relativos ao desenvolvimento de ferramentas que diminuam as perdas de $\mathrm{N}_{-} \mathrm{NH}_{3}$ por volatilização, além de maior monitoramento dos parâmetros produtivos e nutricionais da forragem diferida sob pastejo. Com esse pensamento, o trabalho apresentado a seguir foi desenvolvido. 


\section{MATERIAL E MÉTODOS}

\subsection{Localização e Clima da área experimental}

O experimento foi conduzido no Centro de Pesquisa Pecuária do Sudeste - EMBRAPA (Fazenda Canchim), município de São Carlos-SP, localizado entre entre as latitudes $21^{\circ} 55^{\prime}$ e $22^{\circ} 00^{\prime}$ Sul e longitudes $47^{\circ} 48^{\prime}$ e $47^{\circ} 52^{\prime}$ Oeste, e na cota altimétrica média de $800 \mathrm{~m}$, em área experimental de aproximadamente 0,75 ha estabelecida com $B$. brizantha $\mathrm{cv}$. Marandu. O solo no local foi classificado como Latossolo Vermelho Escuro distrófico com as características químicas apresentadas na Tabela 6.

Tabela 6. Características químicas do solo da área experimental antes da instalação do experimento

\begin{tabular}{|c|c|c|c|c|c|c|c|c|c|c|c|}
\hline $\begin{array}{l}\text { PROFUNDIDADE } \\
\text { (cm) }\end{array}$ & $\begin{array}{c}\mathrm{pH} \\
\mathrm{CaCl}_{2}\end{array}$ & $\begin{array}{l}\text { M.O. } \\
\text { g.dm }\end{array}$ & $\begin{array}{c}\mathbf{P} \\
\text { resina } \\
\mathrm{mg} \cdot \mathrm{dm}^{3}\end{array}$ & $\mathrm{~K}$ & $\mathrm{Ca}$ & $\begin{array}{l}\mathrm{Mg} \\
---\mathrm{mr}\end{array}$ & $\begin{array}{l}\mathrm{H}+\mathrm{Al} \\
\mathrm{mol}_{\mathrm{c}} \cdot \mathrm{d}\end{array}$ & & S.B. CTC & $\begin{array}{c}\text { Sat. } \\
\text { Bases } \\
\text { V\% }\end{array}$ & $\begin{array}{c}\mathrm{S} \\
\mathrm{SO}_{4}\end{array}$ \\
\hline $0-20$ & 4,3 & 37,0 & 2,0 & 0,6 & 15,0 & 5,0 & 61,0 & 4,0 & $21,0 \quad 82,0$ & 26,0 & 24,0 \\
\hline $20-40$ & 4,3 & 31,0 & 2,0 & 0,5 & 8,0 & 3,0 & 58,0 & 4,0 & $12,082,0$ & 15,0 & 21,0 \\
\hline
\end{tabular}

O clima é "tropical de altitude", que, segundo a classificação de Koeppen, é o Cwa, quente com inverno seco, no qual a temperatura média do mês mais frio é inferior a $18^{\circ} \mathrm{C}$ e a do mês mais quente ultrapassa $22^{\circ} \mathrm{C}$. O total das chuvas do mês mais seco não atinge $30 \mathrm{~mm}$, e o do mês mais chuvoso alcança 
valores dez ou mais vezes superiores aos do mês mais seco. Os dados de precipitação e temperatura históricos e durante o período experimental podem ser observados nas Figuras 7 e 8.

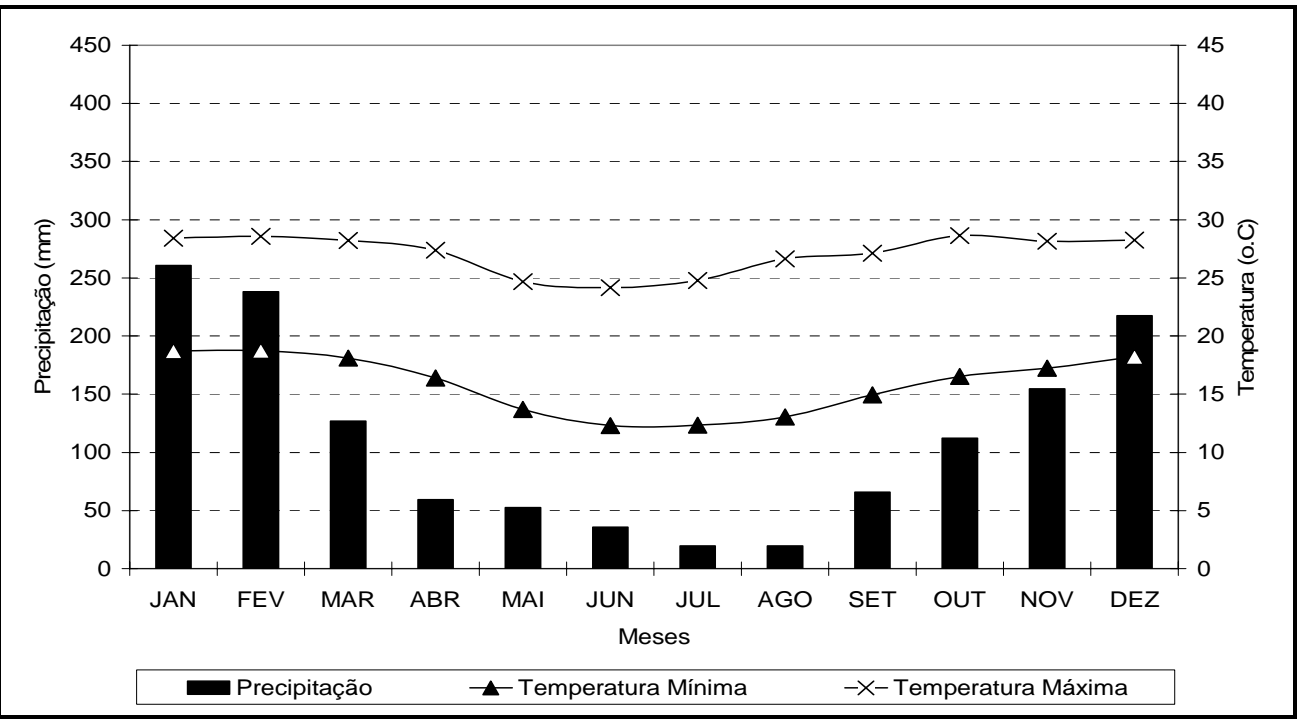

Figura 7 - Precipitação e temperatura máxima e mínima mensal na fazenda Canchim, EMBRAPA CPPSE (média do período de 1992 a 2003)

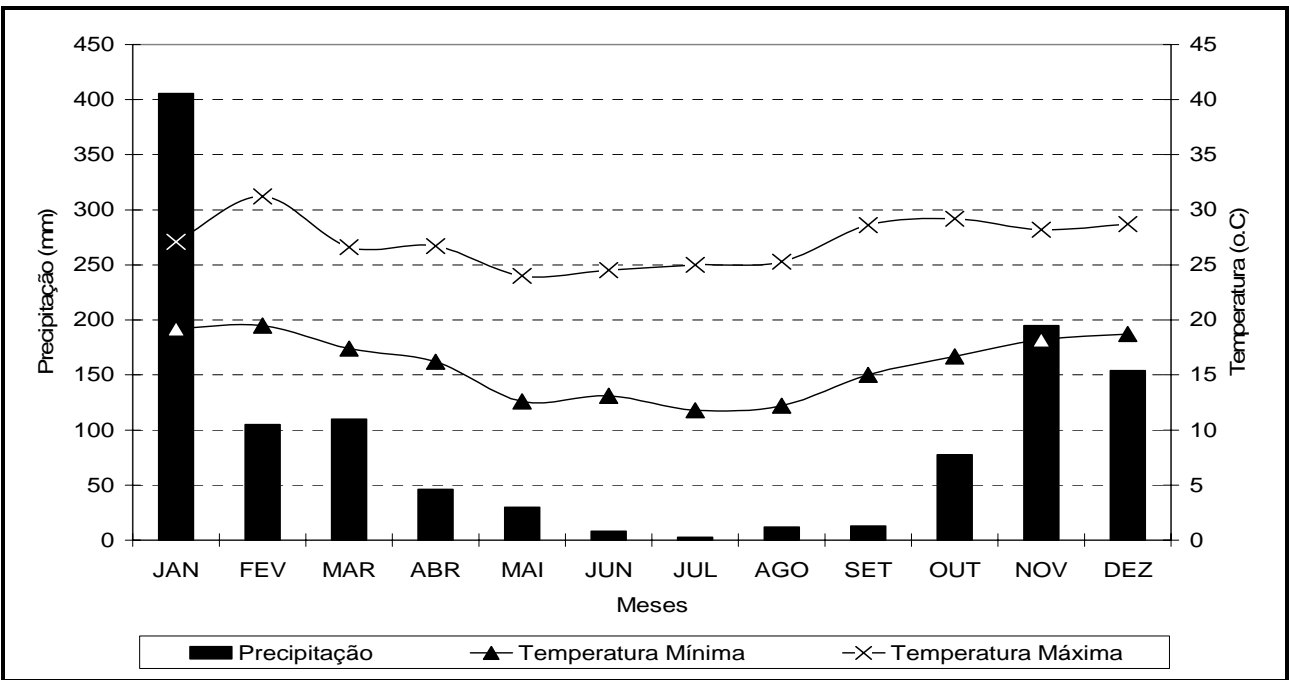

Figura 8 - Precipitação e temperatura máxima e mínima mensal na fazenda Canchim, EMBRAPA CPPSE durante o ano experimental (2003) 


\subsection{Delineamento experimental e tratamentos}

O delineamento experimental foi em blocos completos ao acaso com seis tratamentos (fontes de $\mathrm{N}$ no momento da vedação da pastagem) e quatro repetições, com medidas repetidas no tempo. O experimento foi dividido em três fases: período vedado ou de crescimento da planta, período de utilização ou pastejo, e período de rebrotação, no início das "águas" subseqüente. Os tratamentos estão descritos na Tabela 7 , sendo a dose de $\mathrm{N}$ utilizada de 50 $\mathrm{kg} \cdot \mathrm{ha}^{-1}$, aplicado a lanço, em todos os casos, com exceção da testemunha, que não recebeu esse nutriente.

Tabela 7. Adubações realizadas nas parcelas em março de 2003

\begin{tabular}{lcccc}
\hline \multirow{2}{*}{ Tratamento } & \multirow{2}{*}{$\begin{array}{c}\text { Fertilizantes utilizados no momento } \\
\text { de vedação }\end{array}$} & \multicolumn{4}{c}{ Adubação de nivelamento } \\
& & $\mathrm{P}_{2} \mathrm{O}_{5}$ & $\mathrm{~K}_{2} \mathrm{O}$ & $\mathrm{S}$ \\
\hline 1 (Test.) & - & 90 & 66 & 60 \\
$2(\mathrm{U})$ & Uréia (U) & 90 & 66 & 60 \\
$3(\mathrm{SA})$ & Sulfato de Amônio (SA) & 90 & 66 & - \\
$4(\mathrm{U}+\mathrm{SA})$ & $50 \%$ U e 50\% SA & & \\
$5(\mathrm{U}+\mathrm{SPS})$ & $50 \%$ U e 50\% Superfosfato Simples & \\
$6(\mathrm{U}+\mathrm{KCl})$ & $50 \%$ U e 50\% Cloreto de Potássio & 74 & 66 & 50 \\
\end{tabular}

${ }^{1}$ Mistura na proporção 1:1 baseada no fertilizante, e não no nutriente

Nos tratamentos onde foi feita a associação de fertilizantes, tomou-se por base a quantidade de fertilizante aplicada, e não a quantidade de nutriente, isto é, a mistura $U+S A$, por exemplo, continha $50 \%$ de $U$ e $50 \%$ de SA. O mesmo ocorreu para o $\mathrm{KCl}$ e o SPS.

Os níveis de $\mathrm{P}, \mathrm{K}$ e $\mathrm{S}$ no solo foram consideradas não limitantes ao crescimento das plantas devido ao uso das adubações de nivelamento 
apresentadas na Tabela 7. Essa adubação foi efetuada uma semana antes da instalação do experimento.

\subsection{Instalação e condução do experimento}

A área experimental foi dividida em 24 parcelas quadradas de $15 \mathrm{~m}$ de lado, dispostas em quatro fileiras de seis parcelas. Cada fileira foi considerada um bloco, sendo que entre os blocos centrais foi deixado um corredor de $5 \mathrm{~m}$ de largura.

Cada parcela foi separada individualmente por dois fios eletrificados, permitindo que cada uma fosse pastejada individualmente durante o período de utilização.

Entre 10 e 14 de março de 2003 a área foi pastejada procurando-se atingir um resíduo pós-pastejo entre 2500 e $3000 \mathrm{~kg} \mathrm{MS}$.ha-1. Após a retirada dos animais foi realizada a adubação de nivelamento em 15 de março e, na semana seguinte (22 de março) a massa de forragem (MF) remanescente foi quantificada (Resíduo 1, R1) e instalados os tratamentos.

Após essa data a área permaneceu em crescimento livre até o dia 5 de julho, momento em que foi quantificada a MF final (Produção, Prod), totalizando 104 dias de vedação. Durante esse período foram realizadas sete avaliações intermediárias da MF (Produções Intermediárias, PI) nos dias 06 de abril, 17 de abril, 01 de maio, 17 de maio, 31 de maio, 14 de junho e 29 de junho, ou seja, aos $14,25,39,55,69,83$ e 98 dias de crescimento da planta, respectivamente.

A partir do dia 14 de julho as parcelas foram pastejadas semanalmente por 16 bezerras da raça Canchim (Bos indicus L.) com peso médio de $220 \mathrm{~kg}$. Cada parcela recebia 2 novilhas, sendo a duração de cada pastejo de cerca de $20 \mathrm{~h}$. As novilhas eram presas nas parcelas às $14 \mathrm{~h}$ e soltas em uma área de apoio às $10 \mathrm{~h}$ da manhã seguinte, onde permaneciam até a entrada na parcela seguinte. Dessa forma, levavam três dias para que as 24 parcelas fossem 
pastejadas. Nos quatro dias restantes da semana, os animais permaneciam na área de apoio.

Não havia fornecimento de água aos animais dentro das parcelas, por isso a necessidade de mantê-los pelo menos 4 horas com acesso a um bebedouro. Apesar dessa restrição, aparentemente o pastejo não foi severamente afetado, uma vez que durante observações freqüentes, em vários períodos do dia, não foram constatadas mudanças visuais nos hábitos das bezerras quando comparadas aos animais com livre acesso à água em pastos vizinhos. Os animais foram utilizados como ferramenta de desfolha, não sendo avaliados consumo e desempenho.

Durante período de pastejo, que durou 9 semanas, foram avaliadas a cada duas semanas a MF (Resíduo Intermediário, RI), as perdas decorrentes do pastejo, além de serem coletadas amostras de pastejo simulado (PS). Na $9^{\circ}$ semana, com exceção do PS, essas avaliações também foram realizadas, no dia 20 de setembro, e consideradas o resíduo final desse período (Resíduo 2, $\mathrm{R} 2)$.

O término do período de pastejo ocorreu quando se observou uma proporção de colmos na forragem disponível de quase 100\% (Figura 9).
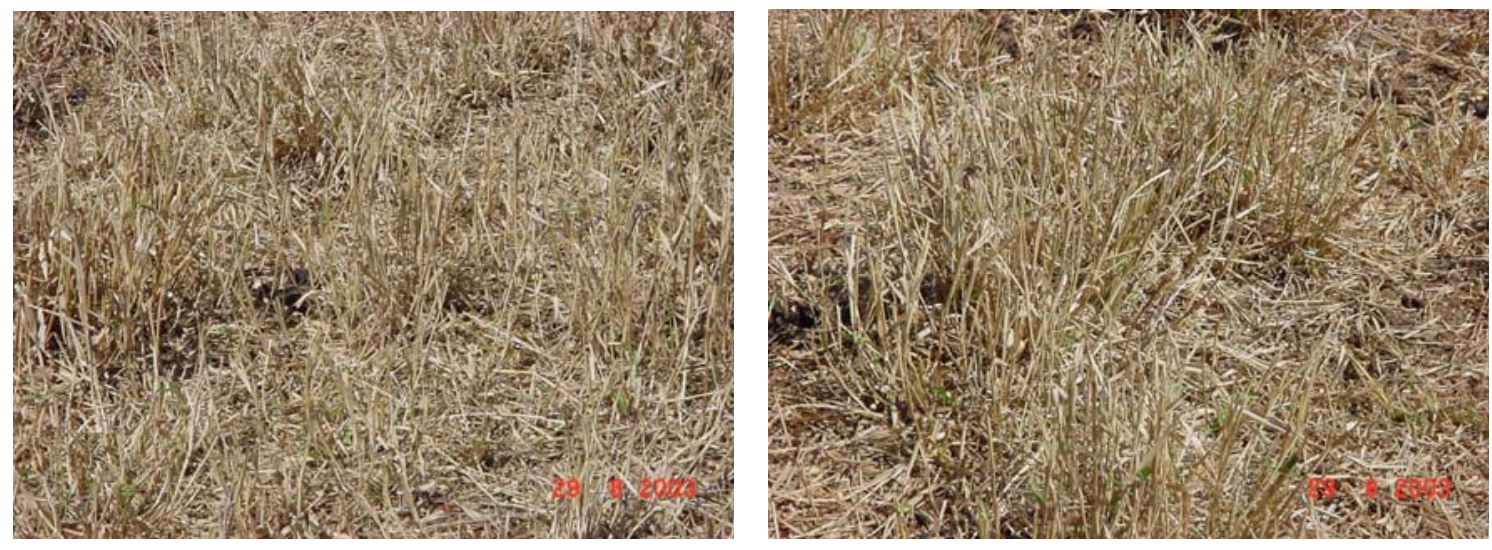

Figura 9 - Caracterização visual do resíduo de forragem nas parcelas após 9 semanas de pastejo (Resíduo 2) 
A avaliação da rebrotação do capim iniciou-se em 25 de outubro, após 0 acúmulo de $80 \mathrm{~mm}$ de chuvas, monitoradas a partir do Resíduo 2. Um segunda avaliação da rebrota foi realizada no dia 07 de novembro, sendo também o momento em foi encerrada a coleta de dados no campo.

\subsection{Respostas medidas}

\subsubsection{Determinações no campo}

\subsubsection{Massa de forragem (Prod, PI, R1, R2, RI e Rebrota)}

A quantificação dessa resposta ocorreu durante os três períodos do experimento, nas datas já descritas, utilizando-se um quadrado de $0,5 \mathrm{~m}$ de lado.

Com o auxílio de uma linha transecta disposta transversalmente na parcela, foram alocados três pontos de amostragem em cada data de coleta, sendo a forragem presente dentro de cada quadrado cortada rente ao solo. $\mathrm{O}$ local dos quadrados em uma determinada data era sempre $1 \mathrm{~m}$ à frente do local da coleta anterior e disposto no lado oposto da linha (Figura 10).

Foi utilizada uma transversal no período de crescimento (T1) e outra no período de pastejo (T2), sendo que no período de rebrotação as coletas voltaram a ser feitas na transversal inicial (Figura 10).

Após a coleta, as amostras eram pesadas e uma subamostra era retirada, pesada e levada à estufa $a 5^{\circ} \mathrm{C}$ por $72 \mathrm{~h}$, para determinação do seu peso seco e posterior cálculo do teor de massa seca (MS) da forragem. O cálculo da

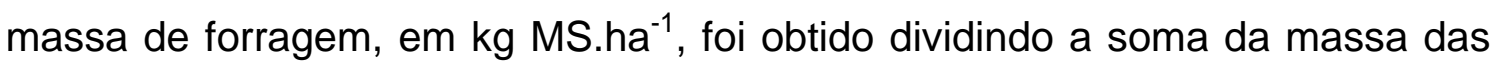
amostras dos três quadrados pela soma de suas áreas $\left(0,75 \mathrm{~m}^{2}\right)$, multiplicando 
o valor obtido por 10.000 (área de 1 ha) e pelo teor de MS. As análises foram moídas em moinho tipo Wiley com peneira de abertura de $1 \mathrm{~mm}$ e levadas ao laboratório de Bromatologia do Departamento de Zootecnia (ESALQ-USP) para proceder as determinações químico-bromatológicas.
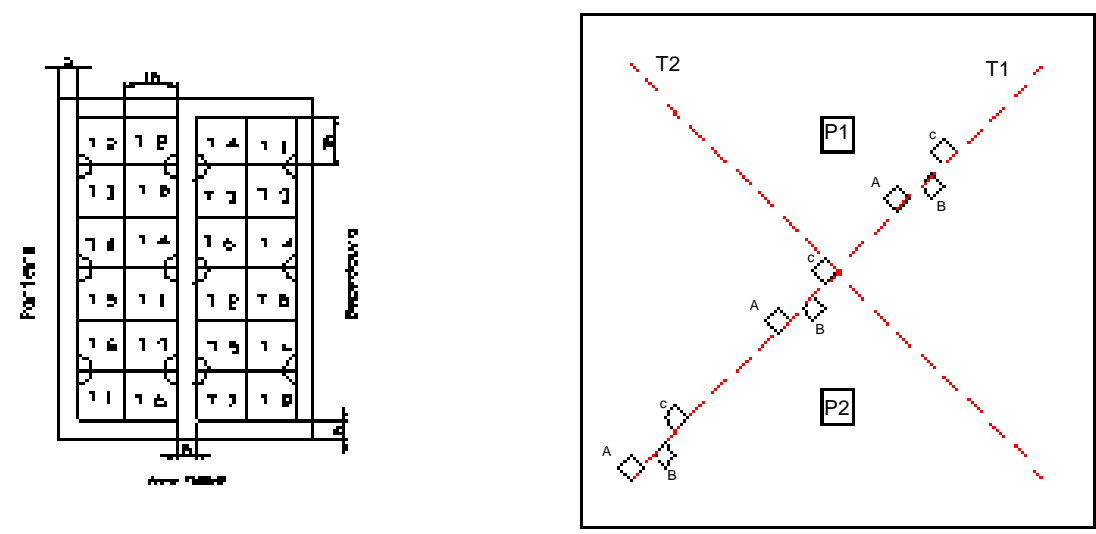

A, B, C Seqüência das sucessivas coletas de MF ao longo dos momentos de avaliação, sempre 1 $m$ a frente da coleta anterior (i.e. A em relação a $B$ e $B$ em relação a $C$ )

$\mathrm{T} 1, \mathrm{~T} 2$ Linhas transectas 1 e 2

P1, P2 Local das coletas de perdas.

Figura 10 - Croqui da área experimental com destaque para os métodos de avaliação das MF e Perdas

Uma segunda subamostra retirada das amostras de MF foi utilizada para determinação da composição morfológica (proporções de haste, folha e material morto), conforme metodologia utilizada por Tosi (1999). A estimativa da produção de massa seca verde (MSV) e de lâmina foliar verde (LFV) foi determinada multiplicando-se a MF pela proporção desses componentes. Também foi determinada a relação folha haste $(\mathrm{F}: \mathrm{H})$ com o auxílio desses componentes. 


\subsubsection{Modelagem das respostas produtivas através de índices climáticos}

A determinação do acúmulo de forragem em graus-dia (GD) e unidades fototérmicas (UF) ocorreu somente durante o período de crescimento, utilizando-se os dados de massa de forragem nas diferentes épocas de coleta e os dados de GD e UF acumulados no período. Para o cálculo de GD e UF acumuladas em cada data de coleta, foram utilizadas as equações (8), (9) e (10), citadas por Villa Nova et al. (1999).

$$
\begin{aligned}
& \mathrm{GD}=\mathrm{N}(\overline{\mathrm{T}}-\mathrm{TBi}), \text { quando } \mathrm{TBi}<\overline{\mathrm{T}} \min \\
& \mathrm{GD}=\mathrm{N} \frac{(\overline{\mathrm{T}} \max -\mathrm{TBi})^{2}}{2(\overline{\mathrm{T}} \max -\overline{\mathrm{T}} \min )} \text {, quando } \mathrm{TBi}>\overline{\mathrm{T}} \min \\
& U F=\frac{\left(\frac{N}{2} \overline{G D}\right)^{\frac{N f}{N i}+1}}{\frac{N f}{N i}+1}
\end{aligned}
$$

\section{Em que:}

$\overline{\mathrm{GD}}=$ número de graus-dia médio do período de $\mathrm{N}$ dias;

$\mathrm{N}=$ Número de dias no período;

$\overline{\mathrm{T}}=$ média das temperaturas médias do período;

$\mathrm{TBi}=$ Temperatura base inferior para o determinado cultivar, neste caso considerada $15^{\circ} \mathrm{C}$;

$\overline{\mathrm{T}} \max =$ média das temperaturas máximas do período;

$\overline{\mathrm{T}}$ min = média das temperaturas mínimas do período;

$\mathrm{Nf}=$ Valor do fotoperíodo (horas e décimos) no final do período de crescimento;

$\mathrm{Ni}=$ Valor do fotoperíodo (horas e décimos) no início do período de crescimento. 


\subsubsection{Densidade volumétrica da forragem}

A densidade volumétrica da forragem ( $\mathrm{kg} \mathrm{MS} \cdot \mathrm{ha}^{-1} . \mathrm{cm}$ de altura ${ }^{-1}$ ) foi estimada somente no período de pastejo, dividindo-se a massa de forragem em uma determinada data pela altura média da pastagem naquele momento. A determinação da altura do dossel foi feita seguindo método utilizado por Penati (2002), sendo a média composta de nove pontos distintos da parcela. Esse mesmo método foi empregado na determinação da densidade volumétrica da forragem verde (kg MSV.ha ${ }^{-1} . \mathrm{cm}$ de altura ${ }^{-1}$ ).

\subsubsection{Perdas pós-pastejo}

Foram marcados dois quadrados com $1 \mathrm{~m}$ de lado para determinar as perdas de forragem em cada parcela. Essas áreas foram marcadas com quatro estacas na porção central da parcela com o auxílio de uma moldura, de modo que não houvesse sobreposição com as linhas transversais, e por esse mesmo motivo foi utilizado o mesmo local de coleta para todas as avaliações de perdas (Figura 10).

Antes do primeiro pastejo esses pontos foram limpos, sendo retirado todo o material presente entre as touceiras e a cada duas semanas foi coletado todo o material depositado dentro da área demarcada, ou seja, as avaliações das perdas eram coincidentes com as determinações de MF.

Após a coleta, as amostras eram pesadas e uma subamostra era retirada, pesada e levada à estufa a $65^{\circ} \mathrm{C}$ por $72 \mathrm{~h}$, para determinação do seu peso seco e posterior cálculo do teor de MS do material. O cálculo da quantidade de perdas, em kg MS.ha-1 ${ }^{-1}$, foi obtido dividindo a soma da massa das amostras dos dois quadrados pela soma de suas áreas $\left(2 \mathrm{~m}^{2}\right)$, multiplicando o valor obtido por 10.000 (área de 1 ha) e pelo teor de MS. Com esses dados e com a MF 
avaliada na coleta anterior à mesma, foi calculada a porcentagem de forragem perdida durante os pastejos.

\subsubsection{Simulação de Pastejo}

Para a realização dos PS, foram utilizadas duas gaiolas de exclusão por parcela, de dimensões $0,70 \mathrm{~m}$ de lado e $1,0 \mathrm{~m}$ de altura. A função destas gaiolas foi a de manter a forragem no seu interior fora do alcance dos animais em pastejo. Após a saída dos animais da parcela, foi simulado o pastejo na área da gaiola de exclusão, de modo a deixar a planta forrageira com o mesmo aspecto visual daquela pastejada. A Figura 11 ilustra a forragem dentro e fora da gaiola nos pastejos iniciais.
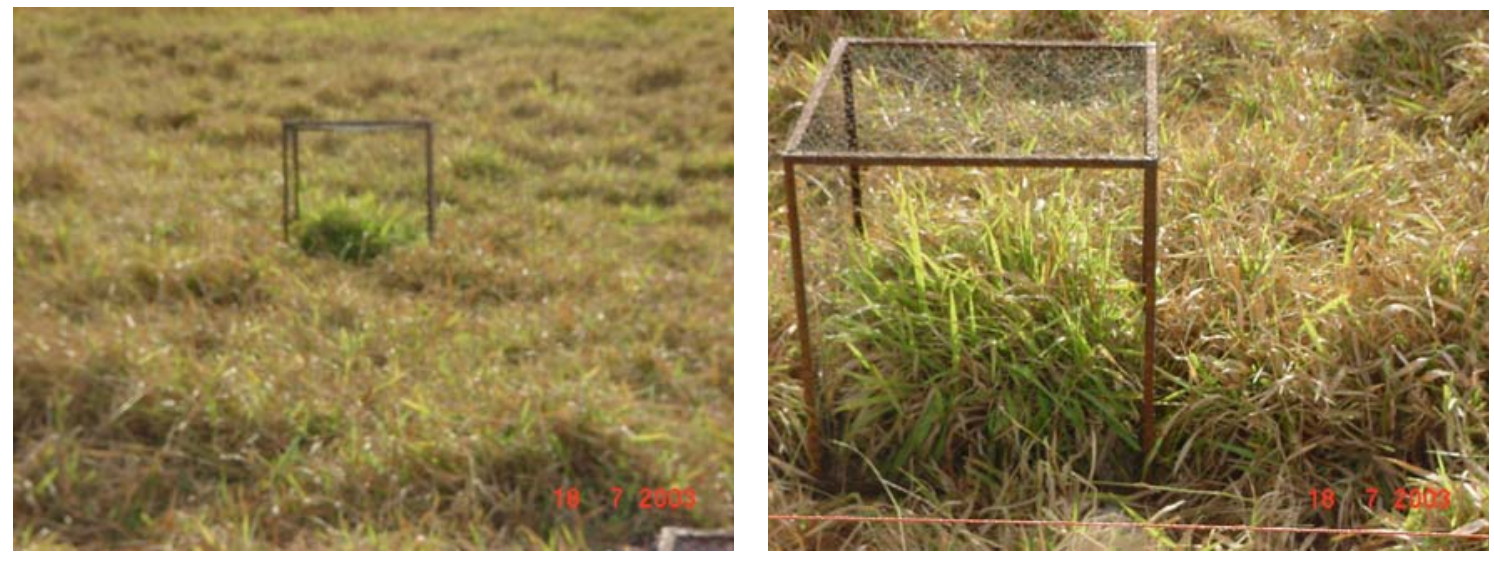

Figura 11 - Imagem da parcela com material a ser coletado dentro das gaiolas após os primeiros pastejos

A localização das gaiolas não seguia uma linha transecta, buscando-se sempre locais representativos e que ainda não tivessem sido utilizados nessa função.

Após a coleta, as amostras eram pesadas e levadas à estufa a $65^{\circ} \mathrm{C}$ por 72 h, para determinação do seu peso seco. Após esse processo, elas foram 
moídas em moinho tipo Wiley com peneira de abertura de $1 \mathrm{~mm}$ e levadas ao laboratório de Bromatologia do Departamento de Zootecnia (ESALQ-USP) para proceder as determinações químico-bromatológicas.

\subsubsection{Recuperação aparente do nitrogênio aplicado}

A partir do teor de nitrogênio $(\% \mathrm{~N})$ das subamostras usadas para determinação do teor de MS da MF, e da produção de forragem, foi calculado o acúmulo de $\mathrm{N}\left(\mathrm{kg} \mathrm{N} \cdot \mathrm{ha}^{-1}\right)$ e, a partir deste, a recuperação aparente do nitrogênio aplicado (Rap), através da fórmula (11)

$$
\begin{aligned}
& \text { Rap } \left.=\underline{\left(\mathrm{kg} \mathrm{N} \cdot \mathrm{ha}^{-1}\right.} \underline{\underline{\text { tratamento }})-\left(\mathrm{kg} \mathrm{N} \cdot \mathrm{ha}^{-1}\right.} \underline{\underline{\text { testemunha }}}\right) \\
& \text { Dose de } \mathrm{N} \text { aplicada }
\end{aligned}
$$

\subsubsection{Determinações químico-bromatológicas}

As determinações químico-bromatológicas executadas foram: cinzas, nitrogênio total $(\% N)$; proteína bruta $(P B, \% N \times 6,25)$; extrato etéreo (EE); fibra insolúvel em detergente neutro (FDN); fibra insolúvel em detergente ácido (FDA); Lignina a $72 \%$ de $\mathrm{H}_{2} \mathrm{SO}_{4}$ (Lig); nitrogênio retido à FDN (NFDN); nitrogênio retido à FDA (NFDA) e digestibilidade verdadeira in vitro da MS (DIVMS).

Primeiramente as amostras foram submetidas a leituras de infravermelho proximal pelo aparelho NIRS (Near Infrared Reflectance Spectometer) para geração de suas curvas espectrais. $O$ aparelho utilizado foi um monocromato NIRS 5000 (NIRSystems, Silver Spring, MD, USA). Após a leitura de todas as amostras, o "software" do NIRS determinou quais amostras eram redundantes, isto é, as que possuíam curvas espectrais semelhantes, e quais deveriam ser 
analisadas pela metodologia convencional, servindo posteriormente de banco de dados para a estimativa das amostras não analisadas.

Cerca de $40 \%$ do total das amostras foram destinadas à análise convencional, onde se procedeu primeiramente a determinação da matéria seca e matéria mineral, conduzidas em duplicata, conforme metodologia descrita por Silva, D. (2002). As mesmas amostras foram analisadas para determinação dos teores de PB, NFDN e NFDA.

A determinação do $\mathrm{N}$ total da amostra foi obtida através da combustão da mesma, segundo o método de Dumas, utilizando-se o auto-analisador de nitrogênio LECO FP-528 (Leco Corporation, St. Joseph, MI, USA; WILES et al., 1998).

As determinações de NFDN e NFDA procederam-se da seguinte forma: analisou-se primeiro as frações FDN e FDA, segundo metodologia de Van Soest et al. (1991), utilizando-se o equipamento "Ankon 200 Fiber Analyser" (Ankon Technology Corporation) e posteriormente foi determinado o $\mathrm{N}$ total das mesmas em Macro Kjeldhal. O $\mathrm{N}$ total da FDN e FDA dividido pelo $\mathrm{N}$ total da amostra original resultou nas frações NFDN e NFDA.

As demais determinações (EE, FDN, FDA, Lig e DIVMS) foram obtidas através de estimativas do sistema NIRS utilizando equações já existentes em seu banco de dados.

A partir desses dados foi calculado o NDT (nutrientes digestíveis totais) das amostras de pastejo simulado durante o período de utilização. A metodologia utilizada nessa estimativa foi proposta por Weiss (1992), com as modificações sugeridas pelo NRC (2001), representadas pelas equações que se seguem:

$$
\begin{aligned}
& N D T=\operatorname{tdCNF}+\operatorname{tdPB}+(\operatorname{tdAG} \times 2,25)+\operatorname{tdFDN}-7 \\
& \operatorname{tdCNF}=0,98\left\{100-\left[(\text { FDN }-\mathrm{PBFDN})^{\star}+\mathrm{PB}+\mathrm{EE}+\mathrm{Cinzas}\right]\right\} \times \mathrm{FAP}
\end{aligned}
$$


$\operatorname{tdPB}=\mathrm{PB}^{[-1,2 \times(\mathrm{PBFDA} / \mathrm{PB})]}$

$\operatorname{td} A G=A G=E E-1$. Se $E E<1, A G=0$

$\operatorname{tdFDN}=0,75 \times\left[(\text { FDN }- \text { PBFDN })^{*}-\right.$ Lig $\left.] \times\left\{1-[\text { Lig/(FDN-PBFDN })^{*}\right]^{0,667}\right\}$

* se a FDN for determinada adicionando sulfito de sódio, não subtrair a PBFDN

Em que:

tdCNF = Carboidratos não fibrosos verdadeiramente digestíveis;

$\mathrm{tdPB}=$ Proteína Bruta verdadeiramente digestível;

tdAG = Ácidos graxos verdadeiramente digestíveis;

tdFDN = FDN verdadeiramente digestível;

PBFDN = Proteína bruta ligada a FDN;

FAP = Fator de ajuste de processamento, neste caso igual a 1;

PBFDA = Proteína bruta ligada a FDA.

Lig = Lignina

\subsection{Análise estatística dos dados}

Os dados foram analisados usando o procedimento de análise de modelos mistos (Proc Mixed) do programa estatístico SAS (SAS, 1995). Nas análises de variância incluiu-se no modelo tratamento e período como efeito fixo, e a interação bloco tratamento como efeito aleatório. Dado que as observações foram mensuradas entre março e novembro de 2003, para modelar as covariâncias existentes entre as diferentes medidas, considerou-se como medida repetida as observações tomadas em diferentes períodos dentro do mesmo tratamento e bloco. Nos modelos de covariância considerou um modelo semelhante ao anterior. Entretanto, período foi considerado variável continua. 
Nesta análise (de covariância) foi adotada a estratégia descrita por Littell et al. (1996), capítulo 5, para escolha do melhor modelo para ajuste dos dados. 


\section{RESULTADOS E DISCUSSÃO}

\subsection{Período de Crescimento}

\subsubsection{Acúmulo de forragem}

Houve efeito de tratamento e de momento de coleta nas análises de massa de forragem, não havendo no entanto efeito de interação entre os dois. O tratamento $100 \%$ SA apresentou maior massa média de forragem total, de forragem verde e de lâminas de folhas verdes, não diferindo dos tratamentos $U$ e U+SA (Tabelas 8, 9 e 10). A superioridade do sulfato de amônio justifica-se por essa fonte de nitrogênio ser menos propensa às perdas de $\mathrm{N}$ por volatilização (Martha Júnior, 1999). No entanto, o valor de R1 de $4187 \mathrm{~kg}$ $\mathrm{MS}^{-h^{-1}}$ para o SA (Tabela 8) pode ter beneficiado esse tratamento, uma vez que seu crescimento foi iniciado com uma massa de forragem (MF) remanescente numericamente superior aos demais tratamentos.

As associações de fertilizantes, principalmente os tratamentos $\mathrm{U}+\mathrm{KCl}$ e U+SPS, não apresentaram resposta positiva decorrente dos efeitos dessas misturas, sendo as MF médias semelhantes a da testemunha.

Além disso, o tratamento U+SA, mesmo contendo $30 \%$ do nitrogênio na forma amoniacal, não foi superior ao tratamento $100 \%$ U. Uma das razões que podem explicar o baixo desempenho dessas associações foi a provável 
segregação dos grânulos dos diferentes fertilizantes durante o momento da aplicação, uma vez que os fertilizantes foram associados através da mistura de grânulos.

Tabela 8. Massa total de forragem seca durante o período de crescimento nos seis tratamentos testados

\begin{tabular}{ccccccc}
\hline $\mathrm{Dia}^{2}$ & Test. & $\mathrm{U}$ & $\mathrm{SA}$ & $\mathrm{U}+\mathrm{SA}$ & $\mathrm{U}+\mathrm{SPS}$ & $\mathrm{U}+\mathrm{KCl}$ \\
\hline $\mathrm{R}^{3}$ & 2777,0 & 2638,6 & 4187,3 & 2339,3 & 2756,2 & 3058,0 \\
25 & 4340,2 & 6331,8 & 7063,9 & 6401,8 & 4983,1 & 4188,5 \\
55 & 5108,8 & 6280,6 & 8684,8 & 7335,3 & 4880,8 & 5831,7 \\
83 & 6330,9 & 8724,3 & 7645,4 & 6382,5 & 5648,3 & 6733,8 \\
Prod $^{4}$ & 4929,8 & 5098,4 & 7491,5 & 7019,3 & 5057,2 & 7018,1 \\
Média $^{1}$ & $4878,4^{\mathrm{b}}$ & $5859,9^{\mathrm{ab}}$ & $6608,8^{\mathrm{a}}$ & $5558,4^{\mathrm{ab}}$ & $4896,6^{\mathrm{b}}$ & $5379,1^{\mathrm{b}}$ \\
\hline
\end{tabular}

${ }^{1}$ Médias seguidas por mesma letra, minúscula na linha, não diferem entre si pelo teste de Tukey $(p>0,05)$

${ }^{2}$ Período compreendido entre os dias 22 de março de 2003 e 05 de julho de 2003

${ }^{3}$ Valores relativos ao resíduo após o pastejo de uniformização da área experimental. Dia 0

${ }^{4}$ Valores relativos à produção final de forragem aos 104 dias de vedação

Luz (2000) estudando a aplicação a lanço de U+KCl na forma de mistura de grânulos (22:00:22) em áreas de soqueira de cana de açúcar, verificou que os grânulos de $U$ foram depositados mais próximos à distribuidora de fertilizantes, enquanto que os de $\mathrm{KCl}$, maiores e mais densos, alcançaram maiores distâncias. Esse autor menciona que a distribuição do fertilizante se apresentou na proporção correta somente no intervalo de 3 a $4 \mathrm{~m}$, quando o espaçamento de aplicação foi de 6,55 m. Regiões mais próximas do aplicador apresentaram teores de $\mathrm{N}$ superiores e nas regiões periféricas esses teores estavam abaixo do planejado. O mesmo ocorreu para o $\mathrm{KCl}$, só que em ordem inversa.

Como a adubação no presente experimento foi realizada a lanço, pode-se inferir que os diferentes fertilizantes tenham sido depositados em regiões 
distintas da parcela. Nesse sentido, os cloretos e sulfatos estariam dissociados dos grânulos de uréia, e assim não interagiriam com a mesma. Trabalhos futuros devem considerar o uso de fertilizantes na forma de mistura no grânulo para definir os reais efeitos negativos da segregação de fertilizantes.

Outro complicante da segregação de fertilizantes pode ter ocorrido no tratamento U+SA. A desuniformidade na distribuição dos componentes dessa mistura colocaria menos nitrogênio nas áreas onde o sulfato segregasse da uréia, elevando-se o coeficiente de variação das amostras coletadas, o que provavelmente explicaria as MF semelhantes às do tratamento $U$.

A segregação dos fertilizantes tem efeitos ainda mais acentuados nos tratamentos U+SPS e U+KCl, uma vez que em determinadas regiões das parcelas não houve fornecimento de $\mathrm{N}$, o que poderia explicar a semelhança dos resultados com os da testemunha.

Resultados de superioridade do uso do sulfato de amônio em relação à uréia e associações de fertilizantes no momento do diferimento também foram encontrados por Paulino et al. (1995), estudando o diferimento de $B$. decumbens. O uso de SA nesse trabalho foi significativamente superior a todos os demais tratamentos, atingido um pico de produção de $6900 \mathrm{~kg} \mathrm{MS} \cdot \mathrm{ha}^{-1}$ aos 122 dias de crescimento, valor semelhante à produção média do SA no presente trabalho. Além disso, os tratamentos 100\% uréia e uréia associada ao sulfato de magnésio não diferiram entre si naquele trabalho, atingindo o máximo de produção (5000 kg MS.ha-1) aos 173 dias de crescimento. Esse valor foi inferior ao determinado para $U$ e U+SA, porém semelhantes aos valores médios de U+SPS e U+KCl. A testemunha produziu $3200 \mathrm{~kg} \mathrm{MS}$.ha $^{-1}$ aos 173 dias de crescimento, sendo esse valor bem inferior ao apresentado na Tabela 8.

Outras pesquisas sobre diferimento de pastagens como as de Pizarro et al. (1996), Leite et al. (1998) e Gomes (2003) apresentaram acúmulos de

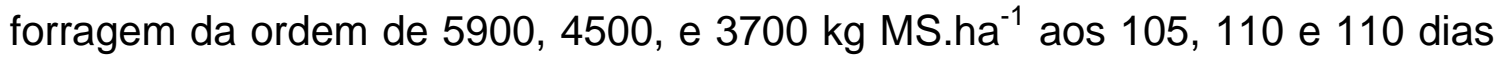
de crescimento, respectivamente. Essas produtividades, exceto para a de menor valor, se assemelham às observadas na Tabela 8. 0 trabalho de Pizarro 
et al. (1996) e Gomes (2003) não receberam adubação nitrogenada, porém os valores mais elevados de massa de forragem observados pelo primeiro autor são justificados pela vedação da pastagem em fevereiro e sua utilização em junho, enquanto que os baixos valores obtidos Gomes (2003) podem ser explicados pelo momento de vedação da pastagem, que ocorreu em março, associado com o regime hídrico da região, caracterizado pelo cessamento precoce das chuvas.

Paulino et al. (1995) encontraram eficiências agronômicas superiores quando utilizaram SA comparado à uréia em $B$. decumbens, sendo os valores

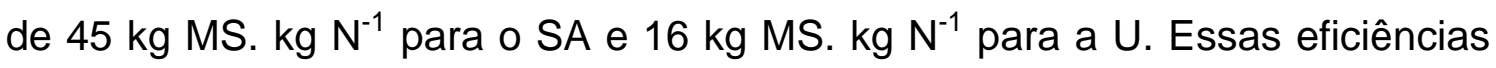
foram semelhantes às calculadas a partir dos valores médios da Tabela 8, que foram de 35 e $19 \mathrm{~kg} \mathrm{MS.kg} \mathrm{N}{ }^{-1}$ para o SA e U, respectivamente.

Por outro lado, as eficiências do SA aos 55 dias de crescimento e da $U$

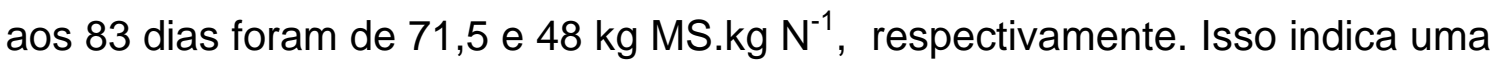
tendência de pico de produção de forragem nos tratamentos $U$ e SA nas datas avaliadas, com reduções subseqüentes no decorrer do período. Apesar dessas diferenças não terem sido significativas, elas apresentam um valor biológico considerável, uma vez que o diferencial de produção do tratamento $U$ entre os momentos 83 e Prod poderiam aumentar a taxa de lotação da pastagem em quase 1,3 UA durante 150 dias, considerando uma oferta de forragem de $4 \%$ do peso vivo do animal.

Os tratamentos que receberam $\mathrm{N}$, em especial SA, U e U+SA terminaram o período de crescimento com MF numericamente menores que as máximas obtidas, aos 55, 83 e 55 dias de vedação, respectivamente (Tabelas 8 e 9). As tendências de decréscimo na produção de forragem, tanto total quanto verde, sinalizam um manejo inadequado desses tratamentos, uma vez que a forragem produzida não foi aproveitada em seu potencial máximo. Adubações nitrogenadas de pastagens diferidas deveriam então ser empregadas em áreas destinadas à primeira metade das "secas", ou seja, o adubo nitrogenado serviria como ferramenta de manejo que permitiria maior crescimento de forragem 
destinada ao final do outono e início do inverno. No caso de pastagens destinadas ao final das "secas", uma alternativa poderia ser a diminuição da dose de nitrogênio utilizada, ou até eliminação da adubação, a tal ponto que o ritmo de crescimento da planta proporcionasse um IAF ótimo coincidente com o início da época de utilização.

Tabela 9. Massa de forragem verde durante o período de crescimento nos seis tratamentos testados

\begin{tabular}{ccccccc}
\hline Dia $^{2}$ & Test. & U & SA & U+SA & U+SPS & U+KCl \\
\hline R1 $^{3}$ & 1720,4 & 1482,7 & 2186,4 & 1345,6 & 1513,6 & 1933,9 \\
25 & 2199,5 & 3352,4 & 3960,0 & 3802,7 & 2815,1 & 2416,7 \\
55 & 2164,3 & 3206,9 & 5278,1 & 4226,2 & 2753,6 & 2738,2 \\
83 & 2502,1 & 5221,1 & 4816,5 & 3264,1 & 2467,8 & 3850,4 \\
Prod $^{4}$ & 2091,8 & 2410,2 & 4034,0 & 3730,7 & 2122,8 & 3422,8 \\
Média $^{1}$ & $2323,7^{c}$ & $3179,5^{\text {ab }}$ & $3804,2^{\text {a }}$ & $3116,4^{\text {ab }}$ & $2495,1^{\text {bc }}$ & $2923,7^{\text {bc }}$ \\
\hline
\end{tabular}

${ }^{1}$ Médias seguidas por mesma letra, minúscula na linha, não diferem entre si pelo teste de Tukey $(p>0,05)$

${ }_{2}^{2}$ Período compreendido entre os dias 22 de março de 2003 e 05 de julho de 2003

${ }^{3}$ Valores relativos ao resíduo após o pastejo de uniformização da área experimental. Dia 0

${ }^{4}$ Valores relativos à produção final de forragem aos 104 dias de vedação

Para a MSV, os valores apresentados (Tabela 9) são semelhantes, aos encontrados por Euclides et al. (1990), inferiores aos de Costa et al. (1993) e superiores aos de Gomes (2003), que produziram 3150; 4650 e 2100 kg MSV.ha' ${ }^{-1}$, respectivamente, ao redor de 110 dias de crescimento. Como observado para a produção de MS, os dados de Gomes (2003) foram prejudicados pela restrição hídrica, enquanto que os valores superiores do trabalho de Costa et al. (1993) são decorrentes das temperaturas mais elevadas, e regime de chuva mais abundante com distribuição mais uniforme durante a execução do trabalho. 
Houve efeito de tratamento, de momento de avaliação e de interação entre tratamento e data para o acúmulo de lâmina de folhas verdes (LFV) durante o período de crescimento. $O$ tratamento SA apresentou a maior massa média de lâminas de folhas verdes, não diferindo dos tratamentos U e U+SA.

Como determinado na MF total e na MF verde, os tratamentos $U$, SA e U+SA apresentaram maior massa numérica de LFV aos 83, 55 e 55 dias, respectivamente. No acúmulo LFV, no entanto, houve diferença significativa para o tratamento $U$ entre os 83 dias e a Prod, e no tratamento SA a tendência de decréscimo ficou mais aparente que nos demais parâmetros discutidos, uma vez que a massa de LFV aos 55 dias foi a única que diferiu daquela representada pelo R1.

Tabela 10. Massa de lâminas de folhas verdes durante o período de crescimento nos seis tratamentos testados

\begin{tabular}{|c|c|c|c|c|c|c|}
\hline $\mathrm{Dia}^{2}$ & Test. & $U$ & SA & $\mathrm{U}+\mathrm{SA}$ & U+SPS & $\mathrm{U}+\mathrm{KCl}$ \\
\hline & \multicolumn{6}{|c|}{------------------------------- kg LFV.ha' } \\
\hline $\mathrm{R} 1^{3}$ & $526,8^{A}$ & $411,8^{\mathrm{B}}$ & $751,1^{\mathrm{B}}$ & $546,2^{\mathrm{A}}$ & $547,2^{\mathrm{A}}$ & $675,3^{\mathrm{A}}$ \\
\hline 25 & $873,2^{\mathrm{A}}$ & $1542,6^{\mathrm{B}}$ & $1918,7^{A B}$ & $1630,1^{\mathrm{A}}$ & $1265,5^{\mathrm{A}}$ & $971,5^{\mathrm{A}}$ \\
\hline 55 & $903,7^{\mathrm{A}}$ & $1360,9^{B}$ & $2212,0^{A}$ & $2104,1^{\mathrm{A}}$ & $1444,8^{A}$ & $1188,7^{\mathrm{A}}$ \\
\hline 83 & $1041,4^{\mathrm{A}}$ & $2938,8^{A}$ & $2119,5^{A B}$ & $1587,2^{A}$ & $1007,0^{\mathrm{A}}$ & $1796,7^{A}$ \\
\hline Prod $^{4}$ & $953,6^{A}$ & $1104,6^{\mathrm{B}}$ & $1716,8^{\mathrm{AB}}$ & $1666,1^{\mathrm{A}}$ & $1028,0^{A}$ & $1460,4^{\mathrm{A}}$ \\
\hline Média $^{1}$ & $910,4^{c}$ & $1436,5^{a b}$ & $1679,8^{\mathrm{a}}$ & $1394,8^{a b}$ & $1139,9^{b c}$ & $1213,8^{\mathrm{bc}}$ \\
\hline
\end{tabular}

${ }^{1}$ Valores seguidos por mesma letra, minúscula na linha e maiúscula na coluna, não diferem entre si pelo teste de Tukey $(p>0,05)$

${ }^{2}$ Período compreendido entre os dias 22 de março de 2003 e 05 de julho de 2003

${ }^{3}$ Valores relativos ao resíduo após o pastejo de uniformização da área experimental. Dia 0

${ }^{4}$ Valores relativos à produção final de forragem aos 104 dias de vedação

Além das maiores massas de LFV nos tratamentos que receberam $\mathrm{N}$, essa fração também foi mais representativa na MSV, uma vez que a MSV da testemunha era composta por 39\% de LFV (Tabelas 9 e 10) enquanto que nos demais tratamentos as LFV representavam entre $42 \%$ e $46 \%$ dessa fração. 
Por outro lado, apesar das diferenças de massa de LFV acumuladas entre os tratamentos, não houve efeito significativo de tratamento para a relação folha:haste, sendo essa crescente ao longo do período avaliado (Figura 12), tendendo a estabilizar ao redor do valor 0,90 a partir dos 55 dias do período de diferimento. Os dados apresentados são inferiores aos obtidos por Euclides et al. (1990) e Gomes (2003), que consistentemente determinaram relações acima de 1.

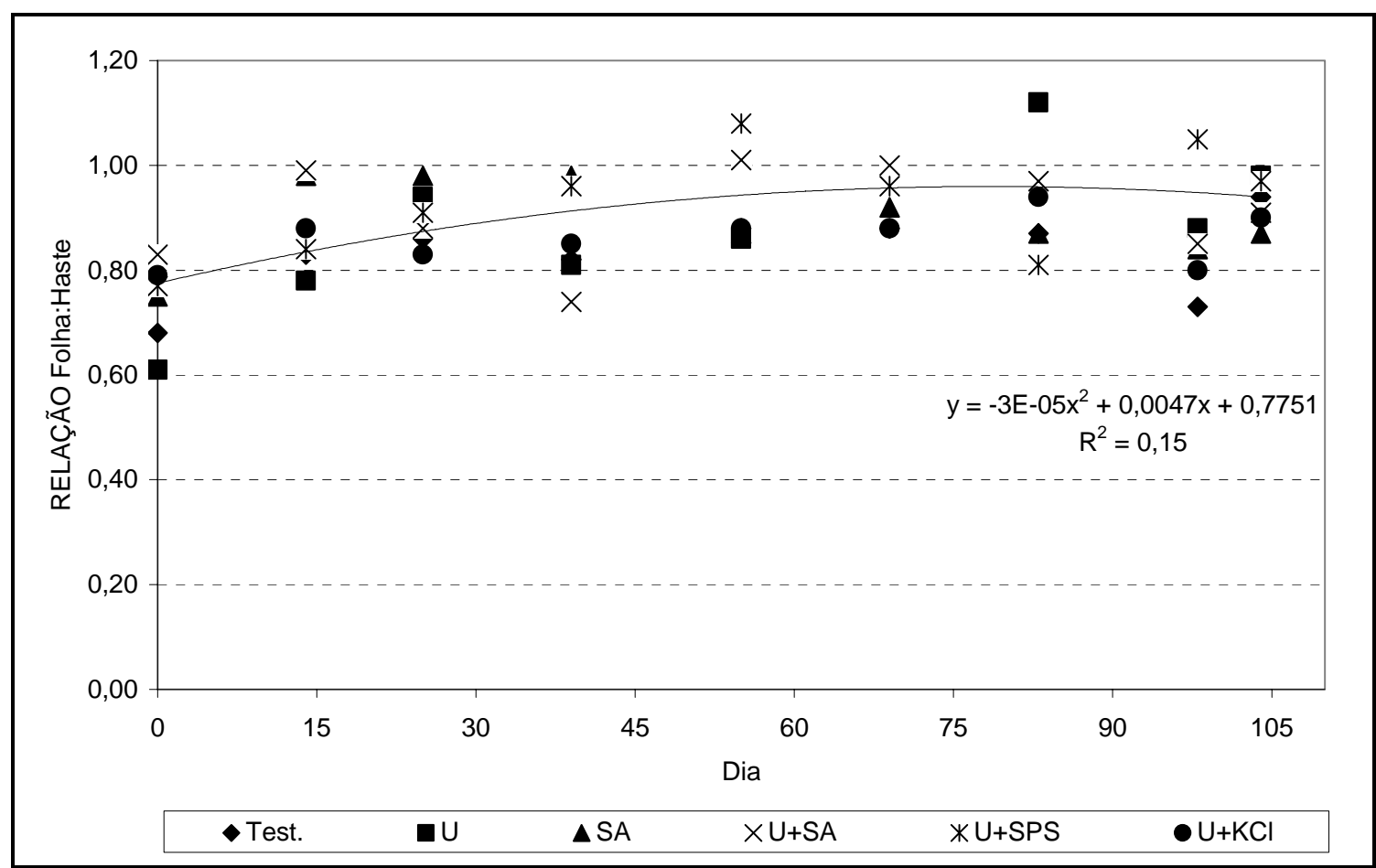

Avaliações realizadas nos dias 22 de março, 06 de abril, 17 de abril, 01 de maio, 17 de maio, 31 de maio, 14 de junho, 29 de junho e 5 de julho, aos 0, 14, 25, 39, 55, 69, 83, 98 e 104 dias de crescimento da planta, respectivamente

Figura 12 - Relação folha:haste média dos seis tratamentos ao longo do período de crescimento

A menor proporção de folhas no dossel pode surgir em decorrência do histórico anterior da área diferida. Pastagens mais baixas por ocasião do momento de diferimento podem acumular maior proporção de folhas. Durante o período de vedação as condições de competição por luz, não favoráveis ao 
crescimento, podem resultar em alongamento das hastes, retardando a taxa de aparecimento de folhas, ao ponto dessa ser mais lenta que a taxa de senescência, resultando assim em aumento de hastes e material senescente.

Além das maiores médias de MF total, MF verde e de LFV, os tratamentos $\mathrm{U}$, SA e U+SA também apresentaram os maiores valores médios de MS digestível (Tabela 11). Com exceção do $U$ e U+SPS, os demais tratamentos não apresentaram grandes variações numéricas de MF digestível a partir dos 83 dias de crescimento, fato que pode explicar a tendência de estabilização da MF digestível média dos seis tratamentos a partir dos 55 dias de crescimento (Figura 13).

Tabela 11. Massa de forragem digestível durante o período de crescimento nos seis tratamentos testados

\begin{tabular}{ccccccc}
\hline Dia $^{2}$ & Test. & U & SA & U+SA & U+SPS & U+KCl \\
\hline R1 $^{3}$ & 1450,56 & 1278,52 & 2072,78 & 1313,59 & 1587,70 & 1652,73 \\
25 & 2513,00 & 2840,07 & 4122,35 & 3383,04 & 2312,46 & 870,60 \\
55 & 2672,49 & 3468,56 & 3786,38 & 4204,36 & 2648,68 & 3117,64 \\
83 & 3129,54 & 4912,66 & 4157,06 & 3401,46 & 3163,93 & 3632,78 \\
Prod $^{4}$ & 2775,71 & 2907,35 & 4091,44 & 3742,33 & 2678,72 & 3756,72 \\
Média $^{1}$ & $2629,4^{\text {b }}$ & $3191,1^{\text {ab }}$ & $3544,2^{\text {a }}$ & $3061,1^{\text {ab }}$ & $2654,8^{\text {b }}$ & $2781,8^{\text {b }}$ \\
\hline
\end{tabular}

${ }^{1}$ Médias seguidas por mesma letra, minúscula na linha, não diferem entre si pelo teste de Tukey $(p>0,05)$

${ }^{2}$ Período compreendido entre os dias 22 de março de 2003 e 05 de julho de 2003

${ }^{3}$ Valores relativos ao resíduo após o pastejo de uniformização da área experimental. Dia 0

${ }^{4}$ Valores relativos à produção final de forragem aos 104 dias de vedação

Os efeitos de momento de avaliação apresentaram comportamento quadrático para MF total, MF verde, LFV e MF digestível (Figura 13). O máximo acúmulo de forragem ocorreu aos 77, 63, 63 e 78 dias para MS, MSV, LFV e MS digestível, respectivamente. Observando-se a inflexão das curvas e as datas quando ocorreram os pontos de máxima produção de forragem das 
mesmas, pode-se observar que o principal determinante do acúmulo de MS digestível foi o acúmulo de MS total e que a MSV foi dependente em grande parte da massa de LFV do dossel forrageiro.

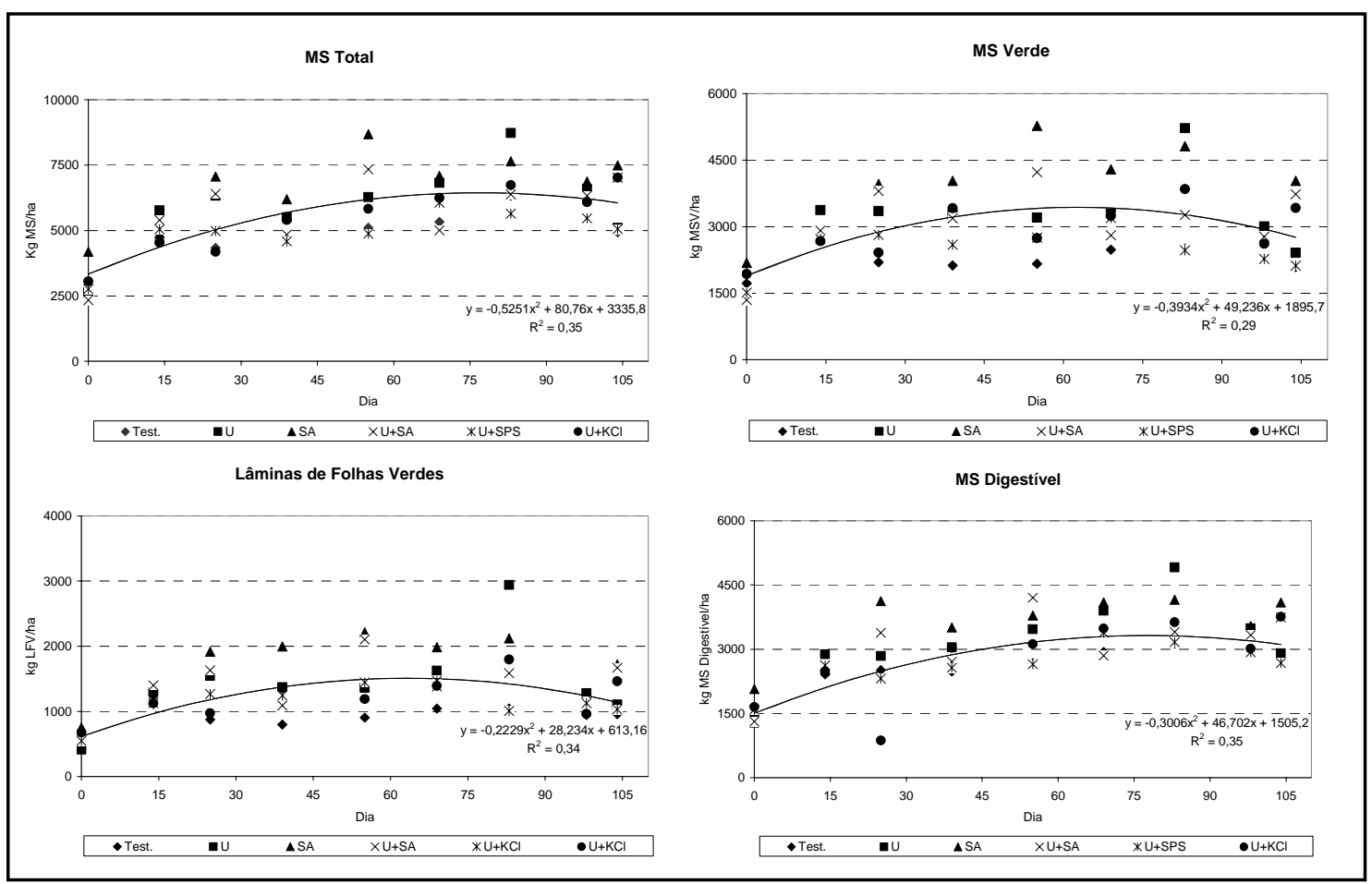

Avaliações realizadas nos dias 22 de março, 06 de abril, 17 de abril, 01 de maio, 17 de maio, 31 de maio, 14 de junho, 29 de junho e 5 de julho, aos 0, 14, 25, 39, 55, 69, 83, 98 e 104 dias de crescimento da planta, respectivamente

Figura 13 - Acúmulo de forragem total, forragem verde, lâminas de folhas verdes e forragem digestível média dos diferentes tratamentos durante o período de crescimento

A tendência de estabilização e redução na massa de forragem no final do período de crescimento (Figura 13) poderia ser explicada por um aumento da interceptação luminosa do dossel forrageiro, o que provocaria aumentos nas taxas de senescência e decomposição dos tecidos da planta. A competição por luz provoca alongamento das hastes, retardando a taxa de aparecimento de folhas, ao ponto dessa ser mais lenta que a taxa de senescência, resultando assim reduções na massa de forragem acumulada. 
Os processos de decomposição e senescência também podem ter sido acelerados dado ao possível desenvolvimento de fungos saprófitos, como relatado por Reis et al. (1996) e Gomes (2003), citando Preston \& Leng (1987). Esses fungos provocariam o desaparecimento mais rápido do material senescente e contribuiria para obtenção de reduções na massa de forragem acumulada.

Através das regressões da Figura 13, pôde-se calcular as taxas médias de acúmulo de forragem total, verde, de lâminas de folhas verdes e de forragem digestível, como apresentado na Tabela 12. Observa-se que em todas as variáveis analisadas houve redução na taxa média de acúmulo de forragem, sendo em média de 48,8; 25,3; 14,7 e 28,4 kg.ha-1. dia ${ }^{-1}$ para MS, MSV, LFV e MS digestível, respectivamente.

Tabela 12. Taxa média de acúmulo de forragem dos seis tratamentos ao longo do período de crescimento

\begin{tabular}{ccccc}
\hline Dia $^{1}$ & MS & MSV & LFV & MS digestível \\
\hline & $73,4^{3}$ & 43,7 & 25,1 & 42,5 \\
25 & 67,6 & 39,4 & 22,7 & 39,2 \\
39 & 60,3 & 33,9 & 19,5 & 35,0 \\
55 & 51,9 & 27,6 & 16,0 & 30,2 \\
69 & 44,5 & 22,1 & 12,9 & 26,0 \\
83 & 37,2 & 16,6 & 9,7 & 21,8 \\
98 & 29,3 & 10,7 & 6,4 & 17,2 \\
Prod $^{2}$ & 26,1 & 8,3 & 5,1 & 15,4 \\
\hline
\end{tabular}

${ }^{1}$ Período compreendido entre os dias 22 de março de 2003 e 05 de julho de 2003

${ }^{2}$ Valores relativos à produção final de forragem aos 104 dias de vedação

3 Valores calculados a partir das regressões subtraindo-se a massa de forragem na data avaliada pelo valor de R1 e dividindo-se o resultado pelo número de dias de crescimento

Além das regressões presentes na Figura 13, calculadas em função dos dias de crescimento da planta, foram também determinadas as regressões de 
acúmulo de forragem total, forragem verde e LFV em função de graus-dia (GD) e unidades fototérmicas (UF) acumulados no período (Figuras 14 e 15).

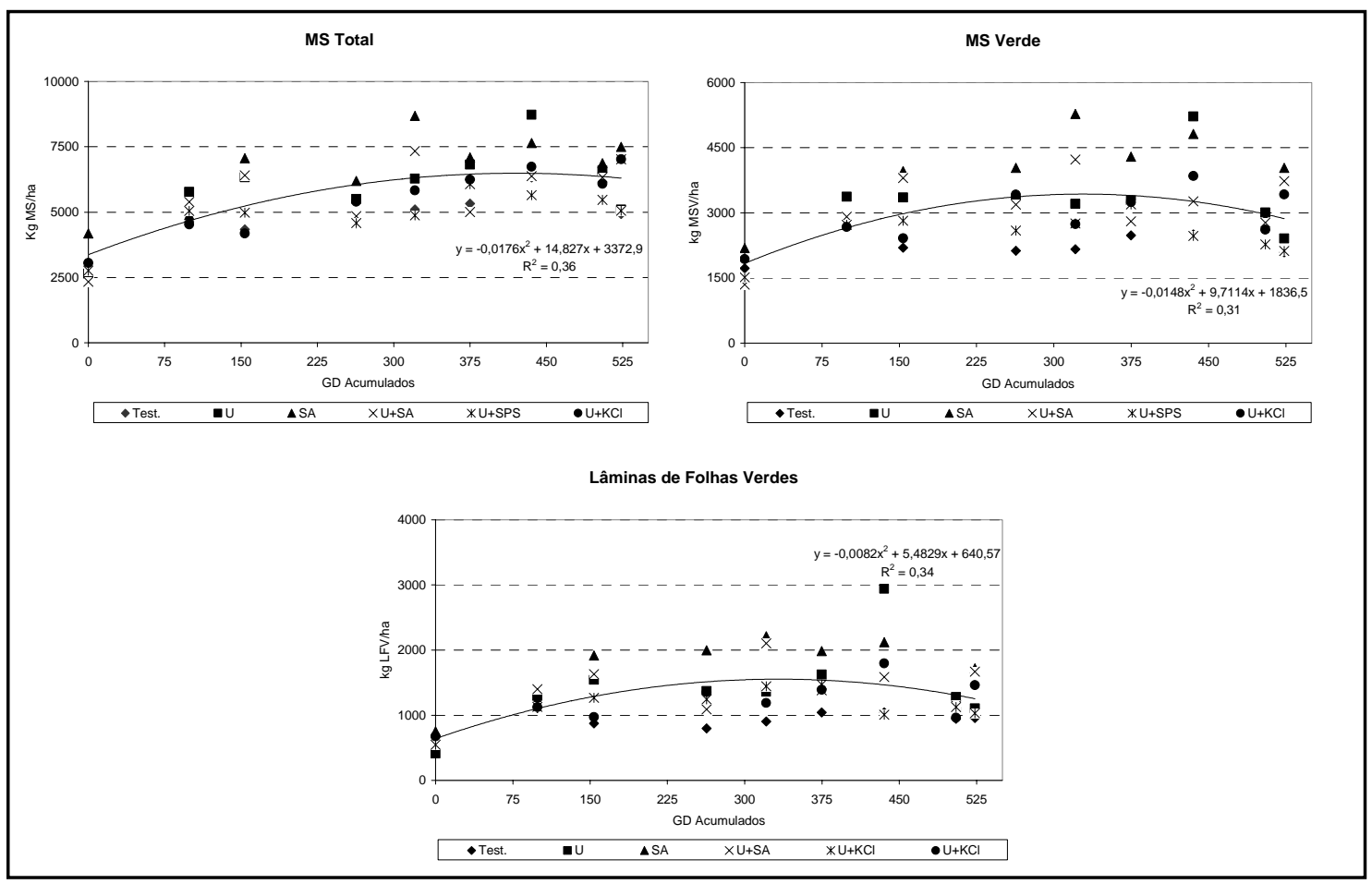

Figura 14 - Acúmulo de forragem total, forragem verde e lâminas de folhas verdes médio dos diferentes tratamentos em função dos GD acumulados durante o período de crescimento

O acúmulo de MF total, MF verde e LFV em função dos GD e UF acumulados durante o período de crescimento apresentaram comportamento quadrático (Figura 14 e 15). O máximo acúmulo de forragem ocorreu aos 421, 328 e 429 GD e às 3855, 2709 e 3033 UF para MS, MSV e LFV, respectivamente.

Ao contrário do observado por Tonato (2003) e Villa Nova et al. (1999), os coeficientes de determinação encontrados tanto para GD quanto para UF não foram altos, ao redor de 0,30, valores próximos à avaliação diária. A principal explicação para esse fato seria a presença de déficit hídrico no período, 
fazendo com que o ajuste do acúmulo de forragem para temperatura e luminosidade sofressem interferência da falta de água no solo.

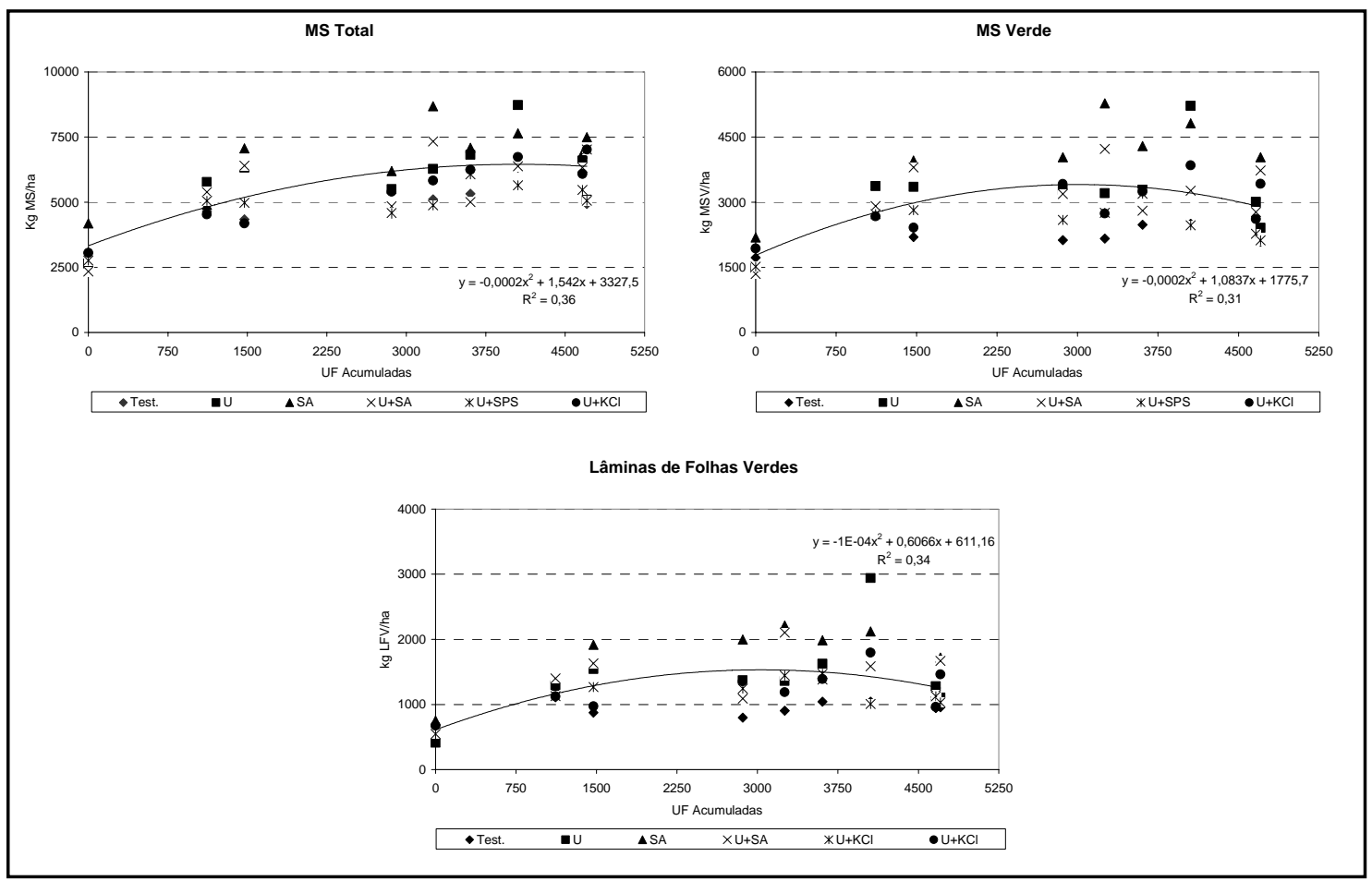

Figura 15 - Acúmulo de forragem total, forragem verde e lâminas de folhas verdes médio dos diferentes tratamentos em função das UF acumulados durante o período de crescimento

\subsubsection{Recuperação Aparente do nitrogênio aplicado}

Não houve efeito de época e de interação entre tratamento e época para a recuperação aparente do nitrogênio (Tabela 13). A média do SA foi superior às dos demais tratamentos, não diferindo apenas da U. Como a recuperação aparente é o produto de duas determinações independentes, o teor de $\mathrm{N} \mathrm{e} \mathrm{a}$ massa de forragem, a variabilidade dos dados obtidos também acaba sendo o produto das variabilidades dessas duas determinações, fazendo com que elas sejam provavelmente potencializadas, anulando assim o efeito entre épocas. 
Tabela 13. Recuperação aparente do nitrogênio aplicado via fertilizante ao longo do período de crescimento

\begin{tabular}{cccccc}
\hline Dia $^{2}$ & $\mathrm{U}$ & $\mathrm{SA}$ & $\mathrm{U}+\mathrm{SA}$ & $\mathrm{U}+\mathrm{SPS}$ & $\mathrm{U}+\mathrm{KCl}$ \\
\hline & $---{ }^{2}$ & 12,8 & 10,8 & 35,8 & 27,0 \\
25 & 21,0 & 76,6 & 25,9 & 13,7 & 0,0 \\
55 & 49,1 & 134,4 & 35,4 & 2,2 & 4,1 \\
83 & 40,8 & 27,6 & 9,4 & 3,4 & 30,8 \\
Prod $^{3}$ & 10,3 & 20,3 & 18,4 & 3,1 & 10,7 \\
Média $^{1}$ & $25,0^{\mathrm{ab}}$ & $44,7^{\mathrm{a}}$ & $18,1^{\mathrm{b}}$ & $8,3^{\mathrm{b}}$ & $12,0^{\mathrm{b}}$ \\
\hline
\end{tabular}

${ }^{1}$ Médias seguidas por mesma letra, minúscula na linha, não diferem entre si pelo teste de Tukey $(p>0,05)$

${ }^{2}$ Período compreendido entre os dias 22 de março de 2003 e 05 de julho de 2003

${ }^{3}$ Valores relativos à produção final de forragem aos 104 dias de vedação

Os cálculos de estimativa de recuperação aparente do $\mathrm{N}$ permitem que alguns valores sejam superiores a 100\%, como é o caso do SA aos 55 dias de crescimento. Esse resultado está de acordo com o obtido por Werner et al. (1967), e poderia ser explicado pelo fato de que as plantas adubadas seriam capazes de explorar maior volume de solo, podendo acumular quantidades elevadas de nitrogênio. Segundo Martha Júnior (2003), a recuperação aparente do $\mathrm{N}$ não considera as diferenças entre o nitrogênio existente no solo e o do fertilizante, sendo possível obter resultados acima dos $100 \%$ de recuperação.

Em todos os tratamentos, com exceção do U+SPS e U+KCl, o pico de recuperação aparente foi próximo dos 55 dias de crescimento (Figura 16). Comparando as massas de forragem dos tratamentos que receberam fertilizante nitrogenado em relação à testemunha (Tabela 8), nota-se que as diferenças entre elas estão de acordo com os resultados da Figura 16, onde o SA apresentou maior recuperação até os 55 dias, porém com redução mais acentuada após esse período; enquanto que nos tratamentos $\mathrm{U}+\mathrm{SA}$ e $\mathrm{U}+\mathrm{KCl}$ verificaram-se picos de recuperação de menor magnitude, com posterior decréscimo desses valores em ritmo menos acelerado. Já o tratamento $U$ 
situou-se em ponto intermediário entre o $\mathrm{SA}$ e o $\mathrm{U}+\mathrm{KCl}$ e $\mathrm{U}+\mathrm{SA}$, sendo o comportamento no decorrer do período semelhante aos três tratamentos. O tratamento U+SPS foi o que mais se aproximou à testemunha em valores de massa de forragem, o que poderia explicar seus valores mais baixos de recuperação do nitrogênio aplicado.

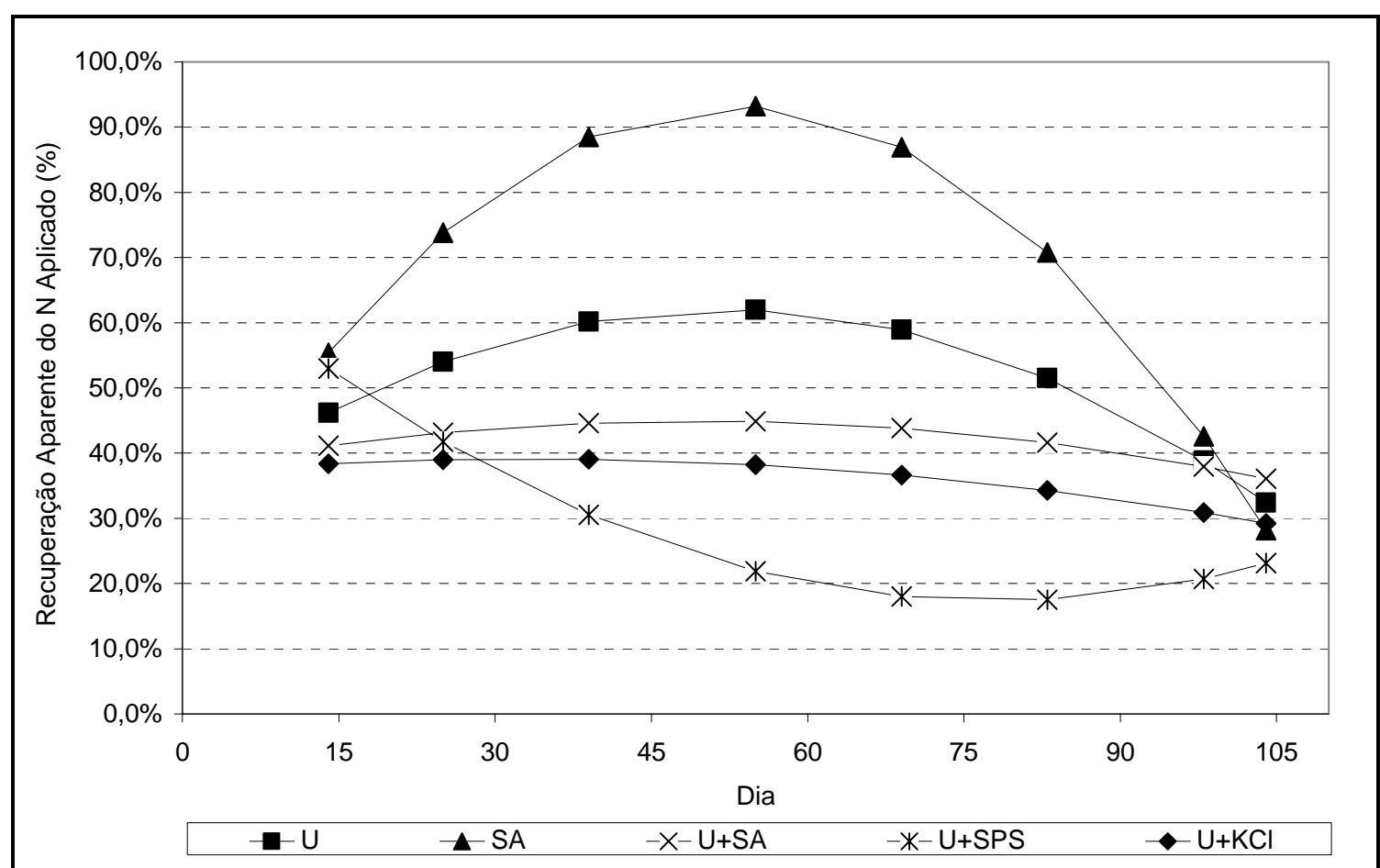

Avaliações realizadas nos dias 22 de março, 06 de abril, 17 de abril, 01 de maio, 17 de maio, 31 de maio, 14 de junho, 29 de junho e 5 de julho, aos 0, 14, 25, 39, 55, 69, 83, 98 e 104 dias de crescimento da planta, respectivamente

Figura 16 - Recuperação aparente do nitrogênio aplicado via fertilizante ao longo do período de crescimento para os diferentes tratamentos

Paulino et al. (1995), estudando o uso de fontes de nitrogênio no momento do diferimento em $B$. decumbens, determinaram a recuperação aparente do nitrogênio ao longo de 173 dias de crescimento da planta. Os resultados foram maiores para o SA aos 89 dias de crescimento (50\% de recuperação do nitrogênio), decaindo posteriormente ao redor de 10 a 15\% aos 173 dias, comportamento semelhante ao observado para o tratamento SA, porém em 
menor magnitude. Para a uréia e uréia associada com sulfato de magnésio a recuperação aparente foi estável, com valores de $20 \%$ até os 117 dias de crescimento, quando houve redução gradativa a valores abaixo dos $10 \%$ até o final do período, fato também observado para os tratamentos U+SA e U+KCl, porém estes se encontraram em patamares mais elevados.

Tabela 14. Equações utilizadas para gerar as curvas de recuperação aparente do $\mathrm{N}$ aplicado

\begin{tabular}{ccc}
\hline Tratamento & Regressão & $\mathrm{R}^{2}$ \\
\hline U & $0,3229+0,0115 \times-0,000110 \mathrm{x}^{2}$ & 0,35 \\
$\mathrm{SA}$ & $0,2327+0,0265 \mathrm{x}-0,000250 \mathrm{x}^{2}$ & 0,35 \\
$\mathrm{U}+\mathrm{SA}$ & $0,3754+0,0030 \mathrm{x}-0,000030 \mathrm{x}^{2}$ & 0,35 \\
$\mathrm{U}+\mathrm{SPS}$ & $0,7027-0,0136 \mathrm{x}+0,000087 \mathrm{x}^{2}$ & 0,35 \\
$\mathrm{U}+\mathrm{KCl}$ & $0,3684+0,0014 \mathrm{x}-0,000020 \mathrm{x}^{2}$ & 0,35 \\
\hline
\end{tabular}

Independentemente das diferenças médias de recuperação aparente entre os tratamentos, e das diferentes variações de cada fertilizante ao longo do período de crescimento, aos 14 e aos 104 dias de crescimento as eficiências de absorção do adubo aplicado foram próximas. No início do período de crescimento isso poderia ser explicado pela massa residual de forragem ainda pequena, o que limitaria a eficiência de absorção de nutrientes. Já aos 104 dias, a causa desse nivelamento poderia ser explicada pelas massas e taxas de acúmulo de forragem semelhantes entre os tratamentos (Tabelas 8 e 12; Figura 13). 


\subsection{Período de Pastejo}

\subsubsection{Parâmetros Produtivos}

Os resultados discutidos a seguir representam os valores obtidos das coletas a partir da entrada dos animais em pastejo, ou seja, depois de 104 dias de crescimento. Desse modo, o resultado apresentado nas Tabelas 8 e 9 para 104 dias são os mesmos que os apresentados na semana zero do período de pastejo (Prod.).

Não houve efeito de tratamento nem de interação com o momento de avaliação para todos os parâmetros avaliados (Tabela 15). Dessa forma, serão discutidos apenas os valores referentes ás médias dos momentos de coleta dessas variáveis.

Tabela 15. Parâmetros produtivos médios dos seis tratamentos testados ao longo do período de pastejo

\begin{tabular}{cccccc}
\hline Semana $^{2}$ & $\begin{array}{c}\text { Altura } \\
(\mathrm{cm})\end{array}$ & \multicolumn{2}{c}{ Massa de Forragem } & \multicolumn{2}{c}{$\begin{array}{c}\text { Densidade Volumétrica } \\
\text { da Forragem }\end{array}$} \\
& & MSV & MS & MSV & MS $^{1}$ \\
\hline Prod. $^{4}$ & $29,8^{\mathrm{A}}$ & $2636,9^{\mathrm{A}}$ & $6093,9^{\mathrm{A}}$ & $88,5^{\mathrm{A}}$ & $214,5^{\mathrm{A}}$ \\
2 & $23,0^{\mathrm{BC}}$ & $1169,2^{\mathrm{B}}$ & $4775,2^{\mathrm{AB}}$ & $50,8^{\mathrm{B}}$ & $217,6^{\mathrm{A}}$ \\
4 & $25,7^{\mathrm{B}}$ & $629,9^{\mathrm{C}}$ & $5589,8^{\mathrm{A}}$ & $24,5^{\mathrm{C}}$ & $222,7^{\mathrm{A}}$ \\
6 & $24,1^{\mathrm{BC}}$ & $561,8^{\mathrm{C}}$ & $4030,8^{\mathrm{B}}$ & $23,6^{\mathrm{C}}$ & $181,2^{\mathrm{AB}}$ \\
8 & $21,2^{\mathrm{CD}}$ & $0,0^{\mathrm{D}}$ & $2672,3^{\mathrm{C}}$ & $0,0^{\mathrm{D}}$ & $129,1^{\mathrm{C}}$ \\
R2 $^{3}$ & $20,0^{\mathrm{D}}$ & $0,0^{\mathrm{D}}$ & $2632,0^{\mathrm{C}}$ & $0,0^{\mathrm{D}}$ & $139,3^{\mathrm{BC}}$
\end{tabular}

\footnotetext{
${ }^{1}$ Médias seguidas por mesma letra, maiúscula na coluna, não diferem entre si pelo teste de Tukey $(p>0,05)$

${ }^{2}$ Período compreendido entre os dias 14 de julho de 2003 e 20 de setembro de 2003

${ }^{3}$ Resíduo do período de pastejo ao final da $9^{\underline{a}}$ semana, coletado no dia 20 de setembro de 2003

${ }^{4}$ Semana 0 do período de pastejo, equivalente aos 104 dias do período de crescimento
} 
Houve queda acentuada na massa de forragem total, na massa de forragem verde e na altura do dossel durante o período de pastejo (Tabela 15), sendo provavelmente o principal fator determinante desses decréscimos 0 consumo de forragem pelos animais em pastejo. A MSV decresceu em um ritmo mais acelerado que a MS total, e esta em uma velocidade maior que a altura (Figura 17).

A diferença nos ritmos de redução dessas respostas se deve ao fato dos animais preferirem folhas verdes em detrimento de colmos e material senescido. No início do período de pastejo ocorreu maior consumo de forragem verde, preferencialmente de folhas, até o momento em que os animais foram incapazes de coletar tal material, a partir da terceira semana de pastejo (Figura 17). Além do consumo preferencial de forragem verde pelo animal, durante o final do período de crescimento e durante o período de pastejo o material verde também senesce sem que sua renovação seja integral, prejudicada pelos fatores ambientais inerentes da época do ano, como indicam as tendências observadas na Figura 13 a partir de 63 dias.

A preferência dos animais pelas folhas verdes foi documentada por trabalho de Chacon \& Stobbs (1976), que determinaram a participação de folhas, hastes e material senescido na dieta do animal ao longo de 15 dias de pastejo em Setaria anceps cv. Kazungula após 9 semanas de crescimento. A proporção de folhas na dieta foi de quase $100 \%$ quando ela compunha $35 \%$ da forragem ofertada, caindo para $56 \%$ quando esse componente representava $7,5 \%$ do total de forragem.

O decréscimo mais lento de MS total no decorrer do período de pastejo (Figura 17) é justificado pela representatividade das hastes, que não são consumidas pelo animal. A partir da sexta semana de pastejo o decréscimo da MF foi significativo (Tabela 15) devido ao consumo de hastes e material morto em conseqüência da ausência de MSV, como foi constatado no trabalho de Barcellos \& Andrade (1993), trabalhando com A. gayanus. Esses autores detectaram que as maiores participações de folhas verdes (FV) na dieta foram 
nos meses de outubro a março, sendo que essa fração foi perdendo representatividade, ao mesmo tempo em que aumentava o consumo de folhas e hastes secas (FS e HS) no final do período de crescimento e início do inverno, quando a dieta apresentava composição de 4,45\% de FV contra $63,46 \%$ de FS e $20,30 \%$ de HS.

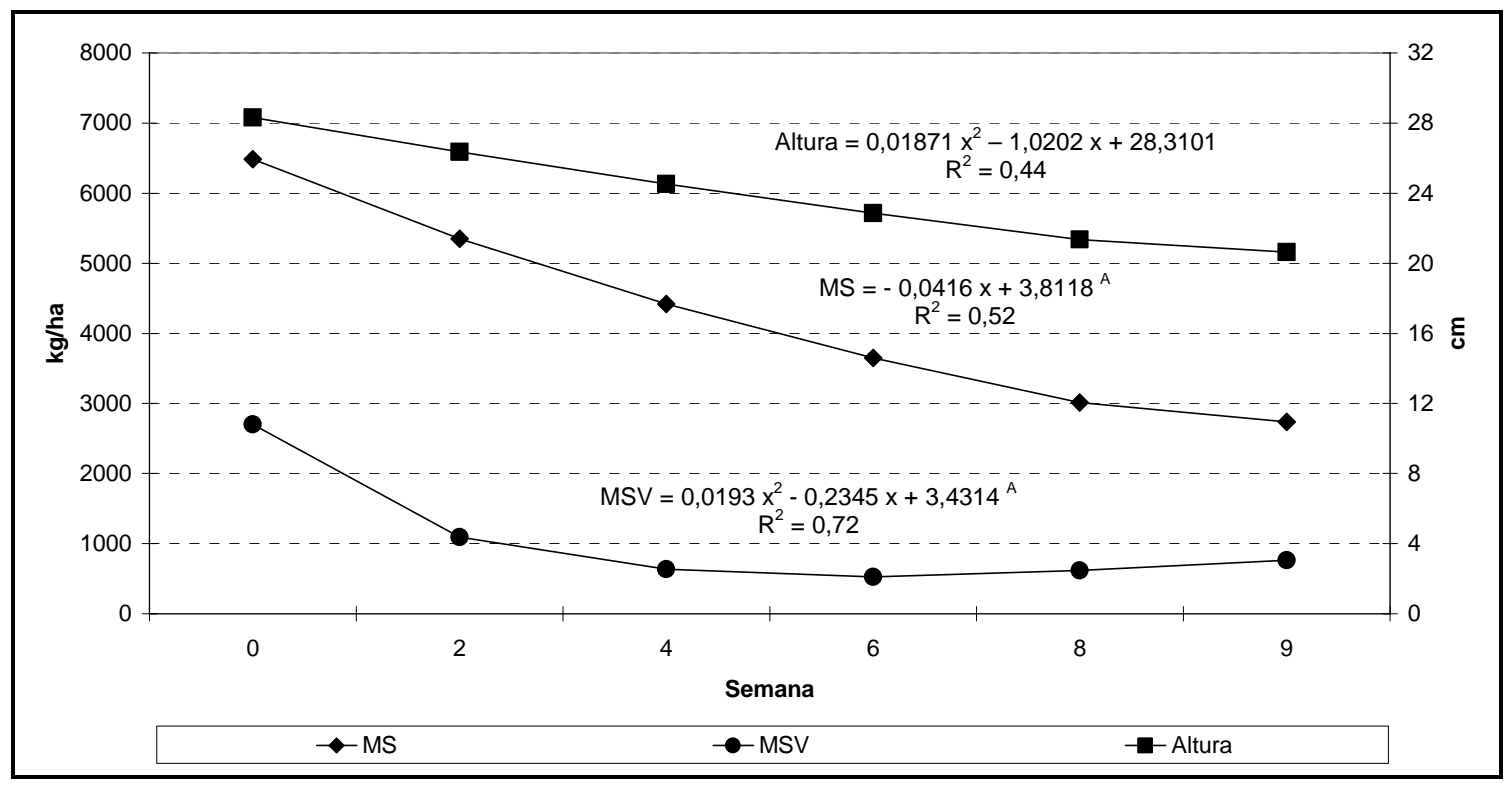

Período compreendido entre os dias 14 de julho de 2003 e 20 de setembro de 2003

A Dados transformados para $\log _{10}$

Figura 17 - Massa de forragem total, forragem verde e altura da pastagem ao longo do período de pastejo

Quando o período de pastejo atingiu a oitava semana, não havia folhas secas ou verdes na pastagem (Figura 9 e Tabela 15), decidindo-se que o experimento de pastejo seria encerrado, embora a aparência do pasto determinado pela altura não desse suporte a essa decisão.

Em resumo, os animais em pastejo consumiram seletivamente as frações folha, principalmente as verdes, deixando as hastes, principalmente as mortas, que garantiram a manutenção da altura do dossel acima dos $20 \mathrm{~cm}$, como pode ser visto através da densidade volumétrica da MSV (Figura 18 e Tabela 15), 
que decresceu rapidamente até estar praticamente ausente no dossel por ocasião do período final de pastejo.

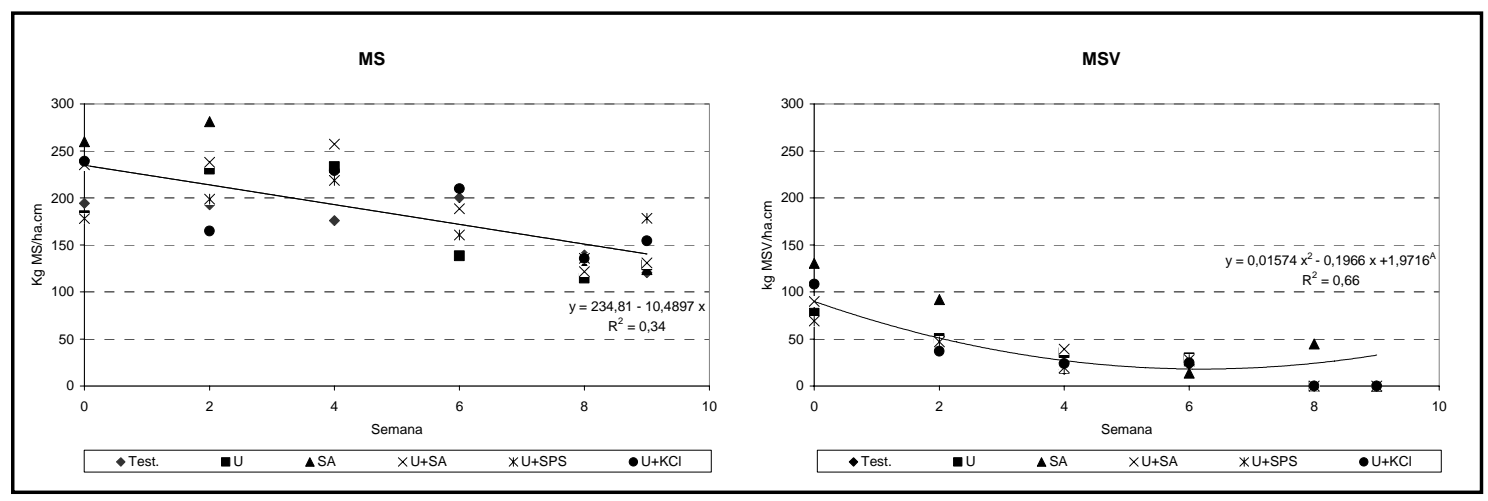

Período compreendido entre os dias 14 de julho de 2003 e 20 de setembro de 2003

A Dados transformados para $\log _{10}$

Figura 18 - Densidade volumétrica da forragem total e verde ao longo do período de pastejo

A densidade de MSV, por apresentar respostas mais rápidas e sensíveis durante o progresso do pastejo na área diferida, pode se constituir em variável mais importante que a altura e a MF para avaliar o status do dossel forrageiro. Por outro lado, a MF, e não a altura da planta, pode ser usada com restrições devido à presença de hastes lignificadas. Trabalhos futuros devem considerar o consumo e a composição morfológica do material senescido, principalmente de folhas mortas, para definir o momento em que o pastejo deve ser interrompido.

As perdas decorrentes do pastejo, foram maiores no início do período

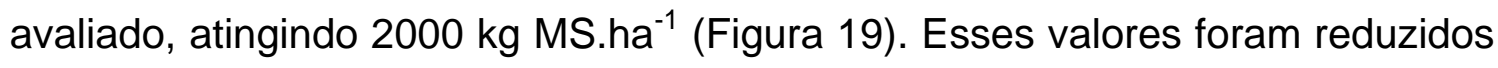
para cerca de $1500 \mathrm{~kg}$ na quinta semana de pastejo em seguida aumentando para $2300 \mathrm{~kg}$ na última semana de avaliação. Isso deveu-se provavelmente à uma maior MF no momento da entrada dos animais, o que pode ter resultado em perdas por acamamento. Com a redução na MF, houve menor propensão a perdas. À medida que o período de pastejo progredia, aumentava a porção de material senescido que desprendia da planta forrageira pela ação do animal, elevando as perdas a partir da sexta semana de uso do pasto. 


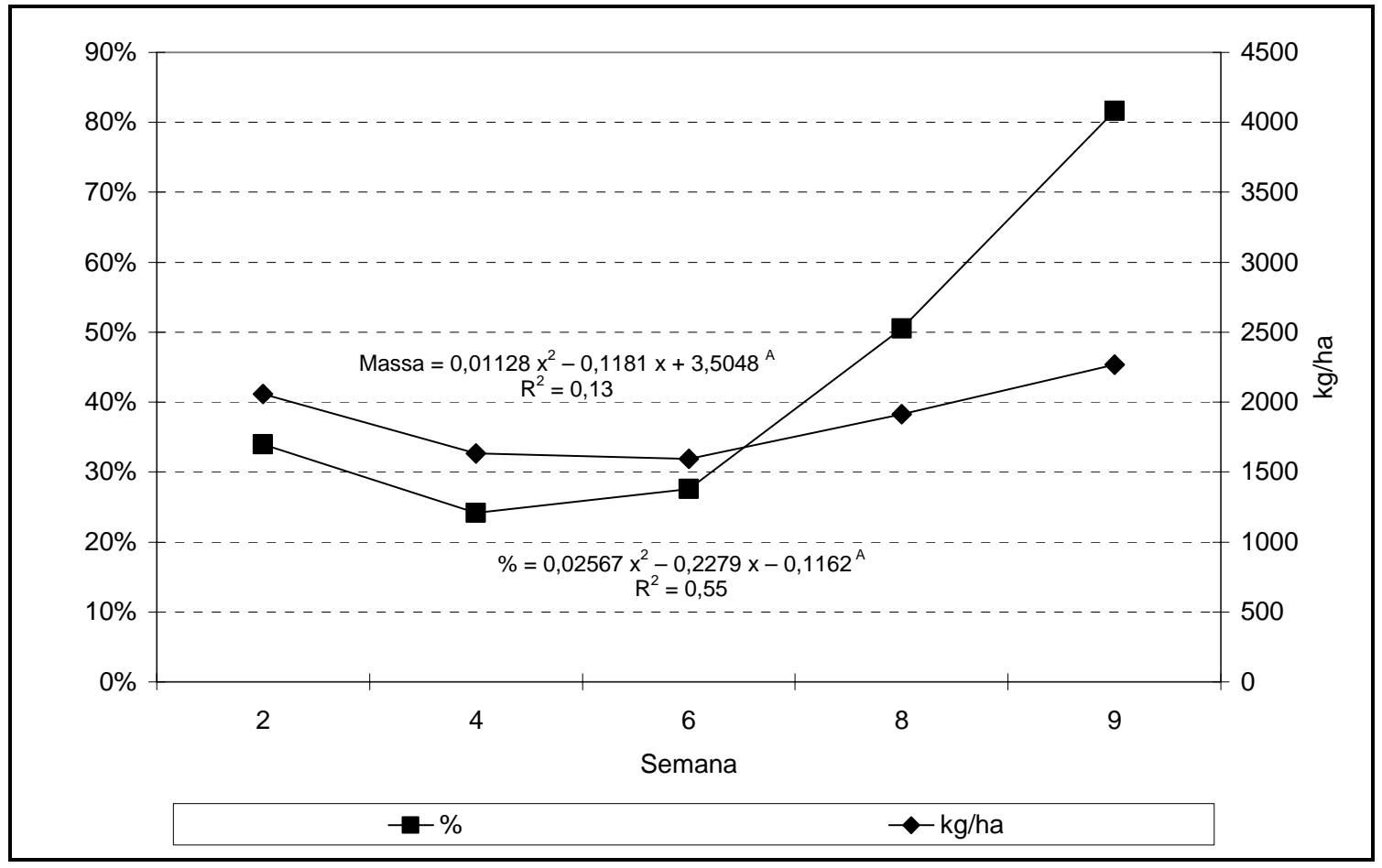

Período compreendido entre os dias 14 de julho de 2003 e 20 de setembro de 2003

A Dados transformados para $\log _{10}$

Figura 19 - Perdas por pastejo, em valores absolutos e relativos, ao longo do período de pastejo

Quanto à proporção de forragem perdida em relação ao total ofertado, houve decréscimo até o final da segunda e início da terceira quinzena, quando ocorreu aumento significativo dessa fração. Esse efeito deve-se principalmente à diminuição da massa de forragem e ligeiro aumento das perdas decorrentes da maior participação de material senescido. Os elevados valores percentuais de perdas no final do pastejo são principalmente conseqüência da menor massa de forragem do que do aumento dos valores absolutos dessa variável, uma vez que esta se iniciou na casa dos $2000 \mathrm{~kg} \mathrm{MS} . \mathrm{ha}^{-1}$, nunca superando os $2500 \mathrm{~kg} \mathrm{MS} \cdot \mathrm{ha}^{-1}$. 


\subsubsection{Valor nutritivo da forragem ofertada e dos pastejos simulados}

Houve diferença entre os tratamentos, épocas de coleta e suas interações em relação aos teores de NDT (Tabela 16).

Plantas adubadas com SA e $\mathrm{U}+\mathrm{KCl}$ apresentaram teores médios de NDT de $52,3 \%$ e $52,2 \%$, respectivamente, e não diferiram dos demais tratamentos adubados, mas foram superiores à testemunha, que apresentou valores de $51,2 \%$. Os decréscimos nos teores de NDT ocorreram entre a quarta e sexta semana de avaliação, passando da média de 52,5\% para 51,5\% nas duas semanas finais do período de pastejo.

Tabela 16. Nutrientes digestíveis totais dos pastejos simulados para os diferentes tratamentos ao longo do período de pastejo

\begin{tabular}{cccccccc}
\hline Semana $^{2}$ & Test. & U & SA & U+SA & U+SPS & U+KCl & Média \\
\hline 2 & $52,2^{\mathrm{A}}$ & $52,6^{\mathrm{A}}$ & $53,5^{\mathrm{A}}$ & $53,1^{\mathrm{A}}$ & $52,8^{\mathrm{A}}$ & $53,0^{\mathrm{A}}$ & $52,9^{\mathrm{A}}$ \\
4 & $51,7^{\mathrm{A}}$ & $52,6^{\mathrm{A}}$ & $52,5^{\mathrm{AB}}$ & $52,8^{\mathrm{A}}$ & $52,3^{\mathrm{A}}$ & $52,7^{\mathrm{A}}$ & $52,5^{\mathrm{A}}$ \\
6 & $51,1^{\mathrm{AB}}$ & $52,2^{\mathrm{A}}$ & $51,9^{\mathrm{AB}}$ & $51,9^{\mathrm{A}}$ & $50,1^{\mathrm{B}}$ & $52,1^{\mathrm{AB}}$ & $51,5^{\mathrm{B}}$ \\
8 & $49,6^{\mathrm{B}}$ & $51,1^{\mathrm{A}}$ & $51,1^{\mathrm{B}}$ & $50,2^{\mathrm{B}}$ & $51,4^{\mathrm{AB}}$ & $50,8^{\mathrm{B}}$ & $50,7^{\mathrm{B}}$ \\
Média & $51,2^{\mathrm{b}}$ & $52,1^{\mathrm{ab}}$ & $52,3^{\mathrm{a}}$ & $52,0^{\mathrm{ab}}$ & $51,6^{\mathrm{ab}}$ & $52,2^{\mathrm{a}}$ & \\
\hline
\end{tabular}

${ }^{1}$ Valores seguidos por mesma letra, minúscula na linha e maiúscula na coluna, não diferem entre si pelo teste de Tukey $(p>0,05)$

${ }^{2}$ Período compreendido entre os dias 14 de julho de 2003 e 20 de setembro de 2003

Para as plantas adubadas com $U$, o início do pastejo se deu com teores de $52,6 \%$ de NDT, mantendo-se constante ao longo do período; enquanto as adubadas com SA apresentavam concentrações de 53,5\% de NDT no início, diminuindo para $51,1 \%$ da MS no final do período de pastejo. As plantas forrageiras que receberam U+SA mantiveram os teores de NDT até a sexta semana de pastejo. Essas variações são importantes, uma vez que a diferença dos teores de NDT do tratamento testemunha $(51,2 \%)$ e do SA $(52,3 \%)$ podem 
refletir em diferenças de ganhos diários, calculados através de equações propostas pelo NRC (1996), de $52 \mathrm{~g}$ em animais zebuínos não castrados de $450 \mathrm{~kg}$ de PV. Por outro lado, o decréscimo do NDT médio de 52,9\% para $50,7 \%$ do início até o final do período de pastejo, respectivamente, determinaria reduções de ganho diário de $63 \mathrm{~g} \cdot \mathrm{cab}^{-1}$.

As diferenças nos teores de NDT no decorrer do período de pastejo parecem ser inevitáveis, uma vez que o aparecimento de tecidos novos na planta é limitado pelas condições climáticas, e a senescência associada ao consumo da forragem de melhor valor nutritivo (VN) conduz aos decréscimos qualitativos da forragem em oferta. Alterando-se a oferta de forragem pode-se prorrogar a existência de MF de melhor VN. Assim, poderia ser recomendado o uso de pastagens diferidas a animais mais exigentes através do aumento da oferta de forragem, o que melhoraria a capacidade de seleção do material ofertado.

Reis (2000), determinou o valor nutritivo de $B$. brizantha em diferentes idades de corte. Com base nesses dados, foi calculado que o NDT para a planta aos 120 dias de crescimento seria de 43\%, valor inferior aos apresentados na Tabela 16. Nesse experimento a forragem recebeu $120 \mathrm{~kg}$ $\mathrm{N} . \mathrm{ha}^{-1}$, além de se desenvolver durante estação mais propícia ao crescimento (5 de dezembro a 5 de abril) caracterizada por maiores temperaturas e quantidades de chuva mais abundantes. Isso pode ter causado um crescimento mais acelerado da planta, seguido de um acúmulo mais acentuado de componentes estruturais, influenciando negativamente no valor estimado do NDT. Além disso, os dados da Tabela 16 foram determinados com base no pastejo simulado, enquanto que Reis (2000) realizou sua avaliação com base na planta toda, onde a maior participação da fração haste pode ter contribuído para o menor valor estimado de NDT.

Os resultados de PB, FDN, FDA, DIVMS e Lignina foram interpretados comparando-se o $\mathrm{VN}$ da forragem ofertada para os diferentes tratamentos com a média dos valores determinados no material colhido através da simulação do 
pastejo. Essa comparação foi possível devido ao fato de que não houve diferenças entre os tratamentos para as variáveis químico-bromatológicas no pastejo simulado.

Os teores de PB não foram diferentes entre os tratamentos (Tabela 17). Pizarro et al. (1996) e Gomes (2003), obtiveram valores de 3,5\% PB em B. decumbens e $B$. brizantha com 110 dias de crescimento, respectivamente. Entretanto, os resultados da Tabela 17 são inferiores aos obtidos por Leite et al. (1998), onde a PB de três cultivares e $B$. brizantha diferidas a partir de março foram entre 5 e $6 \%$. No entanto, esse último autor obteve produções de MS de forragem inferiores aos $3500 \mathrm{~kg} \cdot \mathrm{ha}^{-1}$, o que poderia ter causado um efeito de concentração de $\mathrm{N}$ na forragem avaliada.

Tabela 17. Teor de PB da forragem ofertada nos diferentes tratamentos e da média dos pastejos simulados ao longo do período de pastejo

\begin{tabular}{|c|c|c|c|c|c|}
\hline \multirow{2}{*}{ Tratamento } & \multicolumn{4}{|c|}{ 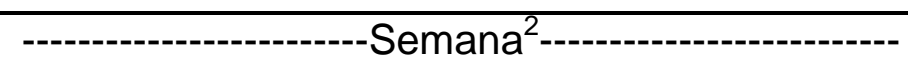 } & \multirow{2}{*}{ Média $^{1}$} \\
\hline & 2 & 4 & 6 & 8 & \\
\hline & --------- & - & 0 da N & ----- & -------- \\
\hline Test. & 3,8 & 2,9 & 2,8 & 2,9 & $3,1^{\mathrm{B}}$ \\
\hline$U$ & 4,5 & 3,2 & 2,9 & 3,2 & $3,4^{\mathrm{AB}}$ \\
\hline SA & 4,4 & 3,4 & 3,0 & 3,1 & $3,5^{A B}$ \\
\hline $\mathrm{U}+\mathrm{SA}$ & 3,7 & 3,0 & 3,1 & 3,0 & $3,2^{A B}$ \\
\hline U+SPS & 3,9 & 3,1 & 2,9 & 2,9 & $3,2^{A B}$ \\
\hline $\mathrm{U}+\mathrm{KCl}$ & 4,3 & 3,2 & 3,1 & 3,2 & $3,4^{A B}$ \\
\hline $\mathrm{Sim}^{3}$ & 4,4 & 3,7 & 3,1 & 3,1 & $3,6^{A}$ \\
\hline Média & $4,1^{a}$ & $3,2^{b}$ & $3,0^{b}$ & $3,0^{b}$ & \\
\hline
\end{tabular}

${ }^{1}$ Médias seguidas por mesma letra, minúscula na linha e maiúscula na coluna, não diferem entre si pelo teste de Tukey $(p>0,05)$

${ }^{2}$ Período compreendido entre os dias 14 de julho de 2003 e 20 de setembro de 2003

${ }^{3}$ Médias das amostras de pastejos simulados dos seis tratamentos

Os teores médios de PB foram superiores na segunda semana e não diferiram entre si a partir da quarta semana de pastejo (Tabela 17), ao contrário 
do observado para os teores de FDN (Tabela 18), onde os maiores teores ocorreram na quarta quinzena de pastejo, e os menores na primeira e terceira quinzenas, com teores intermediários na quarta semana de avaliação.

O pastejo simulado (PS) foi igual à MF ofertada nos diferentes tratamentos, sendo os teores obtidos inferiores aos de Gomes (2003), que obteve em B. brizantha diferida em março e utilizada em julho 77\% de FDN; e superiores aos obtidos por Leite et al. (1998), onde a FDN de três cultivares de B. brizantha utilizadas em julho foram entre 65 e $67 \%$. O primeiro autor, não indica em sua metodologia de análise se foi utilizado ou não sulfito de sódio na determinação da FDN, o que certamente elevaria os teores da mesma caso a afirmativa seja negativa. Já no segundo trabalho, as produções de MS de forragem foram inferiores aos $3500 \mathrm{~kg} \mathrm{ha}^{-1}$, o que certamente resultaria em menor acúmulo de componentes estruturais nos tecidos.

Tabela 18. Teor de FDN da forragem ofertada nos diferentes tratamentos e da média dos pastejos simulados ao longo do período de pastejo

\begin{tabular}{|c|c|c|c|c|c|}
\hline \multirow{2}{*}{ Tratamento } & \multicolumn{4}{|c|}{--- } & \multirow{2}{*}{ Média ${ }^{1}$} \\
\hline & 2 & 4 & 6 & 8 & \\
\hline & \multicolumn{5}{|c|}{ 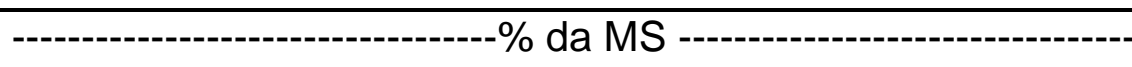 } \\
\hline Test. & 70,1 & 73,9 & 69,5 & 73,0 & $71,6^{\mathrm{AB}}$ \\
\hline$U$ & 68,3 & 72,4 & 66,8 & 73,2 & $70,2^{\mathrm{B}}$ \\
\hline SA & 69,7 & 71,7 & 68,5 & 74,3 & $71,0^{\mathrm{AB}}$ \\
\hline$U+S A$ & 71,5 & 74,0 & 71,7 & 77,0 & $73,5^{A}$ \\
\hline U+SPS & 70,9 & 72,0 & 70,1 & 77,0 & $72,5^{\mathrm{AB}}$ \\
\hline $\mathrm{U}+\mathrm{KCl}$ & 69,7 & 71,9 & 69,7 & 72,2 & $70,9^{\mathrm{AB}}$ \\
\hline $\operatorname{Sim}^{3}$ & 70,3 & 72,3 & 73,9 & 74,5 & $72,7^{\mathrm{AB}}$ \\
\hline Média & $70,1^{c}$ & $72,6^{b}$ & $70,0^{c}$ & $74,4^{\mathrm{a}}$ & \\
\hline
\end{tabular}

${ }^{1}$ Médias seguidas por mesma letra, minúscula na linha e maiúscula na coluna, não diferem entre si pelo teste de Tukey $(p>0,05)$

${ }_{2}^{2}$ Período compreendido entre os dias 14 de julho de 2003 e 20 de setembro de 2003

${ }^{3}$ Médias das amostras de pastejos simulados dos seis tratamentos 
Bueno et al. (2000) estudando diferentes estratégias de diferimento e utilização de $B$. brizantha na região de Brotas-SP, determinaram que as plantas diferidas ao final de março e utilizadas em Julho apresentaram valores de FDN de cerca de 70\%, sendo estes semelhantes aos observados na Tabela 18. As épocas de diferimento e utilização também foram as mesmas para ambos os trabalhos, indicando consistência nos dados.

Tabela 19. Teor de FDA da forragem ofertada nos diferentes tratamentos e da média dos pastejos simulados ao longo do período de pastejo

\begin{tabular}{|c|c|c|c|c|c|}
\hline \multirow{2}{*}{ Tratamento } & \multicolumn{4}{|c|}{-----------------------Semana ${ }^{2}---------------------$} & \multirow{2}{*}{ Média $^{1}$} \\
\hline & 2 & 4 & 6 & 8 & \\
\hline & - & - & o da M & $-\overline{---}$ & 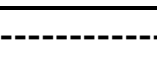 \\
\hline Test. & 34,0 & 36,9 & 35,3 & 34,6 & $35,2^{A B}$ \\
\hline$u$ & 29,9 & 33,6 & 32,0 & 33,9 & $32,4^{C}$ \\
\hline SA & 31,0 & 32,3 & 33,0 & 36,1 & $33,1^{A B}$ \\
\hline$U+S A$ & 34,5 & 35,8 & 34,2 & 37,0 & $35,4^{\mathrm{ABC}}$ \\
\hline U+SPS & 32,6 & 34,6 & 35,5 & 36,7 & $34,8^{\mathrm{ABC}}$ \\
\hline $\mathrm{U}+\mathrm{KCl}$ & 31,2 & 33,9 & 32,8 & 33,4 & $32,8^{B C}$ \\
\hline $\mathrm{Sim}^{3}$ & 33,4 & 35,1 & 37,8 & 36,4 & $35,7^{\mathrm{A}}$ \\
\hline Média & $32,4^{b}$ & $34,6^{a}$ & $34,4^{\mathrm{a}}$ & $35,4^{\mathrm{a}}$ & \\
\hline
\end{tabular}

${ }^{1}$ Médias seguidas por mesma letra, minúscula na linha e maiúscula na coluna, não diferem entre si pelo teste de Tukey $(p>0,05)$

${ }^{2}$ Período compreendido entre os dias 14 de julho de 2003 e 20 de setembro de 2003

${ }^{3}$ Médias das amostras de pastejos simulados dos seis tratamentos

Quanto aos teores de FDA, o tratamento $U$ foi inferior aos demais (Tabela 19), caracterizando uma forragem de $\mathrm{VN}$ superior àquela observada no tratamento SA e nas amostras de pastejo simulado. No entanto essa diferença deve ser conseqüência do coeficiente de variação das amostras coletadas, principalmente na primeira quinzena de coleta. Esperava-se que plantas de elevado acúmulo de forragem, como foram as dos tratamentos U, SA e U+SA (Tabela 8), acumulassem mais componentes estruturais, devido a maior 
quantidade de hastes no dossel, necessárias na manutenção da sustentação da planta, em especial aquelas expostas a um longo período de vedação.

Os valores observados na Tabela 19 estão de acordo com os de Bueno et al. (2000), onde a $B$. brizantha diferida no final de março e utilizada em julho apresentou valores de FDA ao redor de 33\%; e inferiores aos observados por Gomes (2003), que seguindo a mesma estratégia de vedação e utilização encontrou, também para $B$. brizantha, teores de FDA de $44,5 \%$, indicando que os valores apresentados na Tabela 19 são de forragem de melhor VN.

Tabela 20. Teor de lignina da forragem ofertada nos diferentes tratamentos e da média dos pastejos simulados ao longo do período de pastejo

\begin{tabular}{|c|c|c|c|c|c|}
\hline \multirow{2}{*}{ Tratamento } & \multicolumn{4}{|c|}{ 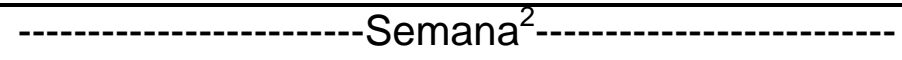 } & \multirow{2}{*}{ Média $^{1}$} \\
\hline & 2 & 4 & 6 & 8 & \\
\hline & ---------- & ------ & $\%$ da MS & --- & ----- \\
\hline Test. & $5,47^{A b}$ & $6,11^{\mathrm{Ab}}$ & $7,72^{\mathrm{Aa}}$ & $7,19^{\mathrm{ABa}}$ & $6,62^{\mathrm{A}}$ \\
\hline U & $5,34^{\mathrm{Ab}}$ & $5,89^{\mathrm{ABb}}$ & $6,96^{\mathrm{Aa}}$ & $6,93^{\mathrm{ABa}}$ & $6,28^{\mathrm{A}}$ \\
\hline SA & $5,30^{\mathrm{Ab}}$ & $5,63^{\mathrm{ABb}}$ & $7,15^{\mathrm{Aa}}$ & $7,57^{\mathrm{Aa}}$ & $6,41^{A}$ \\
\hline$U+S A$ & $5,67^{A b}$ & $5,89^{A B b}$ & $7,22^{\mathrm{Aa}}$ & $7,66^{\mathrm{Aa}}$ & $6,61^{A}$ \\
\hline U+SPS & $5,61^{A b}$ & $5,99^{A B b}$ & $7,45^{\mathrm{Aa}}$ & $7,59^{\mathrm{Aa}}$ & $6,66^{A}$ \\
\hline $\mathrm{U}+\mathrm{KCl}$ & $5,31^{A b}$ & $5,75^{\mathrm{ABb}}$ & $6,92^{\mathrm{A}} \mathrm{a}$ & $7,02^{\mathrm{ABa}}$ & $6,25^{A}$ \\
\hline $\operatorname{Sim}^{3}$ & $4,70^{A b}$ & $5,01^{\mathrm{Bb}}$ & $5,52^{\mathrm{Bab}}$ & $6,21^{\mathrm{Ba}}$ & $5,36^{\mathrm{B}}$ \\
\hline Média & $5,34^{c}$ & $5,75^{b}$ & $6,99^{\mathrm{a}}$ & $7,17^{\mathrm{a}}$ & \\
\hline
\end{tabular}

${ }^{1}$ Valores seguidos por mesma letra, minúscula na linha e maiúscula na coluna, não diferem entre si pelo teste de Tukey $(p>0,05)$

${ }^{2}$ Período compreendido entre os dias 14 de julho de 2003 e 20 de setembro de 2003

${ }^{3}$ Médias das amostras de pastejos simulados dos seis tratamentos

Os teores FDA no decorrer do período de pastejo foram inferiores na primeira quinzena de pastejo (32,4\%), em comparação à media de 34,8\% nas semanas seguintes. Comportamento semelhante foi observado para os teores de lignina (Tabela 20), onde os maiores teores ocorreram na sexta e oitava 
semanas de pastejo, com valores médios de 7,08\%, e os menores na primeira (5,3\%), com valores intermediários na quarta semana de avaliação.

Não houve diferença entre os tratamentos para o teor de lignina na massa de forragem, sendo os valores semelhantes aos de Reis (2000) que determinou teores de lignina em $B$. brizantha com 110 dias de crescimento, da ordem de $6,5 \%$. Além disso, esse mesmo autor determinou que essa fração da parede celular cresce linearmente a uma taxa de $0,0215 \%$ da $M S$ ao dia $\left(R^{2}=0,91\right)$, explicando o aumento nos teores de lignina do decorrer do período, além de evidenciar a importância da idade da planta na sua DIVMS. Segundo Van Soest (1994) e Traxler et al. (1998), aumentos da fração lignina da parede celular resultam em interferências negativas na digestibilidade da mesma, sendo essa provavelmente uma das razões para o decréscimo da DIVMS ao longo do período de pastejo (Tabela 21).

Tabela 21. DIVMS da forragem ofertada nos diferentes tratamentos e da média dos pastejos simulados ao longo do período de pastejo

\begin{tabular}{|c|c|c|c|c|c|}
\hline \multirow{2}{*}{ Tratamento } & \multicolumn{4}{|c|}{ 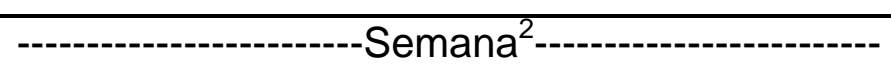 } & \multirow{2}{*}{ Média $^{1}$} \\
\hline & 2 & 4 & 6 & 8 & \\
\hline & . & . & o da M & $-\cdots$ & 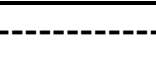 \\
\hline Test. & 54,6 & 49,0 & 46,6 & 45,7 & $49,0^{\mathrm{BC}}$ \\
\hline$u$ & 55,9 & 50,7 & 51,7 & 47,3 & $51,4^{\mathrm{AB}}$ \\
\hline SA & 54,4 & 51,5 & 49,3 & 42,8 & $49,5^{\mathrm{BC}}$ \\
\hline$U+S A$ & 51,4 & 49,3 & 45,7 & 39,5 & $46,5^{\mathrm{C}}$ \\
\hline U+SPS & 52,4 & 50,9 & 47,4 & 40,7 & $47,8^{\mathrm{BC}}$ \\
\hline $\mathrm{U}+\mathrm{KCl}$ & 53,5 & 51,9 & 48,9 & 46,6 & $50,2^{\mathrm{BC}}$ \\
\hline $\operatorname{Sim}^{3}$ & 58,0 & 56,9 & 52,7 & 50,1 & $54,4^{\mathrm{A}}$ \\
\hline Média & $54,3^{\mathrm{a}}$ & $51,5^{\mathrm{b}}$ & $48,9^{c}$ & $44,7^{d}$ & \\
\hline
\end{tabular}

${ }^{1}$ Valores seguidos pela mesma letra, minúscula na linha e maiúscula na coluna, não diferem entre si pelo teste de Tukey ( $p>0,05)$

${ }^{2}$ Período compreendido entre os dias 14 de julho de 2003 e 20 de setembro de 2003.

${ }^{3}$ Médias das amostras de pastejos simulados dos seis tratamentos 
Além do aumento do teor de lignina com o aumento da maturidade da pastagem, o processo de pastejo também provocaria o decréscimo da digestibilidade média da forragem, uma vez que as melhores partes da planta seriam consumidas no início desse período, restando as frações menos digestíveis para o final do mesmo. Essa situação é agravada quando o ritmo de crescimento da planta é lento, não proporcionando o aparecimento de tecidos novos na forragem, a ponto do material senescido ser a fração predominante do dossel forrageiro, como ocorreu no presente trabalho.

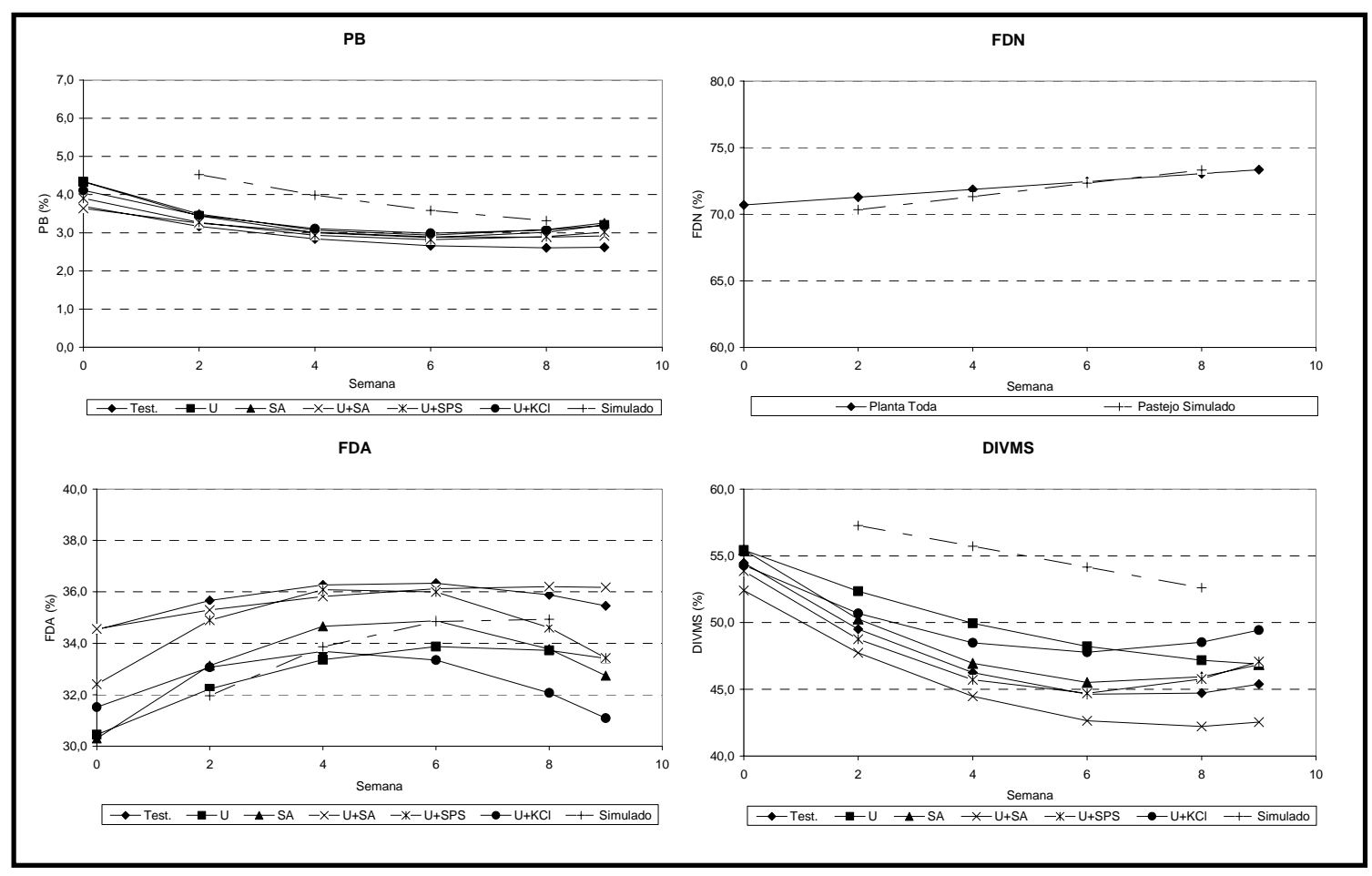

Período compreendido entre os dias 14 de julho de 2003 e 20 de setembro de 2003

Figura 20 - Composição química e digestibilidade da forragem ofertada nos diferentes tratamentos e da média dos pastejos simulados ao longo do período de pastejo

A DIVMS diferiu entre os tratamentos $U$ e $U+S A$, enquanto as amostras do pastejo simulado foram superiores às amostras de forragem em oferta dos 
tratamentos, exceto para U. Os valores apresentados na Tabela 21 estão de acordo com os obtidos por Leite et al. (1998), Bueno et al (2000), Gomes (2003), que obtiveram para $B$. brizantha coeficientes de digestibilidade de $54,8 \%, 52,5 \%$ e $49,15 \%$, respectivamente.

A superioridade do pastejo simulado em relação à forragem total nos tratamentos, com exceção do $U$, indica que o animal em pastejo seria capaz de coletar dieta de VN superior (Figura 20). A simulação de pastejo apresentou teores de DIVMS variando de 50,1\% a 58\% (Tabela 21) enquanto que o material ofertado apresentava teores de $44,7 \%$ e $54,3 \%$. Esses resultados são semelhantes aos de Euclides et al. (1992) e Camarão et al. (1994).

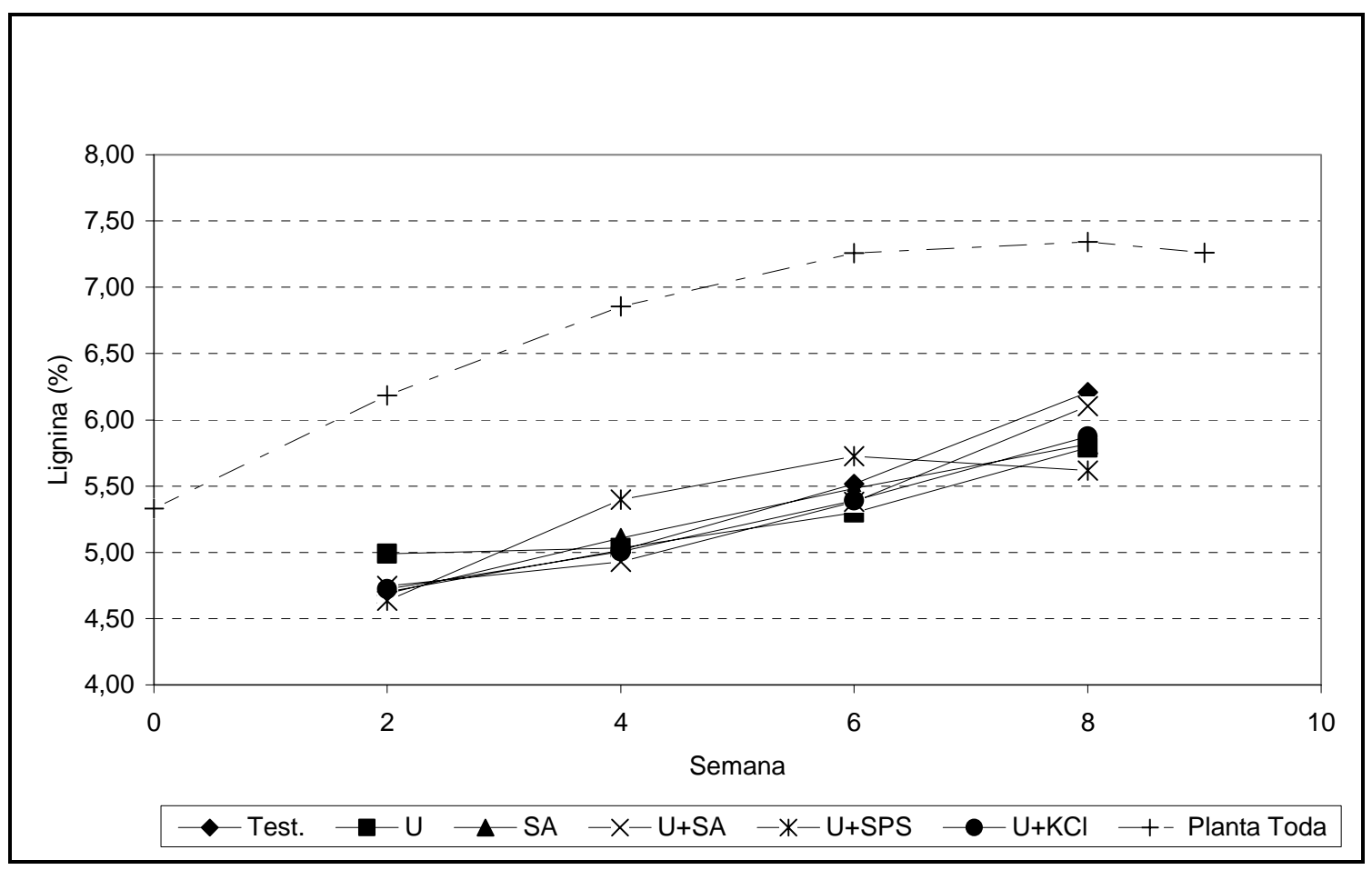

Período compreendido entre os dias 14 de julho de 2003 e 20 de setembro de 2003

Figura 21 - Teor de lignina da simulação de pastejo nos diferentes tratamentos e da média das massas de forragem ao longo do período de pastejo 
Os teores de lignina da forragem selecionada foram inferiores àqueles da forragem total em todos os tratamentos (Figura 21), suportando a idéia de que a DIVMS está inversamente relacionada com a presença desse componente da parede celular (Van Soest, 1994).

Tabela 22. Equações utilizadas para gerar as curvas de composição química e digestibilidade das amostras de forragem ofertada e pastejos simulados

\begin{tabular}{|c|c|c|c|}
\hline TRATAMENTO & VARIÁVEL & REGRESSÃO & $\mathrm{R}^{2}$ \\
\hline $\begin{array}{c}\text { TEST }^{1} \\
\mathrm{U}^{1} \\
\mathrm{SA}^{1} \\
\mathrm{U}+\mathrm{SA}^{1} \\
\mathrm{U}+\mathrm{SPS} \\
\mathrm{U}+\mathrm{KCl} \mathrm{C}^{1} \\
\text { SIMULADO }\end{array}$ & PB & $\begin{array}{l}0,5678-0,0382 x+0,002403 x^{2} \\
0,6372-0,0603 x+0,005071 x^{2} \\
0,6376-0,0568 x+0,004777 x^{2} \\
0,5611-0,0284 x+0,001972 x^{2} \\
0,5908-0,0456 x+0,003704 x^{2} \\
0,6138-0,0449 x+0,003631 x^{2} \\
5,1958-0,3688 x+0,016690 x^{2}\end{array}$ & $\begin{array}{l}0,70 \\
0,70 \\
0,70 \\
0,70 \\
0,70 \\
0,70 \\
0,80\end{array}$ \\
\hline $\begin{array}{l}\text { TEST } \\
U \\
\text { SA } \\
\text { U+SA } \\
\text { U+SPS } \\
\text { U+KCI } \\
\text { SIMULADO }\end{array}$ & FDA & $\begin{array}{l}34,5260+0,7021 x-0,066520 x^{2} \\
30,4429+1,0518 x-0,080150 x^{2} \\
30,3070+1,7431 x-0,163600 x^{2} \\
34,5651+0,4204 x-0,026850 x^{2} \\
32,4150+1,5633 x-0,161100 x^{2} \\
31,5203+1,0112 x-0,117700 x^{2} \\
29,1575+1,6307 x-0,113600 x^{2}\end{array}$ & $\begin{array}{l}0,54 \\
0,54 \\
0,54 \\
0,54 \\
0,54 \\
0,54 \\
0,69\end{array}$ \\
\hline $\begin{array}{c}\text { TEST } \\
U \\
\text { SA } \\
\text { U+SA } \\
\text { U+SPS } \\
\text { U+KCI } \\
\text { SIMULADO }\end{array}$ & DIVMS & $\begin{array}{l}54,4676-2,8928 x+0,209300 x^{2} \\
5,4449-1,7152 x+0,085090 x^{2} \\
55,4413-3,0556 x+0,233500 x^{2} \\
52,3999-2,6907 x+0,177300 x^{2} \\
53,8574-3,0635 x+0,256600 x^{2} \\
54,3080-2,1813 x+0,182200 x^{2} \\
58,8185-0,7766 x\end{array}$ & $\begin{array}{l}0,65 \\
0,65 \\
0,65 \\
0,65 \\
0,65 \\
0,65 \\
0,46\end{array}$ \\
\hline $\begin{array}{l}\text { PLANTA TODA }{ }^{1} \\
\text { SIMULADO }\end{array}$ & FDN & $\begin{array}{l}1,8494+0,0018 x \\
69,3509+0,4968 x\end{array}$ & $\begin{array}{l}0,25 \\
0,55\end{array}$ \\
\hline $\begin{array}{c}\text { TEST. } \\
\text { U } \\
\text { SA } \\
\text { U+SA } \\
\text { U+SPS } \\
\text { U+KCl } \\
\text { PLANTA TODA }\end{array}$ & Lignina & $\begin{array}{l}4,5750+0,0164 x+0,023440 x^{2} \\
5,1706-0,1463 x+0,027970 x^{2} \\
4,2322+0,2391 x-0,005150 x^{2} \\
4,8306-0,1098 x+0,033590 x^{2} \\
3,4344+0,7089 x-0,054530 x^{2} \\
4,5431+0,0651 x+0,012660 x^{2} \\
0,7268+0,0372 x-0,002480 x^{2}\end{array}$ & $\begin{array}{l}0,81 \\
0,81 \\
0,81 \\
0,81 \\
0,81 \\
0,81 \\
0,82\end{array}$ \\
\hline
\end{tabular}

\footnotetext{
${ }^{1}$ Dados transformados para $\log _{10}$
} 
Por outro lado, os teores de PB no pastejo simulado foram superiores apenas aos da forragem total da testemunha (Figura 20, Tabela 17), ao contrário do determinado por Euclides et al. (1992) e Camarão et al. (1994), onde a dieta selecionada foi consistentemente superior à forragem disponível. Isso é explicado em parte pela grande oferta de forragem aos animais nesses experimentos, normalmente acima dos $9 \%$, enquanto que no presente trabalho a oferta de forragem média foi estimada ao redor de 4,1\%, limitando assim a capacidade de seleção do animal em pastejo. Além disso, no trabalho de Camarão et al. (1994), o teor médio de PB na forragem total durante o inverno foi de $6 \%$, favorecendo a seleção do animal em pastejo, uma vez que a proporção de tecidos com maior teor de PB deveria ser mais abundante.

\subsection{Período de Rebrota}

Não foram detectados efeitos de tratamento e de interação com épocas de avaliação para as MF total, MSV e MS digestível (Tabela 23). Dessa forma, pode-se inferir que as estratégias de adubação no momento da vedação das parcelas não implicaram em efeito residual sobre a pastagem no início do período das águas. Deve-se atentar para o fato da rebrota ter sido avaliada em apenas duas datas, sendo a segunda 47 dias após a saída dos animais. Provavelmente esse período tenha sido insuficiente para a expressão de efeitos residuais da adubação nitrogenada.

Martello et al (2000), trabalhando com capim elefante, reportaram o efeito de doses crescentes de adubação nitrogenada (60, 120, 180 e $240 \mathrm{~kg} \mathrm{~N}^{-h^{-1}}$ ) aplicadas em março em relação às produções de forragem e eficiências do uso

do N. O experimento, iniciado em março com corte de uniformização e adubação, teve em novembro, após o terceiro corte, mais uma adubação nitrogenada de $60 \mathrm{~kg} \mathrm{~N}$ ha $^{-1}$ para todos os tratamentos. Os três primeiros cortes foram respectivamente nas três datas: 16/05/97, 18/09/97, 20/11/97, e os dois 
cortes restantes e posterior à adubação suplementar foram em 22/01/98 e 07/03/98. Os tratamentos cujas adubações em março foram de $120 \mathrm{~kg} \mathrm{~N} \mathrm{ha}^{-1}$ ou superiores, resultaram em maiores produções no quarto corte, quando comparado ao tratamento adubado com $60 \mathrm{~kg} \mathrm{~N} \cdot \mathrm{ha}^{-1} \mathrm{em}$ ambas as ocasiões, demonstrando o efeito residual das adubações superiores a $120 \mathrm{~kg} \mathrm{~N} \cdot \mathrm{ha}^{-1}$.

Tabela 23. Parâmetros produtivos médios dos seis tratamentos testados ao longo do período de rebrota

\begin{tabular}{ccccc}
\hline $\mathrm{Dia}^{2}$ & \multicolumn{3}{c}{ Massa de Forragem $^{1}$} & $\begin{array}{c}\text { Recuperação } \\
\text { Aparente }\end{array}$ \\
\hline & MS & MSV & PMS Dig & \\
\hline $\mathrm{R}^{3}$ & $2683,1^{\mathrm{B}}$ & $0,0^{\mathrm{C}}$ & $1218,80^{\mathrm{C}}$ & $8,3 \%^{\mathrm{B}}$ \\
34 & $2956,8^{\mathrm{AB}}$ & $1035,02^{\mathrm{B}}$ & $1692,03^{\mathrm{B}}$ & $13,5 \%{ }^{\mathrm{AB}}$ \\
47 & $3523,2^{\mathrm{A}}$ & $1684,29^{\mathrm{A}}$ & $2227,71^{\mathrm{A}}$ & $28,9 \%^{\mathrm{A}}$
\end{tabular}

\footnotetext{
${ }^{1}$ Médias seguidas por mesma letra, maiúscula na coluna, não diferem entre si pelo teste de Tukey $(p>0,05)$

${ }^{2}$ Período compreendido entre os dias 20 de setembro de 2003 e 07 de novembro de 2003

${ }^{3}$ Resíduo do período de pastejo ao final da 9a semana, no dia 20 de setembro de 2003
}

Os dados apresentados na Tabela 23 ilustram acréscimos na massa de forragem total, de forragem digestível e principalmente de forragem verde (Figura 22), resultado das condições ambientais mais propícias ao desenvolvimento da planta, como aumentos na temperatura e luminosidade, além de melhorias no status hídrico do solo, como pode ser visto na Figura 8.

Houve também aumento da recuperação aparente do $N$ aplicado no decorrer do período de rebrota. O cálculo da recuperação do $\mathrm{N}$ baseia-se nos dados de massa de forragem e teor de $\mathrm{N}$ da planta, o que permite concluir que se a recuperação do $\mathrm{N}$ foi significativa, os tratamentos adubados acumularam nitrogênio sem resposta na produção de forragem. O teor de PB da testemunha foi inferior aos demais tratamentos, com exceção do $\mathrm{U}+\mathrm{KCl}$, justificando assim os efeitos da recuperação aparente (Tabela 24). 


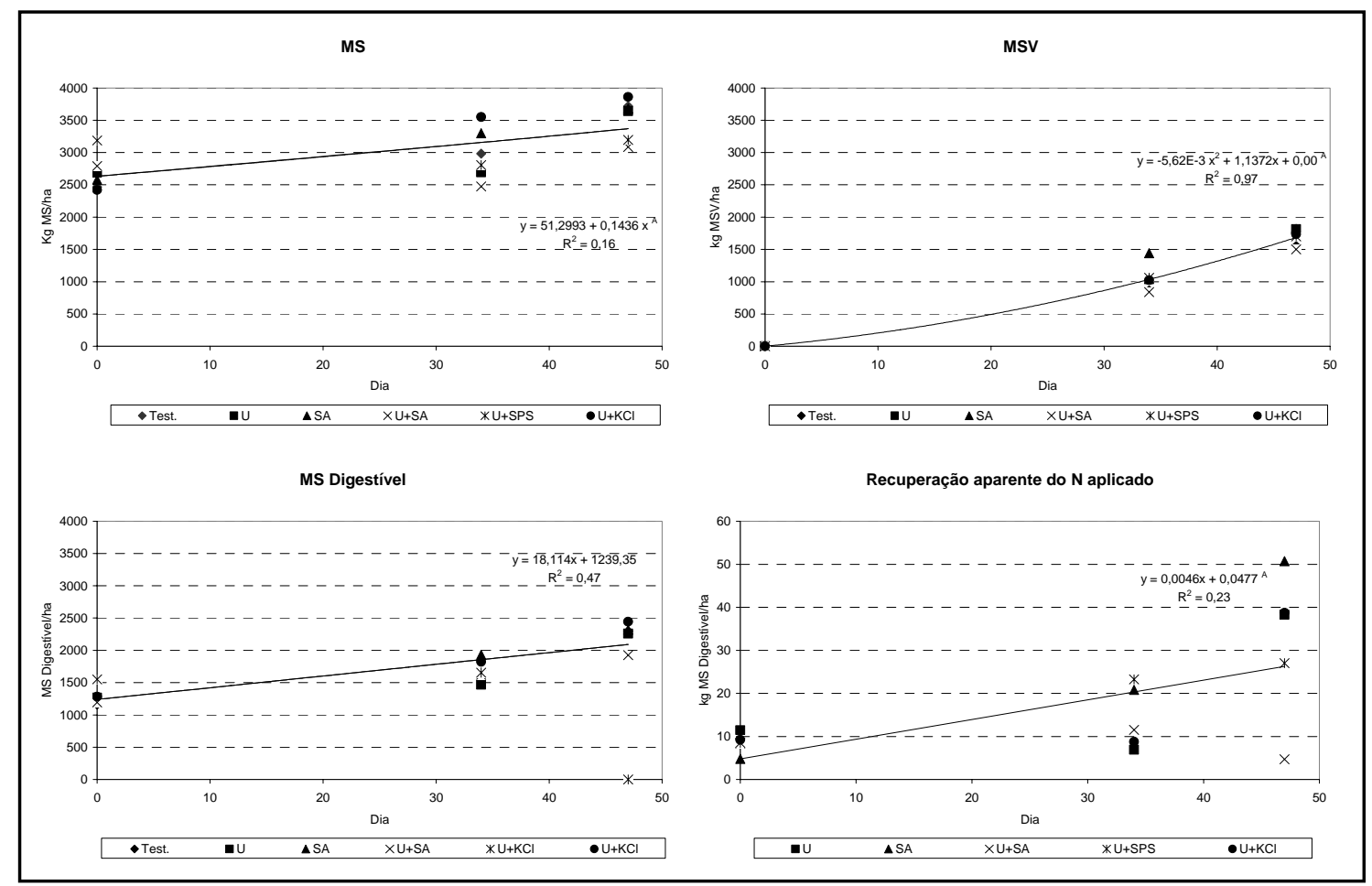

Período compreendido entre 20 de setembro de 2003 e 07 de novembro de 2003

${ }^{A}$ Dados transformados para raiz quadrada

Figura 22 - Massa de forragem total, forragem verde, forragem digestível e recuperação aparente do nitrogênio aplicado no decorrer do período de rebrota

Tabela 24. Teor de proteína bruta nos diferentes tratamentos ao longo do período de rebrota

\begin{tabular}{|c|c|c|c|c|c|c|c|}
\hline $\mathrm{Dia}^{2}$ & Test. & $\mathrm{U}$ & SA & $\mathrm{U}+\mathrm{SA}$ & U+SPS & $\mathrm{U}+\mathrm{KCl}$ & Média $^{1}$ \\
\hline & \multicolumn{7}{|c|}{------------------------------------\% da MS } \\
\hline $\mathrm{R} 2^{3}$ & 2,67 & 3,27 & 3,32 & 2,99 & 3,02 & 3,23 & $3,08^{B}$ \\
\hline 34 & 4,80 & 5,28 & 6,38 & 6,06 & 6,01 & 4,78 & $5,52^{A}$ \\
\hline 47 & 4,71 & 6,33 & 6,34 & 5,93 & 6,05 & 6,07 & $5,87^{A}$ \\
\hline Média & $3,92^{b}$ & $4,78^{a}$ & $5,12^{\mathrm{a}}$ & $4,75^{\mathrm{a}}$ & $4,79^{a}$ & $4,54^{a b}$ & \\
\hline
\end{tabular}

${ }^{1}$ Médias seguidas por mesma letra, minúscula na linha e maiúscula na coluna, não diferem entre si pelo teste de Tukey $(p>0,05)$

${ }^{2}$ Período compreendido entre os dias 20 de setembro de 2003 e 07 de novembro de 2003

${ }^{3}$ Resíduo do período de pastejo ao final da 9aㅗ semana, no dia 20 de setembro de 2003 
Dessa forma, apesar da similaridade de respostas de produção de forragem entre os tratamentos durante o período de rebrota, houve um efeito residual da adubação nitrogenada, sendo este evidenciado pelas diferenças nos teores de PB. No entanto, não houve diferenças entre as fontes de $\mathrm{N}$ e associações de fertilizantes, sendo esses tratamentos semelhantes entre si, tanto para produção de forragem quanto para os teores de PB. 


\section{CONCLUSÕES}

Apesar da superioridade dos valores médios do SA para a massa de forragem total, forragem verde, lâminas de folhas verdes, forragem digestível e recuperação aparente do $\mathrm{N}$, principalmente em relação a $\mathrm{U}+\mathrm{KCl}, \mathrm{U}+\mathrm{SPS}$ e testemunha, todas as diferenças foram nulas aos 104 dias de crescimento, e no decorrer do período de pastejo para os parâmetros produtivos e de pastejo simulado.

As máximas produções de MS, MSV e LFV ocorreram, respectivamente, aos 77, 63 e 63 dias; aos 421, 328 e 429 GD e às 3855, 2709 e 3033 UF, respectivamente. O uso de GD e UF na avaliação do acúmulo de forragem ao longo do período de crescimento não apresentaram vantagens em relação à avaliação diária, sendo o provável motivo a presença de déficit hídrico no solo.

As tendências de redução da massa de forragem nos tratamentos de crescimento mais acelerado como o $S A, U$ e $U+S A$ indicam que a adubação nitrogenada de pastagens diferidas deve ser empregada para produção de forragem destinada a primeira metade das "secas". No caso de pastagens

destinadas ao final das "secas" recomenda-se a diminuição da dose de nitrogênio utilizada, ou até eliminação da adubação.

As combinações de uréia com cloretos e sulfatos representados pelo $\mathrm{KCl}$, SA e sulfato de cálcio, constituinte do SPS, não beneficiaram a produção e recuperação do $\mathrm{N}$. Estudos que objetivam a aplicação de associações de fertilizantes devem ter controle sobre a uniformidade da distribuição, por essa representar fonte de variação desconhecida. 
A avaliação da pastagem diferida durante o pastejo deve ser baseada na densidade volumétrica da forragem verde, e na MF total com ressalvas, principalmente na presença de hastes lignificadas. A altura do dossel apresentou sérias restrições para essa avaliação.

Áreas a serem diferidas com o uso de fertilizantes podem acumular forragem de $\mathrm{VN}$ superior se a forragem for pastejada mais intensivamente antes do período de vedação. O menor ritmo de crescimento da planta, resultado de um menor IAF remanescente, seria compensado pelo uso do nitrogênio e aumento do período de diferimento. Nessa condição, o acumulo de folhas poderia ser mais representativo que de hastes.

O VN da forragem baseado nos teores de NDT decresce com o decorrer do período de pastejo, e o melhor aproveitamento desse atributo poderia ser feito através do aumento da oferta de forragem.

A oferta de forragem ao redor de $4 \%$ não permitiu ao animal em pastejo melhorar, através da seleção do material ingerido, os teores de PB da forragem ofertada em sua dieta. Por outro lado, a DIVMS média da forragem selecionada foi superior à da forragem em oferta, enquanto que o teor de lignina, foi inferior nas amostras de pastejo simulado. As frações FDN e FDA aumentaram com o período de pastejo, possivelmente reduzindo o consumo, seja pelo $\mathrm{VN}$ da forragem ou mudanças no dossel da planta. Desse modo, aumentos na oferta de forragem ao animal em pastejo poderiam talvez compensar a perda de VN da planta durante o pastejo.

O efeito residual das adubações nitrogenadas não foi evidenciado através do acúmulo de forragem, porém houve efeito no aumento dos teores de proteína bruta. 


\section{REFERÊNCIAS BIBLIOGRÁFICAS}

ALMEIDA, E.X.; SETELICH, E.A.; MARASCHIN, G.E. Oferta de forragem e variáveis morfogênicas em capim elefante anão cv. Mott. In: REUNIÃO ANUAL DA SOCIEDADE BRASILEIRA DE ZOOTECNIA, 34., Juiz de Fora, 1997. Anais. Juiz de Fora: SBZ, 1997, p.240-242.

ANDRADE, C.A.; FONSECA, D.M.; GOMIDE, J.A.; et al. Produtividade e valor nutritivo do capim-elefante cv. Napier sob doses crescentes de nitrogênio e potássio. Revista Brasileira de Zootecnia, v. 29, n. 6, p. 1589-1595, 2000.

ANDRADE, F.M.E. Produção de forragem e valor alimentício do capim Marandu submetidos a regime de lotação continua por bovinos de corte. Piracicaba, 2004. 141p. Dissertação (Mestrado) - Escola Superior de Agricultura "Luiz de Queiroz", Universidade de São Paulo.

ANJOS, J.T.; TEDESCO, M.J. Perdas de nitrogênio, por volatilização de amônia, proveniente da uréia aplicada em solos cultivados. In: CONGRESSO BRASILEIRO DE CIÊNCIA DO SOLO, 14, Santa Maria, 1973. Anais. Santa Maria: Sociedade Brasileira de Ciência do Solo, 1973, p232-341.

ARAH, J. R. M.; SMITH, K. A.; CRICHTON, J.I.; LI, H.S. Nitrous oxide production and denitrification in Scottish arable soils. Journal of Soil Science, v.42, n.3, p.351-367, 1991. 
BALSALOBRE, M.A.A. Valor alimentar do capim Tanzânia irrigado. Piracicaba, 2002. 113p. Tese (Doutorado) - Escola Superior de Agricultura "Luiz de Queiroz", Universidade de São Paulo.

BALSALOBRE, M.A.A.; SANTOS, P.M.; BARROS, A.L.M. Inovações tecnológicas, investimentos financeiros e gestão de sistema de produção animal em pastagens. In: SIMPOSIO SOBRE MANEJO DE PASTAGEM, 19, Piracicaba, 2002. Anais. Piracicaba: FEALQ, 2002, p.1-30.

BALSALOBRE, M.A.A.; SANTOS, P.M.; MAYA, F.L.A.; et al. Pastagens irrigadas. In: SIMPOSIO SOBRE MANEJO DE PASTAGEM, 20, Piracicaba, 2003. Anais. Piracicaba: FEALQ, 2003, p.265-296.

BARCELLOS, C.F.; ANDRADE, I.F. Seleção da dieta por bovinos em pastagens de Capim-Andropongon sob difrentes lotações. Revista da Sociedade Brasileira de Zootecnia, v.22, n.4, p.513-525, 1993.

BARIONI, L.G. Modelagem dinâmica e otimização metaheurística para apoio à tomada de decisões na recria e engorda de bovinos de corte. Piracicaba, 2002. 100p. Tese (Doutorado) - Escola Superior de Agricultura "Luiz de Queiroz", Universidade de São Paulo.

BOIN, C. Caracterização das etapas de cria, recria e engorda face à produção estacional das pastagens e as forrageiras disponíveis. In: CURSO SOBRE MANEJO DE PASTAGEM, 1, Nova Odessa, 1985. Anais. Nova Odessa: Instituto de Zootecnia, 1985, p.1-32.

BUENO, M.F.; MATTOS, H.B.; COSTA M.N.X.; et al. Épocas de vedação e de uso no capim Marandu I. Produção de matéria seca e valor nutritivo. Boletim de Indústria Animal, v.57, n.1, p.1-9, 2000. 
CAMARÃO, A.P.; BATISTA, H.A.M.; LOURENÇO JÚNIOR, J.B.; et al. Composição botânica e valor nutritivo da forragem disponível e dieta selecionada por bubalinos em pastagens de Brachiaria humidicola. Pesquisa Agropecuária Brasileira, v.29, n.3, p.491-501, 1994.

CANAL DO TEMPO. http://br.weather.com/ (20 abril 2004).

CANTARELLA, H. Adubação nitrogenada em sistema de cana crua. Revista Stab, v.16, n.4, p.21-22, 1998.

CARNEVALLI, C.A. Dinâmica da rebrotação de pastos de capim Mombaça submetidos a regimes de desfolhação intermitente. Piracicaba, 2003. 136 p. Tese (Doutorado) - Escola Superior de Agricultura "Luiz de Queiroz", Universidade de São Paulo.

CHACON, E.; STOBBS, T.H. Influence of progressive defoliation of a grass sward on the eating behaviour of cattle. Australian Journal of Agricultural Research, v.27, p.709-727, 1976.

CORSI, M. Espécies forrageiras para pastagens. In. SIMPÓSIO SOBRE O MANEJO DA PASTAGEM, 3. Piracicaba, 1976. Anais. Piracicaba: ESALQ, 1976, p.5-36.

CORSI, M.; MARTHA JUNIOR, G.B.; BALSALOBRE, M.A.A.; et al. Tendências e perspectivas da produção de bovinos sob pastejo. In: SIMPOSIO SOBRE MANEJO DE PASTAGEM, 17, Piracicaba, 2000. Anais. Piracicaba: FEALQ, 2000, p.3-70.

CORSI, M.; MARTHA JÚNIOR. Manutenção da fertilidade do solo em sistemas intensivos de pastejo rotacionado. In: SIMPÓSIO SOBRE MANEJO DA PASTAGEM, 14, Piracicaba, 1997. Anais. Piracicaba: FEALQ, 1997. p.161193. 
CORSI, M.; MENEZES, M.J.T.; GOULART, R.C.D. Manejo do pastejo para altas taxas de lotação. In: SIMPÓSIO GOIANO SOBRE MANEJO E NUTRIÇÃO DE BOVINOS DE CORTE, 6, Goiânia, 2004. Anais. CBNA: Goiânia, 2004. p. 299-321.

CORSI, M.; NASCIMENTO JUNIOR, D. Princípios de fisiologia e morfologia de plantas forrageiras aplicados no manejo das pastagens. In: PEIXOTO A.M.; MOURA, J.C.; FARIA V.P. (Ed.). Pastagens, fundamentos da exploração racional. Piracicaba: FEALQ, 1994, p. 15-48.

CORSI, M.; NUSSIO, L.G. Manejo do capim elefante: correção e adubação do solo. In: SIMPOSIO SOBRE MANEJO DE PASTAGEM, 10, Piracicaba, 1994. Anais. Piracicaba: FEALQ, p.87-116.

COSTA, F.P. Pecuária de corte no Brasil Central: o produtor, os recursos produtivos e o manejo das pastagens. Campo Grande: EMBRAPA, 2000. 34p. (Circular Técnica)

COSTA, M.N.X. Influência de épocas e doses de adubação nitrogenada na produção estacional de dois capins. Piracicaba, 1999. 67p. Dissertação (Mestrado) - Escola Superior de Agricultura "Luiz de Queiroz", Universidade de São Paulo.

COSTA, N.L.; OLIVEIRA, J.R. Épocas de vedação e utilização de Andropogon guayanus cv. Planaltina em Rondônia. Rondônia: Empresa Brasileira de Pesquisa Agropecuária (EMBRAPA)/CPAF Rondônia, 1992. 4p. (Comunicado Técnico, 103.)

COSTA, N.L.; OLIVEIRA, J.R.C.; PAULINO, V.T. Efeito do diferimento sobre o rendimento de forragem e composição química de Brachiaria brizantha cv. Marandu em Rondônia. Revista Brasileira de Zootecnia, v.22, p.495-501, 1993. 
DEPARTAMENTO DE CIENCIAS EXATAS, ESALQ - USP. Base de dados da estação convencional. http://www.lce.esalq.usp.br/postocon.html (20 abril 2004).

EMBRAPA HORTALIÇAS. http://www.cnph.embrapa.br/ (20 abril 2004).

ERNST, J.W.; MASSEY, H.F. The effects of several factors on volatilization of ammonia formed from urea, in the soil. Soil Science Society Proceedings. v. 24, n.2, p.87-90, 1960.

EUCLIDES, V.P.B.; QUEIROZ, H.P. Manejo de pastagens para a produção e feno-em-pé. http://www.cnpgc.embrapa.br/eventos/2000/12encontro/ apostila.html (30 maio 2000).

EUCLIDES, V.P.B.; MACEDO, M.C.M.; OLIVEIRA, M.P. Avaliação de diferentes métodos de amostragem (para estimar o valor nutritivo de forragens) sob pastejo. Revista da Sociedade Brasileira de Zootecnia. v.21, n.4, p.691702, 1992.

EUCLIDES, V.P.B.; VALLE, C.B.; SILVA, J.M.; VIEIRA, A. Avaliação de forrageiras tropicais manejadas para a produção de feno em pé. Pesquisa Agropecuária Brasileira, v.25, n.1, p. 63-68, 1990.

EUCLIDES, V.P.B.; EUCLIDES FILHO, K; ARRUDA, Z.J.; FIGUEIREDO, G.R. Desempenho de novilhos em pastagens de Brachiaria decumbens submetidos a diferentes regimes alimentares. Revista Brasileira de Zootecnia. v.27, n.2, p.246-254, 1998.

EUCLIDES, V.P.B.; THIAGO, L.R.L.S.; MACEDO, M.C.M.; OLIVEIRA, M.P. Consumo voluntário de forragem de três cultivares de Panicum maximum sob pastejo. Revista Brasileira de Zootecnia, v.28, n.6, p.1177-1185, 1999. 
EUCLIDES, V.P.B.; EUCLIDES FILHO, K; COSTA, F.P.; FIGUEIREDO, G.R. Desempenho de novilhos F1s Angus-Nelore em pastagens de Brachiaria decumbens submetidos a diferentes regimes alimentares. Revista Brasileira de Zootecnia. v.30, n.2, p.470-481, 2001.

FACULDADE DE ENGENHARIA DE ILHA SOLTEIRA, UNESP. Dados agrometeorológicos. http://www.agr.feis.unesp.br/clima.php (20 abril 2004).

FARIA, V.P.; PEDREIRA, C.G.S.; SANTOS F.A.P. Evolução do uso de pastagens para bovinos. In: SIMPÓSIO SOBRE MANEJO DA PASTAGEM, 13, Piracicaba, 1996. Anais. Piracicaba: FEALQ, p.1-14.

FILGUEIRAS, E.P.; BORGES, A.L.C.C.; RODRIGUEZ, N.M.; et al. Efeito do período de vedação sobre a produção e qualidade da Brachiaria decumbens Stapf: I - matéria seca e proteína bruta. Arquivo Brasileiro de Medicina Veterinária e Zootecnia, v.49, n.5, p. 587-601, 1997.

FOOD AND AGRICULTURE ORGANIZATION OF THE UNITED NATIONS. FAO Statistical Databases. http://apps.fao.org/default.jsp (26 maio 2004).

FOX, D.G.; SNIFFEN, C.J.; O'CONNOR, J.D.; et al. A net carbohydrate and protein system for evaluating cattle diets: III. Cattle requirements and diet adequacy. Journal of Animal Science, v.70, p.3578-3596, 1992.

GHELFI FILHO, H. Efeito da irrigação sobre a produtividade do capim elefante (Pennisetum purpureum schum.) variedade napier. Piracicaba, 1972. 77p. Tese (Doutorado) - Escola Superior de Agricultura "Luiz de Queiroz", Universidade de São Paulo.

GOMES, V.M. Disponibilidade e valor nutritivo de braquiária vedada para uso na região semi-árida de Minas Gerais. Lavras, 2003. 99p. Dissertação (Mestrado) - Universidade Federal de Lavras. 
INSTITUTO BRASILEIRO DE ECONOMIA E ESTATÍSTICA. Sistema IBGE de recuperação automática - SIDRA. http://www.ibge.gov.br (26 maio 2004).

INSTITUTO BRASILEIRO DO MEIO AMBIENTE E DOS RECURSOS NATURAIS RENOVÁVEIS. Áreas desmatadas nos períodos de 1996 a 2001. http://www.ibama.gov.br/desmata/index.htm (10 agosto 2004).

INSTITUTO DE ECONOMIA AGRÍCOLA. Preços de terra: comparação entre os Preços de Terra de Novembro de 2002 e de Novembro de 2003. http://www.iea.sp.gov.br/out/iterra.htm (26 maio 2004a).

INSTITUTO DE ECONOMIA AGRÍCOLA. Levantamento Subjetiva - Estado de São Paulo. http://www.iea.sp.gov.br/out/ibcoiea.htm (10 agosto 2004b).

JANK, L. Melhoramento e seleção de variedades de Panicum maximum. In: SIMPÓSIO SOBRE MANEJO DA PASTAGEM, 12, Piracicaba, 1995. Anais. Piracicaba: FEALQ, 1995. p.22-58.

JANK, I.; BATISTOTI, C.; FERREIRA, G.F.C.R. Herança da característica estolonífera em Panicum maximum. In: REUNIÃO ANUAL DA SOCIEDADE BRASILEIRA DE ZOOTECNIA, 31, Maringá, 1994. Anais. Maringá: SBZ, 1994. p.304-307.

KIEHL, J.C. Distribuição e retenção da amônia no solo após aplicação de uréia. Revista Brasileira de Ciência do Solo, v.13, p-75-80, 1989.

KORTE, C.J.; WATKIN, B.R., HARRIS, W. Use of residual leaf area index and light interception as criteria for spring-grazing management of a ryegrassdominant pasture. New Zealand Journal of Agricultural Research, v.25, p.309-319, 1982. 
LEITE, G.G.; COSTA, N.L.; GOMES, A.C. Efeito da época de diferimento sobre a produção e qualidade da forragem de gramíneas na região dos Cerrados do Brasil. Pasturas Tropicales, v.20, p. 15-22, 1998.

LEITE, G.G.; EUCLIDES, V.P.B.Utilização de pastagens de Brachiaria ssp. In: SIMPOSIO SOBRE MANEJO DE PASTAGEM, 11, Piracicaba, 1994. Anais. Piracicaba: Fealq, p.267-297.

LITTELL, R.C.; MILLIKEN, G.A.; STROUP, W.W; WOLFINGER, R.D. SAS ${ }^{\circledR}$ System for Mixed Model. Cary, NC: SAS Institute, 1996. 633p.

LOURENÇO, A.J.; LASCANO, C. Efeito do pastejo seqüencial na composição botânica da forragem disponível e da dieta selecionada por bovinos em pastos de Andropogon gayanus kunth consorciado. Boletim de Indústria Animal, v.45, n.2, p.333-342, 1988.

LUZ, P.H.C. In: Câmara, G.M.S. (Ed.). Soja: Tecnologia da produção II. Piracicaba: ESALQ/LPV, 2000, p. 15-48.

t'MANNETJE, L. Effect of daylength and temperature on introduced legumes and grasses for the tropics and subtropics of coastal Australia. 2. Nconcentration, estimated digestibility and leafiness. Australian Journal of Experimental Agriculture and Animal Husbandry, v.15, p.256-263,1975.

t'MANNETJE, L.; PRITCHARD, A.F. Effect of daylength and temperature on introduced legumes and grasses for the tropics and subtropics of coastal Australia. 1. Dry matter production, tillering and leaf area. Australian Journal of Experimental Agriculture and Animal Husbandry, v.14, p.173$181,1974$.

MARTELLO, V.P. Doses de nitrogênio para maximização da produção do capim elefante cv. guaçú no período das secas. Boletim de Industria Animal, v.57, n.2, p.151-161, 2000. 
MARTHA JUNIOR, G.B. Balanço de ${ }^{15} \mathrm{~N}$ e perdas de amônia por volatilização em pastagem de capim elefante. Piracicaba, 1999. 75p. Dissertação (Mestrado) - Escola Superior de Agricultura "Luiz de Queiroz", Universidade de São Paulo.

MARTHA JUNIOR, G.B. Produção de forragem e transformações do nitrogênio do fertilizante em pastagem irrigada de capim Tanzânia. Piracicaba, 2003. 149p. Tese (Doutorado) - Escola Superior de Agricultura "Luiz de Queiroz", Universidade de São Paulo.

MARTHA JUNIOR, G.B.; BALSALOBRE, M.A.A. I Curso online de diferimento de pastagens e suplementação de bovinos de corte. Piracicaba: AGRIPOINT, 2001, 89p.

MARTHA JUNIOR, G.B.; CORSI, M. Diferimento de pastagens. Preços Agrícolas, v.15, n.173, p.15-18, 2001.

MARTHA JUNIOR, G.B.; VILELA, C. Pastagens no Cerrado: baixa produtividade pelo uso limitado de fertilizantes. Planaltina: EMBRAPA Cerrados, 2002. 32p. (Documentos, 50).

MATTOS, H.B.; PEDREIRA, J.V.S. Crescimento estacional de oito leguminosas forrageiras de clima tropical. Boletim de Indústria Animal, v.41, p.145-157, 1984.

MAYA, F.L.A. Produtividade e viabilidade econômica da recria e engorda de bovinos em pastagens adubadas intensivamente com e sem o uso da irrigação. Piracicaba, 2003. 83p. Dissertação (Mestrado) - Escola Superior de Agricultura "Luiz de Queiroz", Universidade de São Paulo. 
NABINGER, C.; PONTES, L.S. Morfogênese de plantas forrageiras e estrutura do pasto In. MATTOS, W.R.S. (Ed.). A produção animal na visão dos brasileiros. Piracicaba: FEALQ, 2001. p.755-771.

NATIONAL RESEARCH COUNCIL. Nutrient Requirements of Beef Cattle. 7 ed. Washington: National Academy Press, 1996. 242p.

NATIONAL RESEARCH COUNCIL. Nutrient Requirements of Dairy Cattle. 7 ed. Washington: National Academy Press, 2001. 450p.

OLIVEIRA, P.P.A. Manejo da calagem e da fertilização nitrogenada na recuperação de pastagens degradadas de Brachiaria sp. em solos arenosos. Piracicaba, 2001. 110p. Tese (Doutorado) - Escola Superior de Agricultura "Luiz de Queiroz", Universidade de São Paulo.

PAULINO, V.T.; BEISMAN, D.A.; FERRARI JUNIOR, E. Fontes de nitrogênio na recuperação de pastagens de Brachiaria decumbens durante o período da seca. Pasturas Tropicales, v.17, p.20-24, 1995.

PEDREIRA, J.V.S.; MATTOS, H.B. Crescimento estacional de vinte e cinco espécies de variedades de capins. Boletim da Industria Animal, v.38, n.2, p.117-143, 1981.

PEDREIRA, J.V.S.; MATTOS, H.B. Crescimento estacional de cultivares de capim elefante. Boletim de Indústria Animal, v.39, n.1, p.29-41, 1982.

PENATI, M. A. Estudo do desempenho animal e produção do capim Tanzânia (Panicum maximum, Jacq.) em um sistema rotacionado de pastejo sob irrigação em três níveis de resíduo pós pastejo. Piracicaba, 2002. Tese (Doutorado) - Escola Superior de Agricultura "Luiz de Queiroz", Universidade de São Paulo. 
PEREIRA, J.M.; NASCIMENTO JÚNIOR, D.; SANTANA, J.R.; et al. Teor de proteína bruta e digestibilidade in vitro da matéria seca da forragem disponível e da dieta selecionada por bovinos em pastagem de Brachiaria humidicola (Rendle) Schweickt, em monocultivo ou consorciado com leguminosas, submetida a diferentes taxas de lotação. Revista da Sociedade Brasileira de Zootecnia, v.21, n.1, p.104-117, 1992.

PIZARRO, E.A.; AMARAL, R.; VERA, R.R. Efecto de diferir la época de utilización em la producción y calidad de Panicum maximum. Pasturas Tropicales. v.15, n.1, p.23-29, 1993.

PIZARRO, E.A.; RAMOS, A.K.B.; CARVALHO, M.A. Efeito da época de diferimento em novo germoplasma de Brachiaria decumbens. Pasturas Tropicales, v.19, n.1, p. 16-20, 1996.

POPPI, D.P.; HUGHES, T.P.; L'HUILLIER, P.J. Intake of pasture by grazing ruminants. In: LIVESTOCK FEEDING ON PASTIURE. New Zealand Society of Animal Production, Occasional Symposium, 10, Hamilton, 1987. Anais. Hamilton: Lincoln College, p. 55-63.

PRESTON, T.R.; LENG, R.A. Matching ruminant production systems with available resources in the tropics and subtropics. Armidale, Australia: Penambul Books, 1987. 245p.

PRIMAVESI, O; PRIMAVESI, A.C.; CORRÊA, L.A.; et al. Eficiência agronômica de uréia aplicada superficialmente em pastagem de capim Coastcross. In:REUNIÃO ANUAL DA SOCIEDADE BRASILEIRA DE ZOOTECNIA, 38, Piracicaba, 2001a. Anais. Piracicaba:FEALQ, p.213-214. 
PRIMAVESI, O; PRIMAVESI, A.C.; CORRÊA, L.A.; et al. Variação semanal de nitrato no perfil do solo em pastagem de capim Coastcross intensamente adubada com nitrogênio, no período das chuvas. In:REUNIÃO ANUAL DA SOCIEDADE BRASILEIRA DE ZOOTECNIA, 38, Piracicaba, 2001b. Anais. Piracicaba:FEALQ, p.176-177.

PRIMAVESI, A.C; CORRÊA, L.A.; CANTARELLA, H.;PRIMAVESI, O.; FREITAS, A.R.; da SILVA, A.G. Eficiência nutricional de dois adubos nitrogenados aplicados a lanço em capim Coastcross (Cynodon dactylon $L$. Pears). In:REUNIÃO ANUAL DA SOCIEDADE BRASILEIRA DE ZOOTECNIA, 38, Piracicaba, 2001. Anais., Piracicaba:FEALQ, p. 178-179.

QUINN, I.R.; MOTT, G.O., BISSCHOFF, W.V.A. Fertilização de pastos de capim colonião e produção de carne com novilhos zebu. São Paulo: IBEC Research Institute, 1961. 40p. (Boletim, 24).

RAIJ, B. V. Fertilidade do solo e adubação. Piracicaba: Potafós, 1991. 343p.

REIS, R.A.; RODRIGUES, L.R.A. Valor nutritivo de plantas forrageiras. Jaboticabal. FUNEP, 1993. 26p.

REIS, R.A.; RODRIGUES, L.R.A.; PEREIRA, J.R.A. A suplementação como estratégia de manejo da pastagem. In: SIMPÓSIO SOBRE MANEJO DA PASTAGEM, 13, Piracicaba, 1996. Anais. Piracicaba: FEALQ, p.123-150.

REIS, S.T. Valor nutricional de gramíneas tropicais em diferentes idades de corte. Lavras, 2000. 99p. Dissertação (Mestrado) - Universidade Federal de Lavras.

RODRIGUES, M.B.; KIEHL, J.C. Volatilização de amônia após o emprego de uréia em diferentes doses e modos de aplicação. Revista Brasileira de Ciência do Solo, v.10, p.37-43, 1986. 
RODRIGUES, M.B.; KIEHL, J.C. Distribuição e nitrificação da amônia proveniente da uréia aplicada ao solo. Revista Brasileira de Ciência do Solo, v.16, p.403-408, 1992.

ROLIM, F.A. Estacionalidade de produção de forrageiras. In: PEIXOTO A.M.; MOURA, J.C.; FARIA V.P. (Ed.). Pastagens, fundamentos da exploração racional. Piracicaba: FEALQ, 1994, p. 533-566.

SILVA, D.J.; QUEIROZ, A.C. Análise de alimentos: métodos químicos e biológicos. 3.ed. Viçosa: UFV, 2002. 235p.

SILVA, S.C. Características morfo-fisiológicas e respostas funcionais de plantas forrageiras e animais submetidos a pastejo. Piracicaba, 2002. 487p. Tese (Livre Docência) - Escola Superior de Agricultura "Luiz de Queiroz", Universidade de São Paulo.

SILVEIRA NETO, S. Controle de insetos nocivos às pastagens de Brachiaria spp. In: SIMPOSIO SOBRE MANEJO DE PASTAGEM, 11, Piracicaba, 1994. Anais. Piracicaba: Fealq, p.73-98.

SNIFFEN, C.J.; O'CONNOR, J.D.;VAN SOEST, P.J.; et al. A net carbohydrate and protein system for evaluating cattle diets: II. Carbohydrate and protein availability. Journal of Animal Science, v.70, p.3562-3577, 1992.

SOTO, H.A.H. Modelo simples de estimativa de produção de forragem para colonião (Panicum maximum Jacq.) e pangola (a-24 Digitaria pentzii stent) usando parâmetros climáticos. Piracicaba, 1981. 58p. Dissertação (Mestrado) - Escola Superior de Agricultura "Luiz de Queiroz", Universidade de São Paulo.

STATISTICAL ANALYSIS SYSTEM. SAS: user's guide statistics: version 6. 10. ed. Cary, 1995. 956p. 
TEIXEIRA, E. I. Avaliação de características morfofisiológicas e nutricionais do capim Tobiatã (Panicum maximum cv. Tobiatã) sob sistema de pastejo rotacionado. Piracicaba, 1998. 87p. Dissertação (Mestrado) - Escola Superior de Agricultura "Luiz de Queiroz", Universidade de São Paulo.

TOMÉ JÚNIOR; J.B. Manual para interpretação de análise de solo. Guaíba: Agropecuária, 1997. 247p.

TONATO, F. Determinação de parâmetros produtivos e qualitativos de Cynodon spp. em função de variáveis climáticas. Piracicaba, 2003. 85p. Dissertação (Mestrado) - Escola Superior de Agricultura "Luiz de Queiroz", Universidade de São Paulo.

TOSI, P. Estabelecimento de parâmetros agronômicos para o manejo e eficiência de utilização de Panicum maximum Jacq. cv. Tanzânia-1 sob pastejo rotacionado. Piracicaba, 1999. 103p. Dissertação (Mestrado) Escola Superior de Agricultura "Luiz de Queiroz", Universidade de São Paulo.

TRAXLER, M.J.; FOX, D.J.; VAN SOEST, P.J.; et al. Predicting forage indigestible NDF from lignin concentration. Journal of Animal Science, v.76, p.1469-1480, 1998.

TRIVELIN, P.C.; LARA CABEZAS, W.A.R.; BOARETTO, A.E. Dinâmica do nitrogênio de fertilizantes fluidos no sistema solo-planta. In. VITTI, G.C.; BOARETTO, A.E. (Ed.). Fertilizantes fluidos. Piracicaba: Potafos, 1994. p.315-330.

VAN SOEST, P.J. Nutritional ecology of the ruminant. New York: Cornell University Press, 1994. 476p. 
VAN SOEST, P.J.; ROBERTSON, J.B.; LEWIS, B.A. Methods for dietary fiber, neutral detergent fiber, and nonstarch polysaccharides in relation to animal nutrition. Journal of Dairy Science, v.74, p.3583-3597, 1991.

VELDKAMP, E.; KELLER, M.; NUÑEZ, M. Effects of pasture management on $\mathrm{N}_{2} \mathrm{O}$ and $\mathrm{NO}$ emissions from soils in the humid tropics of Costa Rica. Global Biogeochemical Cycles, v.12, p.71-79, 1998.

VICENTE-CHANDLER, J. Intensive Management in Puerto Rico. Revista da Sociedade Brasileira de Zootecnia, v. 2, n. 2, p. 173-215, 1973.

VICENTE-CHANDLER, J; SILVA S.; FIGARELA J. The effect of nitrogen fertilization and frequency of cutting on the yield and composition of three tropical grasses. Agronomy Journal, v.51, p.202-206, 1959.

VICENTE-CHANDLER, J; SILVA S.; FIGARELA J. Effect of frequency of application on response of guinea grass to nitrogen fertilization. Journal of the University of Puerto Rico, v. 46, p.342-349, 1962.

VILLA NOVA, N. A.; PEDRO JUNIOR, M. J.; PEREIRA, A. R.; OMETTO, J. C. Estimativa de graus-dia acumulados acima de qualquer temperaturabase, em função das temperaturas máxima e mínima. São Paulo: Universidade de São Paulo - Instituto de Geografia, 1972. 8p. (Caderno de Ciências da Terra, 30).

VILLA NOVA, N.A.; CARRETEIRO, M.V.; SCARDUA, R. Um modelo para avaliação do crescimento de cana-de-açúcar (Sacharum spp.) em termos da ação combinada do fotoperíodo e da temperatura média do ar. In: CONGRESSO BRASILEIRO DE AGROMETEOROLOGIA, 2., Campinas, Anais. Sociedade Brasileira de Agrometeorologia/Instituto Agronômico de Campinas: Campinas, 1983. p. 31-48. 
VILLA NOVA, N.A.; BARIONI, L.G.; PEDREIRA, C.G.S.; PEREIRA, A.R. Modelo para previsão da produtividade do capim elefante em função de temperatura do ar, fotoperíodo e freqüência de desfolha. Revista Brasileira de Agrometeorologia. v. 7, n. 1, p. 75-79, 1999.

VITTI, A.C. Utilização pela cana-de-açúcar (cana planta) do nitrogênio da uréia $\left({ }^{15} \mathrm{~N}\right)$ e do mineralizado no solo em sistemas de manejo com e sem queima. Piracicaba, 1998. 93p. (Mestrado) - Centro de Energia Nuclear na Agricultura, Universidade de São Paulo.

VitTi, G. C., MALAVOltA, E., COUTINHO, E. L. M. Uso eficiente de fertilizantes nitrogenados e portadores de enxofre. In: SIMPÓSIO SOBRE FERTILIZANTE NA AGRICULTURA BRASILEIRA. Ilhéus, 1984. Anais. EMBRAPA: Ilhéus, 1984. p. 205-253.

VITTI, G.C.; TAVARES JUNIOR, J.E.; LUZ, P.H.C.; FAVARIN, J.L.; COSTA, M.C.G. Influência da mistura de sulfato de amônio com uréia sobre a volatilização de nitrogênio amoniacal. Revista Brasileira de Ciência do Solo, v.26, p.663-671, 2002.

WEISS, W.P.; CONRAD, H.R.; PIERRE, N.R.S. A theoretically-based model for predicting total digestible nutrient values of forages and concentrates. Animal Feed Science and Technology, v.39, p.95-110, 1992.

WERNER, J.C. Estudo de épocas da adubação nitrogenada em Capim colonião (Panicum maximum Jacq.) para aumento de produção de forragem nas secas. Boletim de Industria Animal, v. 27/28, p.361-367. 1970/71

WERNER, J.C.; PEDREIRA, J.V.S.; CAIELLI. E.L. Estudos de parcelamento e níveis de adubação em capim pangola. Boletim de Indústria Animal, v.24, p.147-151, 1967. 
WILES, P.G.; GRAY, I.K.; KISSLING, R.C. Routine analysis of protein by Kjeldal and Dumas methods: review and interlaboratory study using dairy products. Journal of AOAC International, v.81, n.3, p.620-632, 1998.

ZIMMER, H.A.; MACEDO, M.C.M.; BARCELLOS, A.O., KICHEL; A.N. Estabelecimento e recuperação de pastagens de Brachiaria. In: SIMPOSIO SOBRE MANEJO DE PASTAGEM, 11, Piracicaba, 1994. Anais. Piracicaba: Fealq, p.153-208. 